Historic, archived document

Do not assume content reflects current scientific knowledge, policies, or practices. 



\section{Preliminary Classification of Forest Vegetation of the Kenai Peninsula, Alaska}

选运

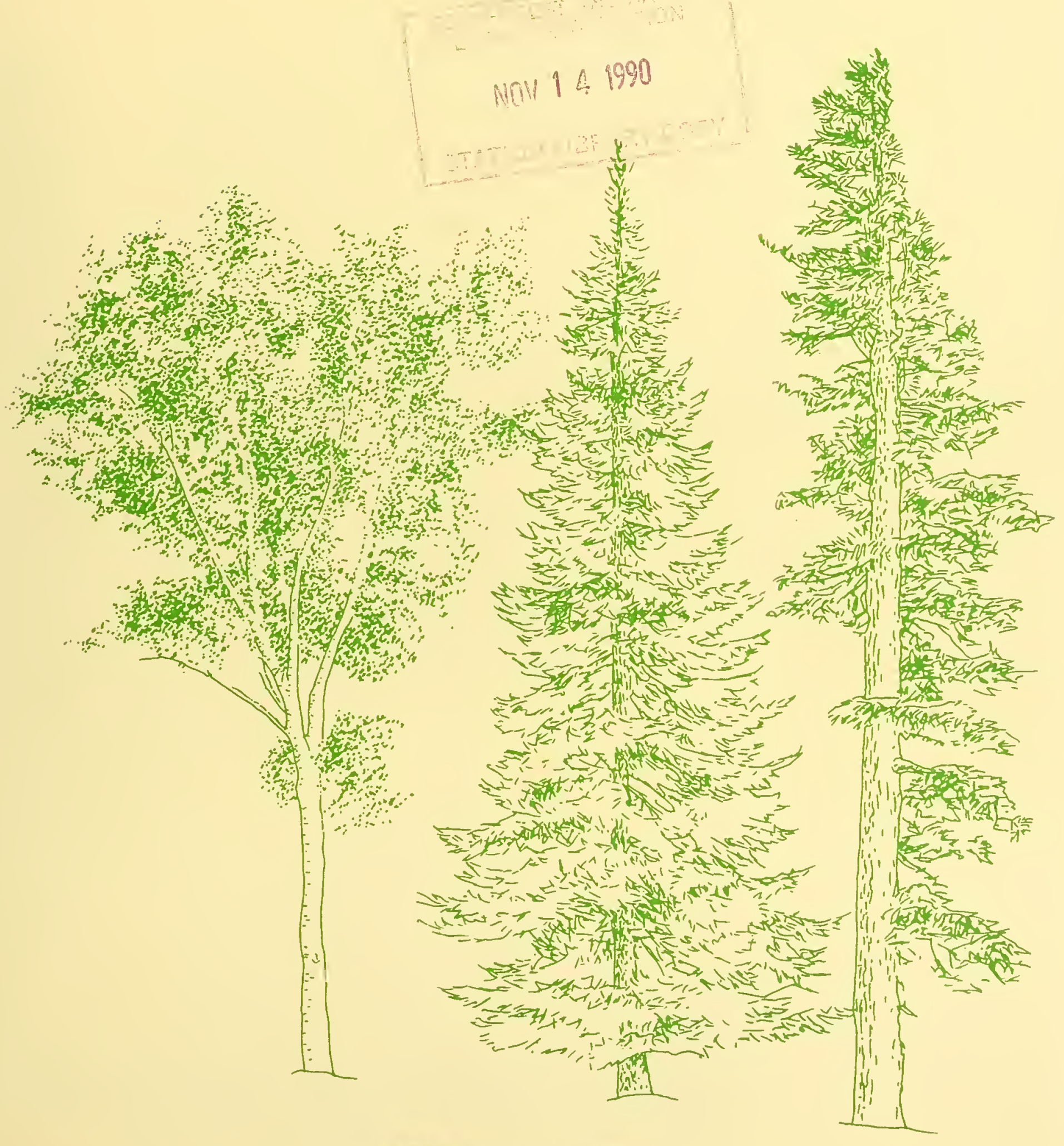



201 East Ninth Avenue, Suite 206, Anchorage, Alaska 99501. 
Abstract

Summary
Reynolds, K.M. 1990. Preliminary classification of forest vegetation of the Kenai Peninsula, Alaska. Res. Pap. PNW-RP-424. Portland, OR: U.S. Department of Agriculture, Forest Service, Pacific Northwest Research Station. 67 p.

A total of 5,597 photo points was systematically located on 1:60,000-scale highaltitude photographs of the Kenai Peninsula, Alaska; photo interpretation was used to classify the vegetation at each grid position. Of the total grid points, 12.3 percent were classified as timberland; 129 photo points within the timberland class were randomly selected for field survey. The number of sample points visited in each of three forest cover types (conifer, broadleaf, and mixed conifer-broadleaf) was proportional to the frequency of the cover type in the photo sample. Two-way indicator species analysis (TWINSPAN) was used to develop a hierarchical classification of the forest communities observed on the peninsula. Brief descriptions are presented for the 11 recognized communities with a discussion of their relation to basic physiographic and edaphic characteristics.

Keywords: Vegetation classification, Kenai Peninsula, Alaska.

The PNW Forest Inventory and Analysis Research Work Unit (Anchorage) systematically located 5,597 photo points on 1:60,000-scale high-altitude photographs of the Kenai Peninsula, Alaska. Photo interpretation was used to classify the vegetation at each grid position. Of the total grid points, 12.3 percent were classified as timberland; 129 photo points within the timberland class were randomly selected for field survey.

The number of sample points visited in each of three forest cover types (conifer, broadleaf, and mixed conifer-broadleaf) was proportional to the frequency of the cover type in the photo sample.

Cover data for the stand overstory were collected using a five-point pattern of variable-radius subplots at each sampling location. Sapling cover was estimated from five subplots, 1.5 meters in radius, centered on the variable-radius subplots; cover data for other understory layers were obtained from two subplots, 5.64 meters in radius. Elevation, slope, aspect, topographic position, and basic edaphic characteristics were determined for each plot. Two-way indicator species analysis (TWINSPAN) was used to develop a hierarchical classification of the observed forest communities.

The following six communities were all relatively homogeneous in physiographic and edaphic characteristics:

(1) Closed Picea mariana/Cornus canadensis-Vaccinium vitis-idaea/Peltigera spp.-Rhytidiadelphus spp.;

(2) Open Picea glauca-Picea mariana/Empetrum nigrum-Vaccinium vitis-idaea/ Peltigera spp.-Pleurozium spp.;

(3) Closed Picea glauca-Betula papyrifera/Cornus canadensis-Vaccinium vitis-idaea/ Epilobium spp./Pleurozium spp.;

(4) Closed Picea $\times$ lutzii-Betula papyrifera/Menziesia ferruginea-Rubus pedatus/ Gymnocarpium dryopteris/Peltigera spp.-Pleurozium spp.;

(5) Closed Picea glauca-Betula papyrifera/Menziesia ferruginea-Rubus pedatus/ Gymnocarpium dryopteris/Lycopodium spp.-Pleurozium spp., and;

(6) Closed Picea glauca-Picea $\times$ lutzii/Linnea borealis-Rubus pedatus/Sanguisorba spp.-Calamagrostis spp./Lycopodium spp.-Ptilium spp. 
Within the above group of communities, the fifth was relatively distinctive, with about 70 percent of plots occurring on sandy loam or coarser textured soils. All other communities occurred on finer textured soils with much higher frequency. Most of these communities occurred at low to medium elevations, in low- to mid-slope topographic positions, and with no single aspect predominating, although westerly aspects were slightly more common. Thickness of surface layers of moss and organic matter and of the rooting zone were fairly uniform within these communities. The decomposed organic layer was least developed in the sixth group. Poor drainage, as indicated either by presence of a shallow impermeable layer or by saturated soil was uncommon. The community characterized as Closed Picea $\times$ lutzii/Rubus pedatus-Salix spp./Sanguisorba spp.-Calamagrostis spp./Mnium spp. was similar to the above six communities in most respects but generally occurred at much higher elevations.

The closely related communities, Closed Picea $\times$ lutzii-Tsuga mertensiana/Cornus canadensis-Menziesia ferruginea/Sphagnum spp., and Closed Picea $\times$ lutziiTsuga mertensiana/Menziesia ferruginea-Oplopanax horridum/Dryopteris dilatata/ Rhytidiadelphus spp.-Sphagnum spp., occur at medium to high elevations, on steep slopes, and in mid-slope positions. These two communities occur predominantly on north and south slopes, respectively. Thickness of the surface organic layers and rooting zone is greater in these communities than in the first six, but this latter set of communities had the highest occurrence of saturated soils within 50 centimeters of the soil surface. Soil textures were predominantly silt loams and loams.

The community, Closed Picea sitchensis/Oplopanax horridum-Rubus pedatus/ Dryopteris dilatata-Gymnocarpium dryopteris/Mnium spp.-Rhytidiadelphus spp., occurs in or near the coastal climatic zone. It typically occurs on westerly aspects at low to medium elevations and on moderately steep slopes.

The riparian community, Open Picea $\times$ lutzii-Populus trichocarpa Alnus spp.Oplopanax horridum/Dryopteris dilatata, occurs across a broad elevational range. The rooting zone is relatively thick, and surface organic layers are strongly developed. The highest incidence of stands with an impervious layer occurred in this community. 
1 Introduction

1 Geography and Geology

1 Climate

3 Flora

3 Materials and Methods

3 Selecting Sample Stands and Subplots

$4 \quad$ Measuring Site Variables

4 Measuring Plant Cover

5 Plant identification

5 Vegetation Classification

8 Results and Discussion

17 Physiographic Characteristics of the Communities

17 Basic Edaphic Characteristics of the Communities

18 Stand Structure and Species Composition of the Communities

24 Conclusions

24 Acknowledgments

$24 \quad$ Literature Cited

$27 \quad$ Appendix 



\section{Introduction}

Geography and Geology
The Kenai Peninsula is in south-central Alaska and is bordered on the west by Cook Inlet and on the east by Prince William Sound (fig. 1). The total land area is about 21,104 square kilometers ${ }^{1}$ and is composed of two geographically distinct regions, the Kenai Mountains and the Kenai Lowlands (Martin and others 1915).

The Kenai Mountains cover about two-thirds of the total area and include the southern and eastern portions of the peninsula, which are divided from the western lowland area by an imaginary line from the head of Kachemak Bay in the southwest to the head of Chickaloon Bay in the north (fig. 1). Parent materials in the Kenai Mountains are composed primarily of slightly to moderately metamorphosed sedimentary series laid down from the Middle Jurassic to the Late Cretaceous. Some interbedding with mafic igneous intrusions also occurs. The mountains are over 2000 meters in elevation and formed as a result of major uplifting in the Late Cretaceous. ${ }^{2}$ The rugged relief of the Kenai Mountains, which is characterized by steep, narrow valleys, is due to glaciation and, to a lesser extent, stream cutting that followed uplifting (Martin and others 1915, Pewe 1975).

The Kenai Lowlands range from 15 to 60 meters in elevation and are composed of two discernible subregions. Immediately west of the mountain region, present lowland topography is the result of the formation of glacial moraines. Further west toward the coast, parent materials consist of silt-rich deposits laid down after the formation of glacially dammed lakes.

Climate

Climatic regimes on the Kenai Peninsula range from cool maritime along much of the coast to continental in interior portions (Selkregg 1974). These climatic zones are separated by a relatively narrow climatic transition zone. Approximate average daily minimum and maximum January temperatures for the peninsula are $-13^{\circ} \mathrm{C}$ and $-2{ }^{\circ} \mathrm{C}$, respectively; average daily minimum and maximum July temperatures are $5{ }^{\circ} \mathrm{C}$ and $16^{\circ} \mathrm{C}$, respectively. The peninsula is generally free of permafrost but scattered pockets occur, primarily in muskeg sites dominated by black spruce (Picea mariana (Mill.) B.S.P.) in the Kenai Lowlands. Temperature differences can conveniently be summarized for the Kenai Peninsula as a whole, but considerable variation in snowfall and precipitation occur between the mountain and lowland regions. The mountain region receives about 5 to 10 meters of total precipitation annually, of which 1.5 to 4 meters are snowfall. The lowland receives about 1.7 to 2.5 meters of total precipitation annually (including 0.5 meters of snowfall).

\footnotetext{
${ }^{1}$ Personal communication, November 11, 1988, Fred R. Larson, research forester, Pacific Northwest Research Station, Forestry Sciences Laboratory, 201 East Ninth Avenue, Suite 303, Anchorage, Alaska 99501.

${ }^{2}$ Hoekzema, Bob. 1979. Minerals task force draft working report on the Chugach National Forest. On file with: Forest Supervisor, Chugach National Forest, 201 East Ninth Avenue, Suite 2C6, Anchorage, Alaska 99501
} 


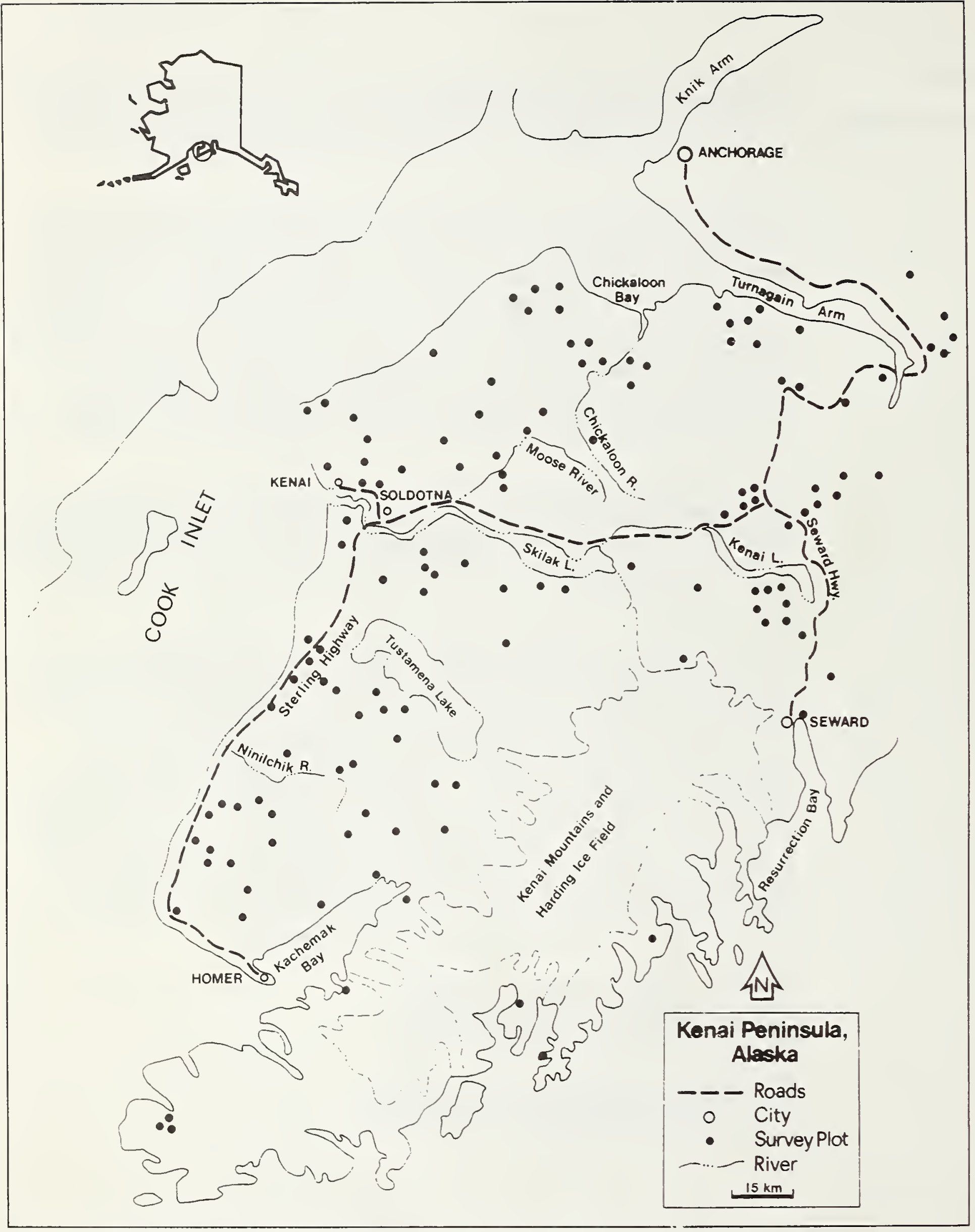

Figure 1-Location of field plots included in inventory survey. 
Flora

\section{Materials and Methods}

Selecting Sample Stands and Subplots
The vegetation of the Kenai Peninsula is characteristic of the Coniferous Forest Biome. Situated along the south-central coast of Alaska, the Kenai subregion is on the boundary of the southern boreal forest and coastal biogeoclimatic regions (Pojar and others 1987, Rowe 1972). Viereck and Dyrness (1980) published a preliminary report on a State-wide system for a hierarchical classification of plant communities, in which forest types and communities are distinguished at levels IV and $V$ of the hierarchy, respectively. Although some communities described by Viereck and Dyrness (1980) for southeast coastal and interior Alaska are represented on the Kenai Peninsula, the rugged relief of this area and its geographic position combine to produce a relatively unique mosaic of forest communities. Nineteen forest types are described for the Susitna River Basin (USDA Soil Conservation Service 1986), which lies on the north end of Cook Inlet and directly north of the Kenai Peninsula; however, a detailed analysis of forest community composition is not given. The present study provided a preliminary classification of the forest communities found in timberland on the Kenai Peninsula.

In 1987, scientists at the Forestry Sciences Laboratory in Anchorage, Alaska, conducted a timber inventory on the Kenai Peninsula by using a two-stage sampling design. A total of 5,597 photo points was systematically located on 1:60,000-scale high-altitude photographs by using a 3.19 - by 2.84 -centimeter grid. Photo interpretation was used to classify the vegetation at each grid position. The vegetation analysis was limited to a study of timberland (volume increment $>1.4$ cubic meters per hectare per year); 688 of the 5,597 points (12.3 percent) were classified as timberland. Stands classified as timberland were further classified by overstory cover type. A stand was classified as coniferous if overstory conifer cover was at least 75 percent, and similarly for broadleaf cover. If neither conifer nor broadleaf cover was at least 75 percent, then the stand was classified as mixed (conifer-broadleaf). Within the timberland class, 129 randomly selected photo points (18.7 percent of 688 timberland points) were selected for field survey, such that the number of sample points visited in each forest cover type was proportional to its frequency in the 5,597-point sample (number of points surveyed in coniferous, mixed, and broadleaf types was 82,40 , and 7 , respectively).

Stands surrounding each photo sample point were examined by using variable-radius plots typically arranged in a five-point pattern; the first subplot was centrally located, and subplot numbers two, three, four, and five were located 100 meters to the north, east, south, and west, respectively, of the central subplot. If subplot number two, three, four, or five fell within an area having vegetative cover not representative of the larger stand, the location of the subplot was shifted 100 meters to the east, south, west, or north, respectively.

For each plot, at least six of the largest stand dominants in or near the variableradius plots were selected as site trees to estimate stand age for inventory purposes. In mixed-species stands, at least two site trees were selected for each species represented in the stand overstory. For this study, only spruce (Picea spp.) species selected as site trees were used to compute stand age, so that stand age (as used here) refers only to the age of the spruce component of a stand. 
Plot elevation was recorded at the center of the first subplot in 30 -meter interval classes. Slope position, percent slope, and aspect were measured at each of the five subplot centers, and an average value obtained for the plot. Possible values for slope position of a plot were derived from four basic subplot values: "flat terrain", "midslope", "ridgetop", and "rolling terrain". An "average" value for slope position of a plot was obtained by applying two rules: If at least four of the five subplots were classified as having the same basic slope position value, then this slope position value was assigned to the whole plot. If less than four subplots were classified with the same basic slope position value, then an intermediate value of slope position was assigned. If, for example, there were two occurrences of "4lat terrain", and three occurrences of "midslope", then the plot would be classified as "lower slope." The complete set of basic and cierived values for slope position of a plot was: "flat terrain," "lower slope," "midslope," "upper slope," "ridgetop," and "rolling terrain."

Edaphic features recorded at each subplot were depth to the top of an impermeable layer, or saturated soil (if present) and depth to the bottom of the moss, fibrous organic matter, and decomposed organic matter layers. All values were recorded to the nearest centimeter. If neither an impermeable layer nor saturated soil was encountered within the top 50 centimeters of a soil profile, then a value of 99 centimeters was recorded. The five subplot values for each variable were averaged to obtain corresponding plot values.

Overstory-Overstory trees within each variable-radius plot were selected by using a prism with a basal area factor equal to four square meters per hectare. An individual was considered part of the overstory if tree diameter at breast height (d.b.h. at 137 centimeters) was at least 10 centimeters. Tree species, d.b.h., and crown radius were recorded for each sample tree. Percent cover by tree species within a subplot was calculated by summing the products of crown area for each tree and the number of individuals per hectare that a given tree represented. The five subplot values obtained for each tree species were averaged to estimate percent overstory cover of a tree species within the stand.

Saplings-Estimates of percent cover for saplings of each tree species (d.b.h. at least 2.5 centimeters and less than 10 centimeters) were obtained from five 1.5 -meter fixed-radius plots centered on the variable-radius timber plot centers. As with overstory trees, percent cover was calculated from the total crown area of the estimated number of saplings of a species per hectare. In the vegetation analyses described below, overstory and sapling cover were combined into a single cover estimate per species; this will be referred to as overstory cover. 
Plant identification

Vegetation Classification
Understory-Percent cover for mosses, lichens, forbs, grasses, shrubs, and tree reproduction (d.b.h. less than 2.5 centimeters) was based on average estimates from two 5.64-meter fixed-radius plots ( 0.01 hectares each) centered on the first two variable-radius timber plots. Because the original intent of the inventory in obtaining understory cover estimates was to characterize floristic composition in three dimensions, cover values for each species were separately estimated within several variable-height intervals up to 5 meters above the soil line. To use such data for describing the composition of the flora, it was necessary to express the percent cover of a species as its maximum cover value within the set of layers. In practical application, however, the only growth form with cover estimates expected to vary from standard estimation methods is tall shrubs. For tall shrubs, cover estimates used in this paper may slightly underestimate percent cover as usually estimated.

Hulten's (1968) treatment of Alaska flora was used for plant identification and as the source for taxonomic authorities for herbaceous vascular plants (table 1). Authorities for woody plants, mosses, and lichens were Viereck. and Little (1972), Crum and others (1973), and Hale and Culberson (1970), respectively. Trees were always identified to the species level. Grasses, mosses, and lichens were usually identified only to the generic level. Shrubs and forbs were not consistantly identified by field personnel to the species level. In preliminary tabulations of plant cover on a plot, whenever members of a genus were not consistantly identified to species level, cover values were summed to obtain a single cover estimate for the genus (table 1).

Sample stands were classified into forest communities with the computer program TWINSPAN (Hill 1979, Hill and others 1975). Gauch (1982) presents a good discussion of the TWINSPAN algorithm and its merits. Briefly, the TWINSPAN classification technique is a polythetic strategy, which means information on all species composing the stands-by-species matrix is used in the analysis. The TWINSPAN algorithm is hierarchical and divisive, meaning that the procedure starts by considering all stands as a single group. The program uses a slight modification of the reciprocal averaging algorithm (Hill 1973) as a basis for making successive dichotomous divisions on a set of sample stands. The TWINSPAN algorithm is used as follows (Gauch 1982):

1. Ordinate the sample stands using reciprocal averaging.

2. Refine the ordination by weighting the species such that those characteristic of the axis extremes are given greatest weight.

3. Divide the ordination axis near its origin such that species fidelity to membership in one of the two subsets is maximized.

4. Repeat steps 1-3 on the resulting subsets of stands. 
Overstory:

Betula papyrifera Marsh.

Picea glauca (Moench) Voss

Picea X lutzii Little

Picea mariana (Mill.) B.S.P.

Picea sitchensis (Bong.) Carr.

Populus tremuloides Michx.

Populus trichocarpa Torr. \& Gray.

Tsuga mertensiana (Bong.) Sarg.

Shrubs:

Alnus Mill.

Arctostaphylos uva-ursi (L.) Spreng.

Betula nana L.

Cornus canadensis L.

Cornus stolonifera Michx.

Cornus suecica L.

Empetrum nigrum L.

Ledum groenlandicum Oeder

Ledum palustre decumbens (Ait.) Hult.

Linnaea borealis L.

Menziesia ferruginea $\mathrm{Sm}$.

Oplopanax horridum

Ribes L.

Rosa acicularis Lindl.

Rubus L.

Rubus pedatus $\mathrm{Sm}$.

Salix L.

Sambucus racemosa L.

Shepherdia canadensis (L.) Nutt.

Sorbus S.F. Gray

Spiraea beauverdiana Schneid.

Vaccinium L.

Vaccinium vitis-idaea L.

Viburnum edule (Michx.) Raf.

Forbs:

Achillea borealis Bong.

Aconitum delphinifolium DC.

Actaea rubra (Ait.) Willd.

Anemone L.

Aquilegia formosa Fisch.

Aruncus sylvester Kostel.

Athyrium filix-femina (L.) Roth

Caltha L.

Castilleja unalaschcensis (Cham. \& Schlecht.) Malte

Circaea alpina L.

Dryopteris dilatata (Hoffm.) Gray

Epilobium L.

Equisetum L.

Galium L.

Gentiana anarella L.

Geocaulon lividum (Richards.) Fern.

Geranium erianthum DC.

Gymnocarpium dryopteris (L.) Newm.

Listera cordata (L.) R. Br.

Lupinus L.

Moneses uniflora (L.) Gray

Pedicularis labradorica Wirsing

Polemonium L.

Polystichum braunii (Spenn.) Fee

Potentilla L.

Paper birch

White spruce

Lutz spruce

Black spruce

Sitka spruce

Trembling aspen

Black cottonwood

Mountain hemlock

Alder

Bearberry

Dwarf arctic birch 12

Bunchberry 105

American dogwood

Swedish dwarf cornel

Black crowberry

Labrador tea

Northern Labrador tea

Twin flower

Rusty menziesia

Devil's club

Currant

Prickly rose

Raspberry

Five-leaf bramble

Willow

Red elderberry

Buffaloberry

Mountain ash

Beauverd spirea

Blueberry

Lowbush cranberry

Highbush cranberry

Common yarrow

Monkshood

Baneberry

Anemone

Columbine

Goatsbeard

Lady fern

Marsh marigold

Yellow painbrush

Enchanted nightshade Spinulose shield fern Willow-herb

Horsetail

Bedstraw

Gentian

Northern commandra

Northern geranium

Oak-fern

Heart twyblade

Lupine

Single delight

Labrador lousewort

Jacob's ladder

Prickly shield fern

Cinquefoil 


\begin{tabular}{|c|c|c|}
\hline Scientific name ${ }^{a}$ & Common name & Incidence \\
\hline & & Number ${ }^{b}$ \\
\hline \multicolumn{3}{|l|}{ Forbs: } \\
\hline Pyrola L. & Wintergreen & 46 \\
\hline Sanguisorba L. & Burnet & 34 \\
\hline Smilacina Desf. & Solomon seal & 1 \\
\hline Stellaria L. & Chickweed & 1 \\
\hline Streptopus Michx. & Twisted stalk & 33 \\
\hline Thelypteris phegopteris (L.) Slosson & Beech fern & 4 \\
\hline Tiarella trifoliata L. & Three leaf lace flower & 7 \\
\hline Trientalis europaea L. & Starflower & 40 \\
\hline Veratrum viride Ait. & False hellebore & 6 \\
\hline Viola L. & Violet & 2 \\
\hline \multicolumn{3}{|l|}{ Grasses: } \\
\hline Calamagrostis Adans. & Reed bentgrass & 61 \\
\hline Carex L. & Sedge & 4 \\
\hline \multicolumn{3}{|l|}{ Mosses and lichens: } \\
\hline Alectoria sp. & Lichen & 26 \\
\hline Aulacomnium sp. & Bog moss & 42 \\
\hline Cetraria sp. & Lichen & 2 \\
\hline Cladina sp. & Lichen & 15 \\
\hline Cladonia sp. & Lichen & 37 \\
\hline Dicranum sp. & Moss & 63 \\
\hline Drepanocladus sp. & Moss & 2 \\
\hline Hepaticae & Liverwort & 12 \\
\hline Hylocomium sp. & Feathermoss & 121 \\
\hline Hypnum sp. & Moss & 9 \\
\hline Hypogmnia sp. & Lichen & 39 \\
\hline Lobaria sp. & Lichen & 8 \\
\hline Lycopodium sp. & Clubmoss & 88 \\
\hline Mnium sp. & Moss & 58 \\
\hline Nephroma sp. & Lichen & 25 \\
\hline Parmelia sp. & Lichen & 6 \\
\hline Peltigera sp. & Veined lichen & 80 \\
\hline Pleurozium schreberi (Brid.) Mitt. & Schreber's moss & 100 \\
\hline Polytrichum sp. & Moss & 81 \\
\hline Ptilium sp. & Plume moss & 70 \\
\hline Rhytidiadelphus sp. & Moss & 64 \\
\hline Sphagnum sp. & Sphagnum moss & 55 \\
\hline Stereocaulon sp. & Lichen & 3 \\
\hline Usnea sp. & Lichen & 41 \\
\hline
\end{tabular}

a Absence of a species name indicates that plant specimens were not identified to species on at least 1 plot and that all such species were combined at the generic level for analysis.

b Number of inventory plots in which a genus or species was observed.

In my analysis, a maximum oi five levels of division were specified. Division on a subset of stands was terminated if a subset contained less than six stands. The default cut points of TWINSPAN for defining cover classes (for example, 0, 2, 5, 10, and 20 percent cover) were used so that the classification of plots would not be too heavily influenced by oversiory composition. The species composition of each pair of subsets at the lowest level or division was compared by using the ordered species-by-stands matrix producec by TWINSPAN; low-level divisions were eliminated when distinctions in species composition were trivial. Names for vegetation communities were constructed from the names of species (or genera) both dominant and characteristic in each of the four vegetation layers (for example, tree, shrub, forb-grass, and lichenmoss layers). No distinction was made between low- and tall-shrub layers, and mosses and lichens were treated as a single vegetation layer. 
Results and Discussion
A diagram of the results of the TWINSPAN analysis shows the forest communities that could be usefully distinguished and the relations of these communities to each other in the hierarchical classification (fig. 2). The names of the forest communities that correspond to the numerical designations for TWINSPAN subsets (TSS) are given in table 2. Communities will generally be referred by the TSS designations (for example, TSS *0000). Average species cover and constancy values by community are presented in tables 3 and 4, respectively. Average total cover by vegetation layer within a community is summarized in table 5. General site and stand attributes of the plots included in each community are summarized in table 6 . Cover values reported for stand overstories as reported in table 5 were not used as a basis for the overstory cover classes in table 6 . Percent overstory cover in table 5 includes both trees classified as growing stock (d.b.h. at least 10.0 centimeters) and saplings. Cover classes in table 6 are based on percent cover of overstory trees only. Basic edaphic features of the forest communities are summarized in table 7.

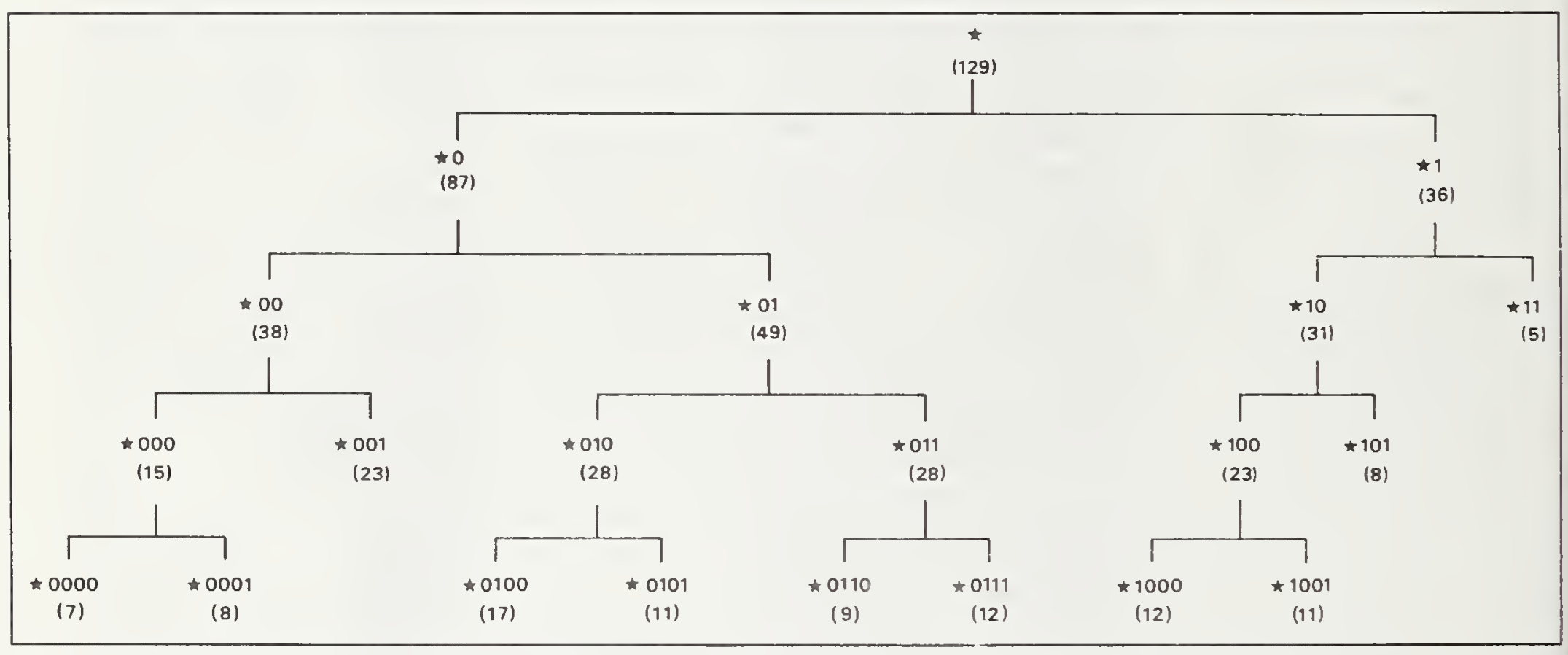

Figure 2 -Hierarchical classification of forest communities produced by the program TWINSPAN. The correspondence between community names and TWINSPAN subset designations is presented in table 2. Individual plots included in a particular community are delineated in the appendix.

8 


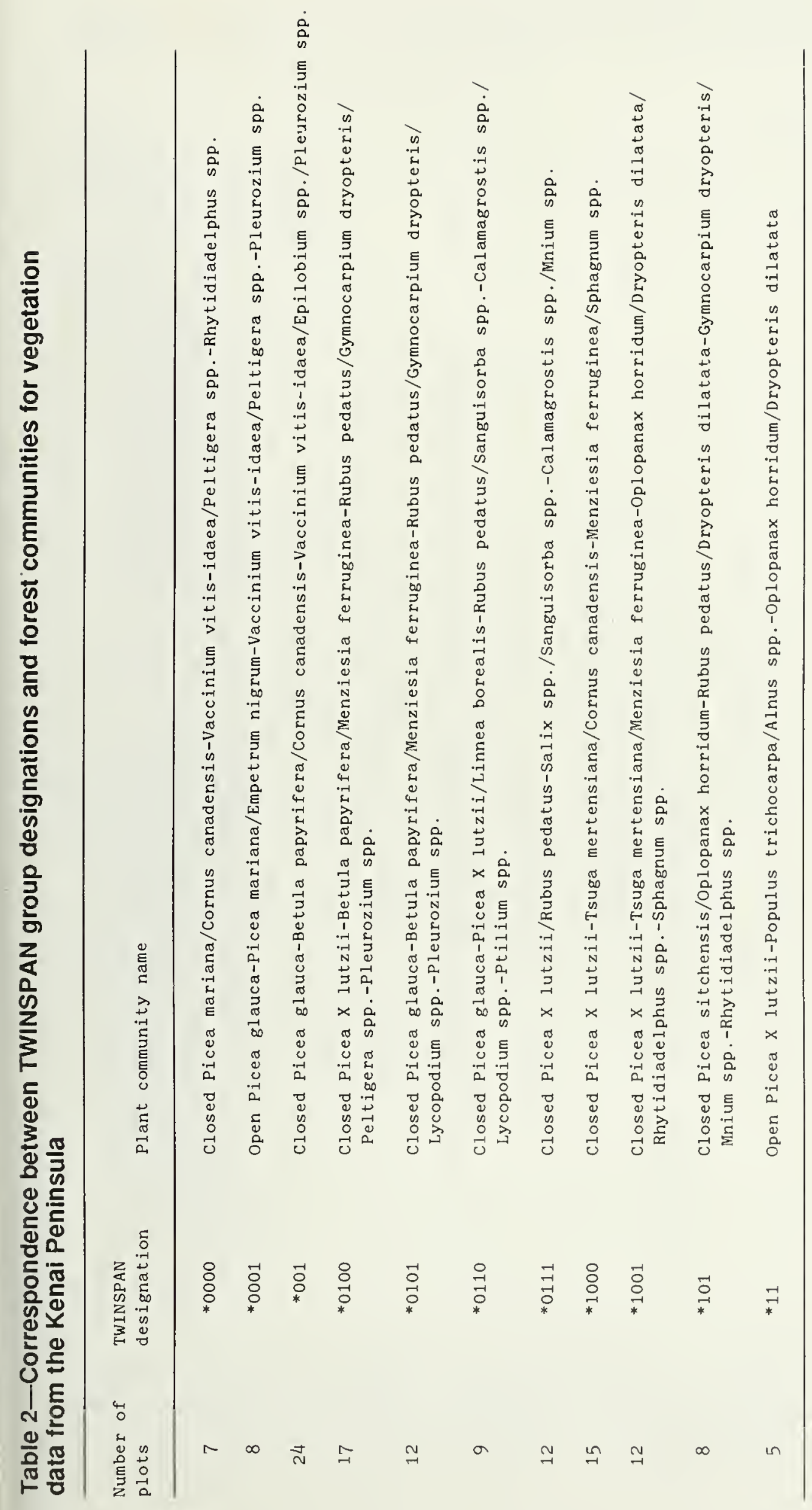




\begin{tabular}{|c|c|c|c|c|c|c|c|c|c|c|c|}
\hline \multirow[b]{2}{*}{ Species } & \multicolumn{11}{|c|}{ TWINSPAN forest community designation ${ }^{b}$} \\
\hline & $* 0000$ & *0001 & *001 & *0100 & *0101 & *0110 & *0111 & *1000 & *1001 & *101 & $* 11$ \\
\hline & \multicolumn{11}{|c|}{ Percent cover $^{c}$} \\
\hline Overstory: & & & & & & & & & & & \\
\hline Betula papyrifera & 20.6 & $17 \cdot 7$ & 45.4 & 25.9 & 51.1 & 26.2 & 4.5 & 10.4 & 4.5 & . & 1.2 \\
\hline Picea glauca & 14.9 & $37 \cdot 5$ & 35.6 & 10.2 & 30.1 & 34.4 & 24.0 & 1.4 & & $\mathrm{Tr}$ & 11.1 \\
\hline Picea X lutzii & 16.6 & $\cdot$ & 22.8 & 52.3 & 21.2 & 35.3 & 66.6 & 36.2 & 56.1 & 25.4 & 33.2 \\
\hline Picea mariana & 44.4 & 44.2 & 8.1 & 1.9 & 3.0 & & . & $\operatorname{Tr}$ & & . & . \\
\hline Picea sitchensis & & • & • & $\cdot$ & . & 8.2 & . & 3.4 & 1.2 & $52 \cdot 3$ & 3.2 \\
\hline Populus tremuloides & 18.9 & 1.3 & 19.7 & 4.3 & .1 & 4.5 & . & . & . & . & . \\
\hline Populus trichocarpa & . & . & 2.0 & 0.3 & 2.4 & . & . & • & . & . & 18.6 \\
\hline Tsuga mertensiana & . & . & $\cdot$ & 11.5 & • & . & $\operatorname{Tr}$ & 68.5 & 47.2 & 10.6 & 6.8 \\
\hline \multicolumn{12}{|l|}{ Understory: } \\
\hline Betula papyrifera & .4 & .5 & .7 & .1 & .2 & 1.7 & 2.2 & .1 & .1 & . & . \\
\hline Picea glauca & 1.0 & .7 & 2.3 & $\cdot 3$ & 1.0 & .4 & .2 & .1 & . & . & . \\
\hline Picea X lutzii & • & $\cdot$ & .9 & .3 & . & .9 & 2.6 & 1.1 & . & .6 & . \\
\hline Picea mariana & 14.9 & 6.2 & .7 & $\cdot$ & . & . & . & . & . & . & . \\
\hline Picea sitchensis & • & . & · & . & . & . & . & .3 & .1 & .6 & - \\
\hline Populus tremuloides & .4 & . & .3 & . & . & . & . & · & $\cdot$ & . & . \\
\hline Populus trichocarpa & . & . & $\cdot$ & · & . & . & . & . & $\cdot$ & . & \\
\hline Tsuga mertensiana & . & . & . & $3 \cdot 9$ & . & . & . & 10.5 & 1.8 & 1.1 & . \\
\hline \multicolumn{12}{|l|}{ Shrubs: } \\
\hline Alnus spp. & . & .6 & $\operatorname{Tr}$ & 1.2 & 7.1 & . & 2.2 & 1.8 & 7.4 & 1.2 & 29.2 \\
\hline Arctostaphylos uva-ursi & . & .2 & $\cdot$ & . & . & $\cdot$ & . & . & . & . & . \\
\hline Betula nana & $2 \cdot 3$ & 1.1 & .6 & .2 & . & .8 & .2 & . & . & . & . \\
\hline Cornus canadensis & 3.7 & 5.6 & 8.0 & $5 \cdot 3$ & 5.8 & 3.9 & 2.8 & $3 \cdot 5$ & 2.2 & 1.4 & . \\
\hline Cornus stolonifera & . & . & . & . & .2 & $\cdot$ & . & . & . & . & . \\
\hline Cornus suecica & . & 1.4 & 1.4 & 1.3 & 2.7 & .8 & 1.7 & .8 & . & .1 & . \\
\hline Empetrum nigrum & 11.1 & 11.1 & 1.5 & 4.7 & . & 2.0 & 2.5 & 2.9 & . & . & . \\
\hline Ledum groenlandicum & 1.0 & .6 & .9 & $\cdot 3$ & . & . & .2 & . & . & . & . \\
\hline Ledum palustre decumbens & . & 3.4 & $\cdot$ & : & • & $\cdot$ & . & . & . & . & . \\
\hline Linnaea borealis & 3.7 & 2.9 & 6.5 & $5 \cdot 5$ & $5 \cdot 3$ & 8.0 & 4.5 & 1.7 & .1 & .1 & .8 \\
\hline Menziesia ferruginea & . & 10.6 & $\mathrm{Tr}$ & 19.5 & 21.1 & .7 & 3.3 & 13.1 & 12.5 & 2.2 & .2 \\
\hline Oplopanax horridum & . & . & .1 & . & 2.0 & . & .1 & .2 & 6.1 & 17.0 & 19.4 \\
\hline Ribes spp. & . & .7 & .1 & .3 & .2 & 1.3 & .7 & .1 & .5 & . & 1.6 \\
\hline Rosa acicularis & 1.3 & 1.1 & 2.5 & .8 & 2.0 & & .1 & . & $\cdot$ & . & . \\
\hline Rubus pedatus & $\cdot$ & . & $\cdot$ & 8.4 & 8.8 & 16.1 & 14.5 & $3 \cdot 3$ & 8.1 & 18.5 & 4.4 \\
\hline Other Rubus spp. & .6 & 2.5 & 1.0 & .8 & $\cdot 3$ & 1.1 & 2.4 & .2 & .1 & .7 & . \\
\hline Salix spp. & 1.0 & 4.5 & 2.5 & 1.0 & .1 & 4.2 & 6.0 & .4 & .1 & . & . \\
\hline Sambucus racemosa & . & . & . & . & 1.0 & .1 & . & . & .2 & .1 & 2.4 \\
\hline Shepherdia canadensis & . & . & .6 & . & . & . & . & . & . & . & - \\
\hline Sorbus spp. & . & . & $\operatorname{Tr}$ & .3 & .2 & . & .2 & .3 & .2 & . & . \\
\hline Spiraea spp. & 2.6 & 2.0 & .4 & 2.1 & .2 & 2.8 & $3 \cdot 5$ & . & - & . & . \\
\hline Vaccinium vitis-idaea & 26.3 & $17 \cdot 5$ & 19.8 & $7 \cdot 3$ & . & . & 3.7 & 1.7 & . & . & . \\
\hline Other Vaccinium spp. & 3.9 & 5.4 & 1.0 & .7 & 3.4 & 3.9 & 2.2 & 6.2 & 4.4 & 14.7 & . \\
\hline Viburnum edule & $\cdot$ & $\cdot$ & $2 \cdot 3$ & .5 & 3.7 & .9 & .1 & .5 & .1 & .1 & . \\
\hline \multicolumn{12}{|l|}{ Forbs: } \\
\hline Achillea spp. & . & . & .1 & . & - & .1 & $\cdot$ & . & . & . & . \\
\hline Aconitum delphinifolium & . & . & . & . & . & . & $\cdot 3$ & . & . & . & . \\
\hline Actaea rubra & . & . & $\operatorname{Tr}$ & . & . & . & .2 & . & .2 & . & . \\
\hline Anemone spp. & . & . & . & . & . & . & .6 & . & . & . & . \\
\hline Aquilegia spp. & . & . & . & . & . & . & .2 & . & . & . & . \\
\hline Aruncus sylvester & . & . & . & . & . & . & . & . & .1 & . & . \\
\hline Athyrium filix.femina & . & . & . & .1 & .1 & .2 & .6 & . & .5 & 2.6 & 1.2 \\
\hline Caltha spp. & . & . & . & . & . & . & . & . & . & .1 & . \\
\hline Castilleja unalaschcensis & . & . & . & . & . & . & .1 & . & . & . & . \\
\hline Circaea alpina & . & . & . & . & . & . & .2 & . & . & . & . \\
\hline Dryopteris dilatata & . & . & . & $1 \cdot 3$ & $5 \cdot 5$ & 6.1 & 2.7 & 1.0 & 6.2 & 15.2 & 20.4 \\
\hline Epilobium spp. & .7 & .7 & 2.8 & .7 & 1.3 & 2.9 & 1.9 & .3 & .2 & . & .6 \\
\hline Equise tum spp. & .1 & 2.5 & $\operatorname{Tr}$ & 4.8 & 3.7 & 1.7 & 9.7 & . & .2 & .1 & 3.2 \\
\hline
\end{tabular}

'see footnotes at end of table. 
TWINSPAN forest community designation ${ }^{b}$

Forbs :

Galium spp.

Gentiana amarella

Geocaulon 1ividum

Geranium erianthum

Gymnocarpium dryopteris

Listera cordata

Lupinus spp.

Moneses uniflora

Pedicularis labradorica

Polemonium spp.

Polystichum braunii

Potentilla spp.

Pyrola spp.

Sanguisorba spp.

Smilacina spp.

Stellaria spp.

Streptopus spp.

The1ypteris phegopteris

Tiare 11 a spp.

Trientalis europaea

Verat rum viride

Viola spp.

Grasses:

Calamagrostis spp.

Carex spp.

Mosses and lichens:

Alectoria spp.

Aulacomnium spp.

Cetraria spp.

Cladina spp.

Cladonia spp.

Dicranum spp.

Drepanocladus spp.

Hepaticae

Hylocomium spp.

Hypnum spp.

Hypogmnia spp.

Lobaria spp.

Lycopodium spp.

Mnium spp.

Nephroma spp.

other lichen

other moss

Parmelia spp.

Pe1tigera spp.

Pleurozium schreberi

Polytrichum spp.

Ptilium spp.

Rhytidiadelphus spp.

Sphagnum spp.

Usnea spp.
3

$$
1.0
$$

2.

$$
.9
$$

2.1

1.0

. $\quad .2 \quad$ Tr

$13.0 \quad 18.0 \quad 23.3$

$\begin{array}{lll}.4 & . & .2 \\ .4 & .2\end{array}$

.1$$
\cdot 1
$$

\begin{tabular}{l}
$-3.9 \quad 4.7$ \\
\hline
\end{tabular}

3.1

.3

2.3

4.0

4.0
19.9

19.9
3.4

$2 \cdot 3$

23.3

3. 4

\section{Percent cover ${ }^{c}$}

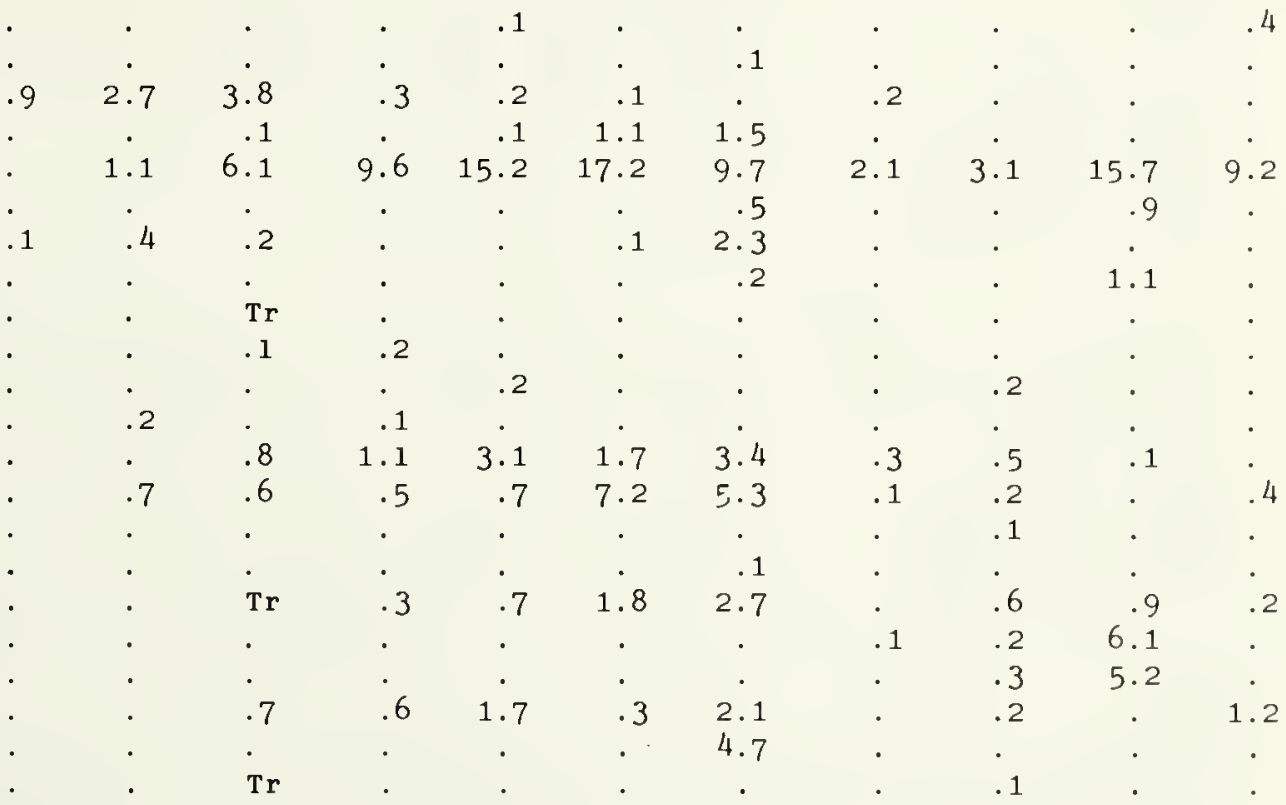

Tabulated values are summarized from tables $8 a-18 a$ in the appendix.

b Descriptive names for forest communities are presented in table 2.

c Tr indicates that a species was present in a given TWINSPAN group, but that its average cover value was

$<0.1$ percent. 
TWINSPAN forest community designation $b$

Overstory:

Betula papyrifera

Picea glauca

Picea X lutzii

Picea mariana

Picea sitchensis

Populus tremuloides

Populus trichocarpa

Tsuga mertensiana

Understory:

Betula papyrifera

Picea glauca

Picea X lutzii

Picea mariana

Picea sitchensis

Populus tremuloides

Populus trichocarpa

Tsuga mertensiana

Shrubs :

Alnus spp.

Arctostaphylos uva-ursi

Betula nana

Cornus canadensis

Cornus stolonifera

Cornus suecica

Empetrum nigrum

Ledum groenlandicum

Ledum palustre decumbens

Linnaea borealis

Menziesia ferruginea

Oplopanax horridum

Ribes spp.

Rosa acicularis

Rubus pedatus

Other Rubus spp.

Salix spp.

Sambucus racemosa

Shepherdia canadensis

Sorbus spp.

Spiraea spp.

Vaccinium vitis-idaea

Other Vaccinium spp.

Viburnum edule

Forbs:

Achillea spp.

Aconitum delphinifolium

Actaea rubra

Anemone spp.

Aquilegia spp.

Aruncus sylvester

Athyrium filix-femina

Caltha spp.

Castilleja unalaschcensis

Circaea alpina

Dryopteris dilatata

Epilobium spp.

Equisetum spp.

Constancy ${ }^{c}$

$\begin{array}{rrr}100 & 75 & 92 \\ 57 & 75 & 79 \\ 43 & - & 58 \\ 100 & 87 & 29 \\ - & - & - \\ 86 & 25 & 83 \\ - & - & 25 \\ - & - & -\end{array}$

82
41
88
18
-
12
6
35

100
83
33
8
-
17
17
-

100
44

48

33

13

87

7

13

-

10

33

100

25

100

92

$\begin{array}{rrr}14 & 25 & 33 \\ 29 & 37 & 46 \\ - & - & 12 \\ 100 & 62 & 21 \\ - & - & - \\ 29 & - & 12 \\ - & - & - \\ - & - & -\end{array}$

12
6
23
-
-
-
-
23

17
42
-
-
-
-
-
-

$\begin{array}{rr}33 & 17 \\ 11 & 17 \\ 44 & 58 \\ - & - \\ - & - \\ - & - \\ - & - \\ - & -\end{array}$

7
7
20
-
7
-
-
93

25
-
25
-
-
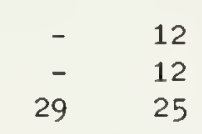

29

10

14

57

29

- 50

$57 \quad 75$

57
$-\quad 37$

- 25

$43 \quad 25$

14

14
43

$\begin{array}{lll}43 & 87 & 50\end{array}$

12
-
6
100
-
29
71
12
-
100
82
-
35
29
94
18
23
-
-
18
53
76
23
23

$$
\begin{array}{r}
50 \\
- \\
- \\
92 \\
17 \\
33 \\
- \\
- \\
- \\
92 \\
92 \\
33 \\
17 \\
58 \\
83 \\
17 \\
8 \\
25 \\
- \\
8 \\
17 \\
- \\
58 \\
75
\end{array}
$$$$
\begin{array}{r}
- \\
- \\
22 \\
78 \\
- \\
33 \\
33 \\
- \\
- \\
100 \\
11 \\
- \\
55 \\
- \\
100 \\
44 \\
33 \\
11 \\
- \\
- \\
67 \\
- \\
55 \\
22
\end{array}
$$

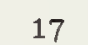

58

37

100

$$
\begin{array}{r}
- \\
17 \\
58 \\
- \\
33 \\
67 \\
8 \\
- \\
75 \\
33 \\
8 \\
50 \\
8 \\
100 \\
83 \\
92 \\
- \\
- \\
17 \\
67 \\
50 \\
83 \\
8
\end{array}
$$$$
93
$$$$
20
$$$$
33
$$$$
\text { - }
$$$$
60
$$$$
100
$$$$
\begin{array}{r}
13 \\
7
\end{array}
$$$$
\text { - }
$$$$
\begin{aligned}
& 7 \\
& 7
\end{aligned}
$$$$
\begin{array}{r}
7 \\
- \\
-
\end{array}
$$$$
\begin{array}{ll}
37 & 17
\end{array}
$$$$
\begin{array}{lll}
29 & 37 & 29
\end{array}
$$$$
\begin{array}{r}
20 \\
- \\
40 \\
67
\end{array}
$$

See footnotes at end of table. 
TWINSPAN forest community designation ${ }^{b}$

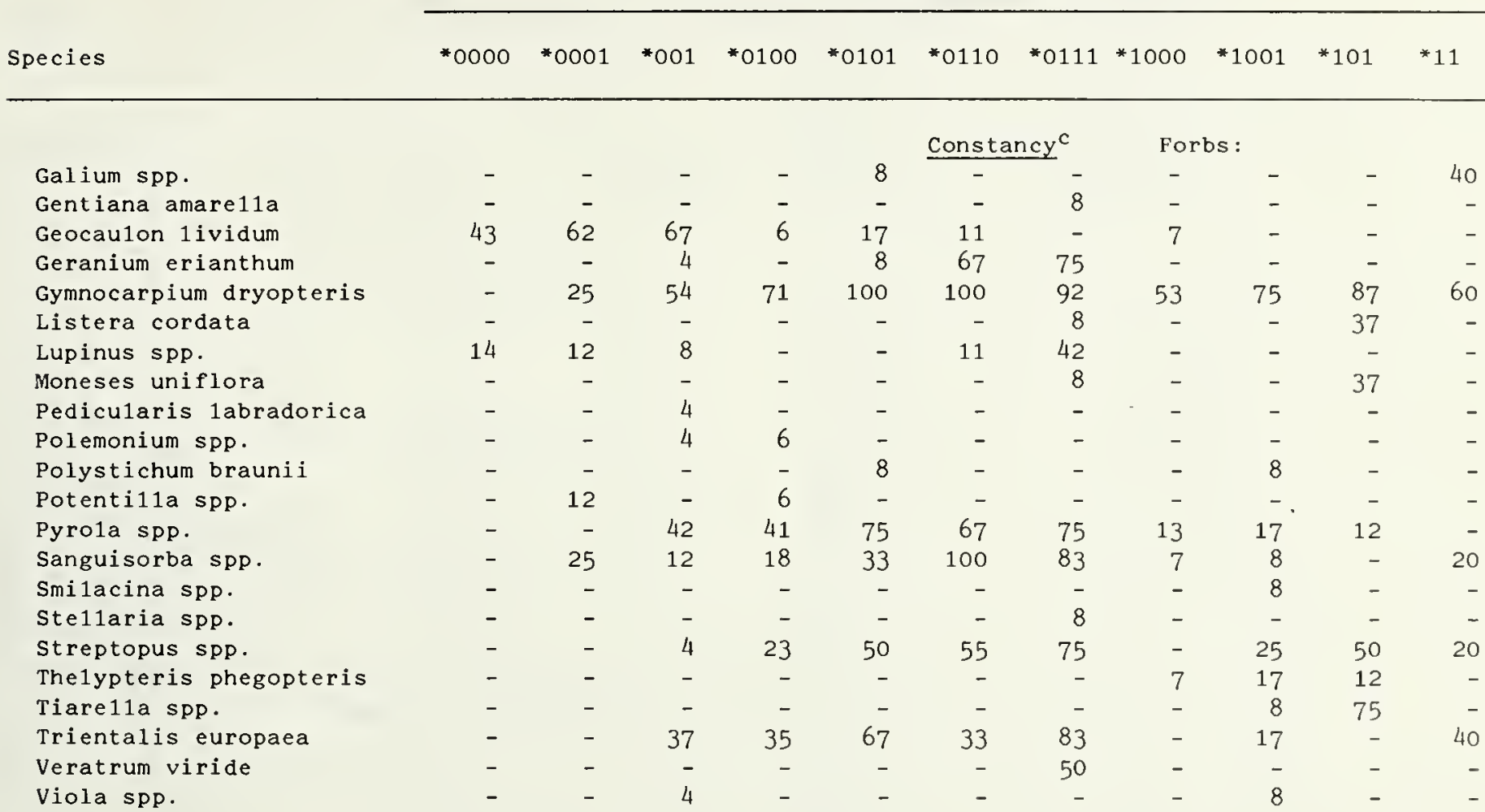

Grasses :

Calamagrostis spp.

Carex spp.

\section{4}

Mosses and 1ichens:

Alectoria spp.

Aulacomnium spp.

Cetraria spp.

C1adina spp.

Cladonia spp.

Dicranum spp.

Drepanocladus spp.

Hepaticae

Hylocomium spp.

Hypnum spp.

Hypogmnia spp.

Lobaria spp.

Lycopodium spp.

Mnium spp.

Nephroma spp.

Other 1ichen

Other moss

Parmelia spp.

Peltigera spp.

Pleurozium schreberi

Polytrichum spp.

Ptilium spp.

Rhytidiade1phus spp.

Sphagnum spp.

Usnea spp.
14

37

57
29

43

46
57

57

-

86

43

43
14

14

$-$

14

14

86

$-$

100

$57 \quad 100$

$86 \quad 62$

$57 \quad 12$

86

29
100

92
8

7

25

25

20

$\begin{array}{rr}12 & 12 \\ - & 25 \\ - & - \\ 50 & 8 \\ 12 & 21 \\ 25 & 17 \\ - & 4 \\ - & - \\ 100 & 100 \\ - & 12 \\ 37 & 17 \\ - & - \\ 62 & 71 \\ 12 & 8 \\ 50 & 8 \\ - & 25 \\ 37 & 71 \\ 12 & 8 \\ 87 & 87 \\ 100 & 92 \\ 62 & 79 \\ 12 & 67 \\ - & 25 \\ 50 & 25 \\ - & -\end{array}$

$\begin{array}{rr}44 & 25 \\ 44 & 42 \\ - & - \\ - & 17 \\ 11 & 17 \\ 67 & 50 \\ - & - \\ 22 & 8 \\ 100 & 92 \\ 22 & 8 \\ 44 & 42 \\ 11 & - \\ 89 & 75 \\ 78 & 100 \\ 33 & 42 \\ 11 & 25 \\ 33 & 92 \\ - & - \\ 55 & 83 \\ 78 & 83 \\ 67 & 75 \\ 100 & 25 \\ 67 & 33 \\ 11 & 58 \\ - & -\end{array}$

7
47
13
7
60
80
-
20
100
-
33
7
60
40
13
20
40
7
73
80
60
60
67
87
7$$
25
$$$$
33
$$$$
25
$$

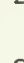$$
17
$$$$
75
$$$$
12
$$$$
75
$$$$
-
$$

$$
\begin{array}{r}
- \\
62 \\
37 \\
12 \\
87
\end{array}
$$$$
100
$$$$
\begin{aligned}
& 37 \\
& 12
\end{aligned}
$$$$
67 \quad 25
$$

a Tabulated values are summarized from tab1es $8 a-18 a$ in the appendix.

b Descriptive names for forest communities are presented in table 2.

c Tr indicates that a species was present in a given TWINSPAN group, but that its average cover value was

< 0.1 percent. A dash indicates complete absence of a species from a TWINSPAN group. 
Table 5-Average total species cover by forest community and canopy layer ${ }^{a}$

\begin{tabular}{|c|c|c|c|c|c|c|}
\hline \multirow[b]{2}{*}{$\begin{array}{l}\text { TWINSPAN } \\
\text { designation }{ }^{b}\end{array}$} & \multicolumn{6}{|c|}{ Average total cover } \\
\hline & Overstory ${ }^{c}$ & Reproduction & Shrub & Forbd & Moss & and lichen \\
\hline & \multicolumn{6}{|c|}{ Percent } \\
\hline *0000 & $115 \cdot 3$ & 16.7 & 57.6 & 3.0 & $\cdot$ & 80.1 \\
\hline *0001 & 99.5 & $7 \cdot 5$ & 71.4 & 5.0 & & 86.6 \\
\hline *001 & $133 \cdot 5$ & 4.8 & $49 \cdot 3$ & 15.6 & & 71.9 \\
\hline *0100 & 106.4 & 4.6 & 60.1 & 19.6 & & $77 \cdot 7$ \\
\hline *0101 & 107.8 & 1.2 & 64.2 & 32.7 & & 56.0 \\
\hline *0110 & 108.8 & 3.0 & 46.6 & 40.7 & & 74.0 \\
\hline *0111 & 95.0 & 3.0 & 49.7 & 49.2 & & 87.8 \\
\hline * 1000 & 119.9 & 11.9 & 36.7 & 4.1 & & $77 \cdot 9$ \\
\hline * 1001 & 109.0 & 2.0 & 41.9 & 12.6 & & 56.0 \\
\hline * 101 & 100.7 & 2.4 & 56.6 & 48.2 & & 84.0 \\
\hline * 11 & 74.0 & 0 & 58.0 & 36.8 & & 17.8 \\
\hline
\end{tabular}

a Cover values are summarized from tables $8 a-18 a$ in the appendix.

b Descriptive names for forest communities are presented in table 2 .

c Percent cover for overstory vegetation includes saplings.

d Percent grass cover is not included in forb cover.

Detailed descriptions of the 11 forest communities (fig. 2) are presented in the appendix (tables 8 through 18). The suffixes $a, b$, and $c$, used on appendix table numbers, identify tables for species composition, stand and site characteristics, and basic edaphic features, respectively, of each plot included in a particular community. Within some communities, considerable heterogeneity among plots included in a particular community is apparent in both composition of stand overstories (tables $8 \mathrm{a}$ to 18a) and other stand and site characteristics (tables $8 \mathrm{~b}$ to 18b). Because all vegetation layers had the potential to contribute more or less equally to the classification procedure by virtue of the default cut points noted previously, this heterogeneity was not unexpected. The intent in allowing understory species to assume weights comparable to those in the overstory was to delineate the communities more indicative of a site's vegetative cover potential, and not to relate understory structure to overstory structure. 


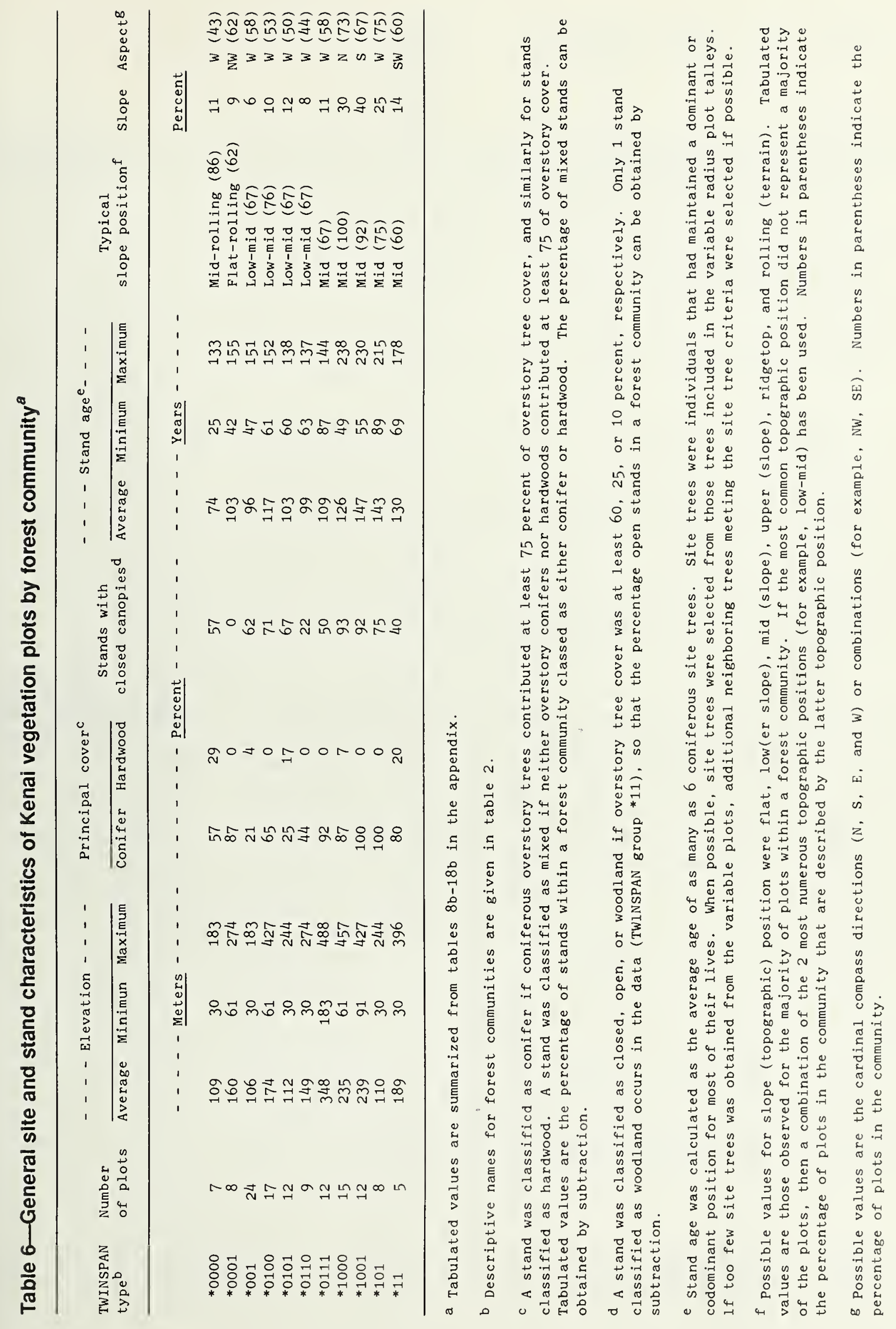




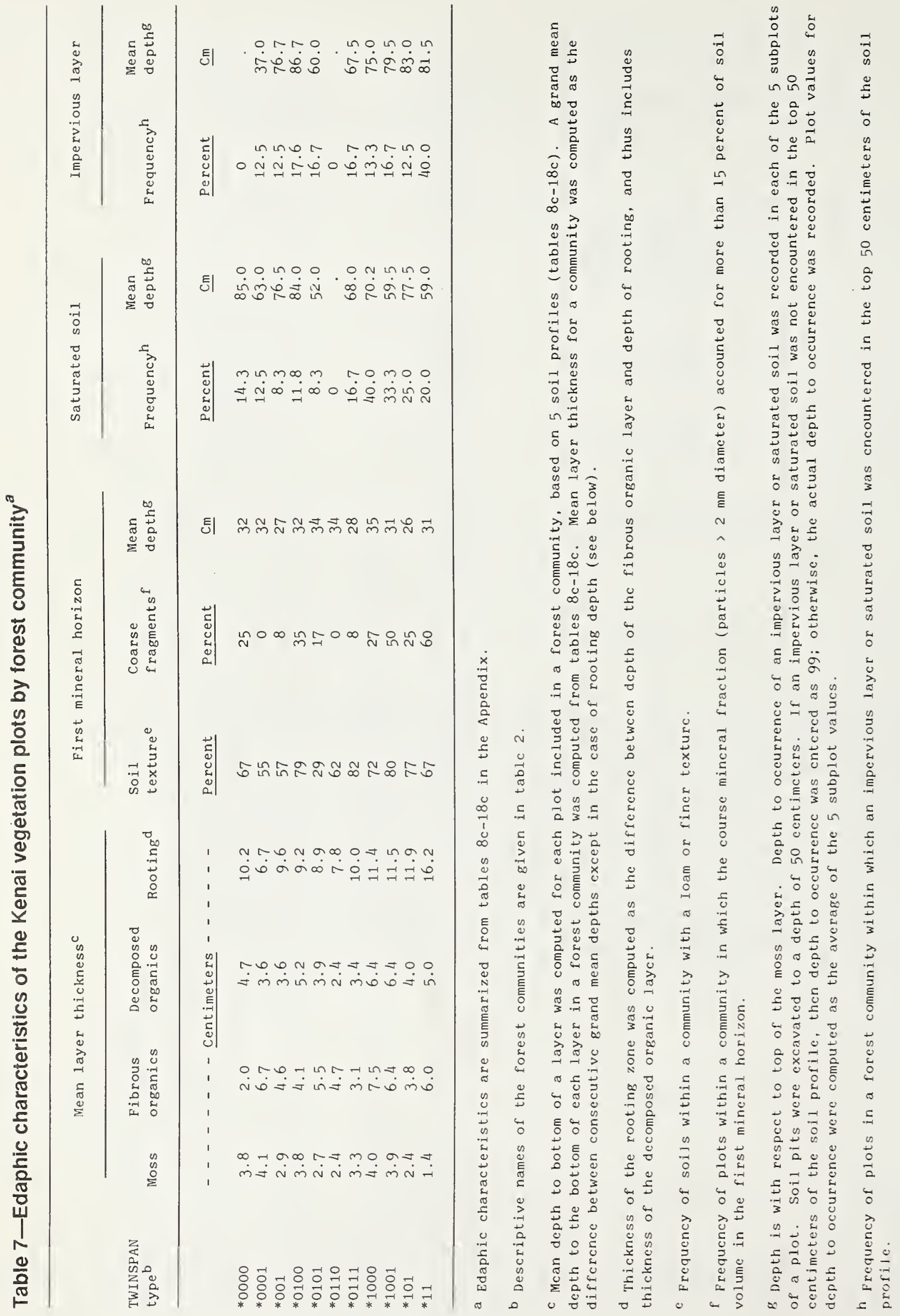


Physiographic

Characteristics of the Communities

Basic Edaphic Characteristics of the Communities
Plots included in TSS *0000 and TSS *0001, are typical of the Kenai Lowlands physiographic region (fig. 1). They occur at low elevations on shallow slopes and rolling terrain and closely resemble black spruce taiga communities of interior Alaska (tables 6 and $8 \mathrm{~b}$ ). A few plots included in these two communities occur on or next to benches within the Kenai Mountains physiographic region. Plots included in TSS *101 are similar in vegetation composition and physiography to Sitka spruce communities of southeast Alaska. On the Kenai Peninsula, this community occurs in both the Kenai Lowlands and Kenai Mountains physiographic regions, but it is restricted to the maritime climatic zone of both regions. TSS *11 consists of riparian Lutz spruceblack cottonwood communities that occur over a fairly broad elevational range, primarily within the Kenai Mountains region.

The seven remaining TSSs occur within the Kenai Mountains region (fig. 1), and all have either Lutz spruce or white spruce, or both, as the principal component of the overstory (tables 2 and 3 ). Four groups of plant communities can be distinguished within these TSSs. The first group includes TSS *001, TSS *0100, TSS *0101, and TSS *0110, and occurs approximately equally on westerly and easterly exposures at lower to middle elevations and in lower- to mid-slope positions (table 6). TSS *0111, TSS *1000, and TSS *1001 generally occur at high elevations and in midslope positions. However, TSS *0111 occurs more or less equally on westerly and easterly exposures, TSS *1000 and TSS *1001 occur predominantly on northerly and southernly exposures, respectively.

A fairly clear distinction between TSSs prefixed by * 0 (the left-side members of fig. 1) and those prefixed by *1 (the right-side members of fig. 1) exists in several basic edaphic features (table 7). Fibrous organic and decomposed organic layers are generally better developed in the * 1 subset than in the * 0 subset. Extent of rooting is also consistantly greater in the ${ }^{*} 1$ subset. All communities included in the * 1 subset have a moderate to high frequency of soils in which the coarse mineral fraction (material $>2$ millimeters in diameter) exceeds 15 percent by volume in the first mineral horizon. In contrast, only two of the seven communities included in the * 0 subset had a moderate incidence of soils in which coarse fragments composed a substantial fraction of the first mineral horizon. The incidence of either saturated soils or impervious layers was low in the * 0 subset. In the * 1 subset, the occurrence of saturated soils or impervious layers, or both, is much higher, which suggests that the *1 subset represents communities generally occurring on wetter sites. Within the *1 subset, TSS *1000 and TSS *1001 represent cool, wet sites with thick fibrous and decomposed organic layers indicative of slower rates of decomposition. These two communities are also the only two described in this study in which mountain hemlock is the primary, or at least a major, component of the overstory. The thickness of organic layers in TSS *101 and TSS *11 are comparable to those in the *0 subset. In contrast to differences in edaphic characteristics noted above, consistant trends across the * 0 and * 1 subsets are not apparent for thickness of the moss layer, soil texture, and depth of the first mineral horizon. 
Stand Structure and Species Composition of the Communities
Closed-open Picea mariana/Cornus canadensis-Vaccinium vitis-idaea/Peltigera spp.-Rhytidiadelphus spp. (TSS *0000)-Open- and closed-canopy stands occur in roughly equal numbers in TSS *0000 (tables 6 and 8b). Black spruce, paper birch, and trembling aspen all occur with high constancy in the overstory, but percent cover is highly variable (table 8 a). White and Lutz spruce are common in the overstory, but the two species occurred together on only one of seven plots. Reproduction of all tree species except black spruce is limited, and most stands included in this community probably represent mid to late seral stages. The shrub layer is dominated by lowbush cranberry. Bunchberry occurs with 100 percent constancy in the shrub layer but with an average cover of only 3.7 percent (tables 5 and 8 a). Relatively few species occur in the forb layer and cover is consistantly low; total cover averages only 3.0 percent (tables 5 and $8 \mathrm{a}$ ). The moss-lichen layer is relatively rich in species, and total cover averages 80.1 percent. Hylocomium spp. are common in this community, but have little diagnostic value, because they ar e common over a range of communities (tables 3 and 4). Peltigera spp. and Rhytidiadelphus spp. were considered useful indicators for this community. The community appears to be similar to the Closed Picea glauca-Picea mariana/Salix spp./Vaccinium vitis-idaea/lichen community described by Yari (1983) for interior Alaska.

Open Picea glauca-Picea mariana/Empetrum nigrum-Vaccinium vitis-idaea/ Peltigera spp.-Pleurozium spp. (TSS *0001)—All stands in TSS *0001 have open canopies (tables 6 and $9 \mathrm{~b}$ ), but the species composition of stands is similar to that for TSS *0000 (tables 3, 4, 8a, and 9a). Differences appeared to be sufficient to justify recognizing a distinct community. In particular, Lutz spruce does not occur in this community at all, and the average cover and constancy of trembling aspen are much lower (table 9a). As with the previous community type, most stands in this community are representative of mid to late seral stages. Total percent cover values in the shrub layer are also similar, and lowbush cranberry dominates the shrub layer, but bunchberry, willow species, and black crowberry also appear with high constancy in this community. Forb layers are also similar, but TSS *0001 is characterized by both greater species richness and greater average total cover. Finally, by way of comparison, Pleurozium schreberi replaces Rhytidiadelphus spp. in this community. Five Picea glauca-Picea mariana communities are described for interior Alaska (Viereck 1979, Yari 1983), but none matches the present description.

Closed Picea glauca-Betula papyriferaNaccinium vitis-idaea/Cornus canadensis/Pleurozium spp. (TSS *001) -With a total of 24 plots, TSS *001 is the most common forest community on the Kenai Peninsula (table 6). Both open and closed canopy structures are common (table 10b). The overstory is composed principally of white spruce and paper birch and, to a lesser extent, trembling aspen (table 10a). White spruce makes up the majority of tree reproduction. In several stands, Lutz spruce is the dominant conifer species. The apparent interchangeability of Lutz and white spruce in this and other communities discussed here is indicative of a high degree of genetic continuity between the two species as a result of genetic introgression (Copes and Beckwith 1977). 
Total overstory cover is generally high in TSS ${ }^{*} 001$, with percent cover ranging up to 205 percent as a result of high cover values in both conifers and broadleaved trees (tables 5 and 10a). Seventy-five percent of the plots examined were classified as having a mixed conifer-broadleaf cover type (tables 6 and 10b). Most stands in this community represent midseral stages when paper birch is replaced by spruce species. Because of the high overstory cover, shrub and forb cover values are somewhat low when compared to other white or Lutz spruce communities; average total cover in these layers is 49.3 and 15.6 percent, respectively (tables 5 and 10a). Lowbush cranberry and bunchberry are the dominant shrub species, but twinflower is also common. Fireweed species and northern commandra are frequent components of the forb layer. Hylocomium spp., and Pleurozium schreberi account for most cover in the moss-lichen layer. Peltigera spp. occur with a constancy of 87 percent, but cover averages only 2.8 percent. Correspondence with previously described Closed Picea glauca-Betula papyrifera communities ${ }^{3,4}$ (Viereck 1975) is relatively poor.

\section{Closed Picea $\times$ lutzii-Betula papyrifera/Menziesia ferruginea-Rubus pedatus/ Gymnocarpium dryopteris/Peltigera spp.-Pleurozium spp. (TSS *0100)-The} majority of stands in TSS ${ }^{*} 0100$ have a closed canopy in which the primary component is Lutz spruce (tables 6 and 11b). In 2 of the 17 plots in this community, the principal overstory component was white spruce (table 11a). Plots included in this community generally represent midseral stages, when birch is replaced by spruce species. Total overstory cover averages 106 percent; paper birch is frequently an important overstory species. Reproduction is generally sparse. In the four plots with substantial reproduction, the reproduction is primarily mountain hemlock, whose presence is indicative of a late seral stage. In species presence, this community shows a high degree of similarity to TSS $* 1000$ (table 3 ), in which mountain hemlock is a primary component of the overstory. It is possible that those stands included here that have significant mountain hemlock reproduction more properly belong to TSS * 1000 . However, the stable community type for many of the stands included in TSS *0100 may be similar both in species composition and cover to that of TSS *1000.

\footnotetext{
${ }^{3}$ Foote, M. Joan. 1976. Classification, description, and dynamics of plant communities following fire in the taiga of interior Alaska. Final report for the Bureau of Land Management. 211 p. On file with: U.S. Department of Agriculture, Forest Service, Institute of Northern Forestry, 308 Tanana Drive, Fairbanks, Alaska 99775-5500.

4 Jorgenson, M. Torre; Slaughter, Charles W.; Viereck, Leslie A. [In preparation]. Relation of vegetation and terraine in the Caribou-Poker Creek Research Watershed, central Alaska. Gen. Tech. Rep. Portland, OR: U.S. Department of Agriculture, Forest Service, Pacific Northwest Research Station. 89 p. Draft version on file with: Institute of Northern Forestry, 308 Tanana Drive, Fairbanks, Alaska 99775-5500.
} 
Rusty menziesia and five-leaf bramble dominate the shrub layer in which total cover averages 60.1 percent (tables 5 and 11a). Twinflower, black crowberry, bunchberry, and lowbush cranberry are common in this layer as well but at lower densities. The principal forb species in this community is oak-fern. Horsetail species and Calamagrostis spp. are also commonly present with constancies of 53 and 65 percent, respectively. As in several other communities, Hylocomium spp. consistantly contribute in large proportion to total cover in the moss-lichen layer. Peltigera spp. and Pleurozium schreberi are considered diagnostic for the community, but Lycopodium spp., Polytrichum spp., Ptilium spp., and Sphagnum spp. also commonly occur. As with the previous community, this one also does not correspond well with previously described Closed Picea glauca-Betula papyrifera communities.

Closed Picea glauca-Betula papyrifera/Menziesia ferruginea-Rubus pedatus/ Gymnocarpium dryopteris/Lycopodium spp.-Pleurozium spp. (TSS *0101)—With respect to stand age, canopy closure, total overstory cover, and physiographic features, TSS *0101 is very similar to TSS *0100 (tables 5 and 6), but 58 percent of the plots in TSS *0101 were classified as mixed conifer-broadleaf, and the primary conifer species is white spruce. In 25 percent of the plots, Lutz spruce occurs instead of white spruce (table 12a). Trembling aspen is rare in this community, and mountain hemlock does not occur at all. The shrub layer in this community is similar to that of TSS *0100 in that rusty menziesia, five-leaf bramble, and bunchberry are the primary species. Twinflower and highbush cranberry, rather than lowbush cranberry, are common. The principal forb species is oak-fern. Other common members of the forb layer are spinulose shield fern, wintergreen species, starflower, and Calamagrostis spp. Lycopodium spp. and Pleurozium spp. are characteristic species of the moss-lichen layer. Hylocomium spp. occur with 100 percent constancy, but percent cover is much lower than in TSS *0100 (tables 3 and 4). This community does not seem to be previously described.

Open Picea glauca-Picea $\times$ lutzii/Linnea borealis-Rubus pedatus/Sanguisorba spp.-Calamagrostis spp./Lycopodium spp.-Ptilium spp. (TSS *0110)-Most stands in TSS *0110 have an open canopy structure (tables 6 and 13b), but saplings contribute substantially to total cover, which averages 109 percent (tables 5 and 13a). Coniferous and mixed conifer-broadleaf cover types are about equally represented. Paper birch occurred on all plots with generally low cover. In two plots, paper birch was the primary overstory cover species. Lutz and white spruce both contribute about 35 percent of overstory cover and occur with constancies of 67 and 44 percent, respectively. Both species were present in 25 percent of the plots. Despite the generally open canopy structure, reproduction is low in this community, possibly as a result of the consistant occurrence of Calamagrostis spp. TSS *0110 generally represents a rather narrow range of mid seral stages. 
Total shrub cover averages 46.6 percent (tables 5 and 13a). Five-leaf bramble and twinflower both occur with 100 percent constancy and together comprise the majority of shrub species cover, but bunchberry is also relatively common. Fireweed species, oak-fern, burnet species, and Calamagrostis spp. all occur in the forb layer with 100 percent cover (table 13a). Of the latter, burnet species and Calamagrostis spp. were considered as diagnostic for this community. Horsetail species are also common as are, to a lesser extent, spinulose shield fern, northern geranium, and wintergreen species. Several species are also very common in the moss-lichen layer; they include Hylocomium spp., Lycopodium spp., Mnium spp., Pleurozium schreberi, and Ptilium spp. Dicranum spp., and Rhytidiadelphus spp. are also fairly common. Considering only species that occur witll high constancy, the forb and moss-lichen layers of this community are the most floristically diverse among the communities described here. The community TSS *0110 does not correspond well with any of the seven Open Picea glauca communities previously described for the interior (Viereck 1979, Yari 1983).

\section{Open-Closed Picea $\times$ Iutzii/Rubus pedatus-Salix spp./Sanguisorba spp.-} Calamagrostis spp./Mnium spp. (TSS *0111)-Open-and closed-canopy stands are equally represented in TSS *0111 (tables 6 and 14b). Saplings frequently represent a major contribution to total cover. Lutz spruce is the primary component of the overstory, but stands with white spruce overstories also occur in the community (table 14a). The predominant cover type is coniferous. In contrast to TSS *0101 and TSS *0110, paper birch is only a minor component of the overstory in this community (table 3) and often is not present at all (table 4). Stand ages are similar for all three of these communities (table 6), so that the lower occurrence of paper birch is probably not indicative of a later seral stage for TSS *0111. Instead, the general absence of birch is most likely due to stands in this community occurring at much higher elevations (table 6).

Total shrub cover in TSS *0111 averages 49.7 percent (tables 5 and 14a), and five-leaf bramble is again the most important species contributing to cover in both percent cover and constancy (table 14a). Willow species are also diagnostic for the community. Although average cover for willows is only 6 percent, willow species occur with a much higher constancy than they do in TSS *0110 (tables 4 and 14a). As in TSS *0110, horsetails, oak-fern, and Calamagrostis spp. appear with high constancy in this community (tables $4,13 \mathrm{a}$, and $14 \mathrm{a}$ ). The relative abundances differ considerably, with percent cover of horsetails being more than three times higher in this community; but percent cover of oak-fern and grasses is only about half that in TSS *0110. Fireweed species, northern geranium, and wintergreen occur with about equal constancy in both communities as well. Percent cover values for the latter two species are comparable, but percent cover of fireweed averages three times higher in TSS *0110. Mnium spp. are characteristic of the moss-lichen layer. Besides Hylocomium spp., species common to the community that contribute substantially to total cover are Lycopodium spp., Pleurozium schreberi, and Polytrichum spp. The Open Picea glauca/Salix bebbiana/Rosa acicularis/Equisetum spp.-Epilobium spp./lichen community of Yari (1983) is somewhat similar to the present community although the principle overstory species here is Lutz spruce and Rosa acicularis is generally absent. 
Closed Picea $\times$ lutzii-Tsuga mertensiana/Cornus canadensis-Menziesia ferruginea/Sphagnum spp. (TSS ${ }^{*} 1000$ )-TSS ${ }^{*} 1000$ and the two discussed next are the most consistant in canopy closure and forest type because they are composed primarily of closed coniferous stands (table 6). Average total overstory cover in this community is 120 percent (table 15a). Mountain hemlock occurs with 100-percent constancy and is the principal cover in the overstory of older siands; in younger stands Lutz spruce forms the majority of the overstory cover (tables 15a and 15b). Older stands in this community are probably at or near a stable canopy structure. Two stands in which the spruce component is Sitka spruce are also included in this community. Paper birch is absent from most stands, but in plot 143, where the spruce component averages 49 years of age, paper birch accounts for 100 percent cover. Most of the reproduction in this community is also mountain hemlock and averages 10.5 percent.

Total shrub cover is relatively low at an average of only 36.7 percent (tables 5 and 15a). Rusty menziesia is the most important species in cover and constancy (tables $15 \mathrm{a}$ and 15b). Five-leaf bramble and bunchberry occur with constancies of 80 and 92 percent, respectively, but average cover for these species is only about 3 percent. Total forb cover is extremely low compared to most other communities described in this study, and no species has high constancy. The moss-lichen layer is composed primarily of Hylocomium spp., Pleurozium schreberi, and Sphagnum spp., but Rhytidiadelphus spp. also commonly occur at moderate cover values.

\section{Closed Picea $\times$ lutzli-Tsuga mertensiana/Menziesia ferruginea-Oplopanax} horridum/Dryopteris dilatata/Mnium spp.-Rhytidiadelphus spp. (TSS *1001) General overstory structure in TSS ${ }^{*} 1001$ is very similar to that for TSS *1000) because it is almost exclusively a closed coniferous type (tables 5 and 16a). Species composition is very similar, with the contribution of mountain hemlock to total overstory cover tending to be greater in older stands (tables 16a and 16b). Older stands in this community probably also represent stable communities. Tree reproduction is primarily mountain hemlock.

The shrub layer in TSS *1001 is similar to that for TSS *1000; however, devil's club also appears in this community with an average cover of 6 percent and a constancy of 83 percent (tables 3, 4, 15a, and 16a). Spinulose shield fern and oak-fern are the principal species in the forb layer. The principal species in the moss-lichen layer are Hylocomium spp., Mnium spp., and Rhytidiadelphus spp. Dicranum spp. are also common in the moss-lichen layer. Only one mountain hemlock community is described for Alaska (Martin 1989). The current community, which includes a significant spruce component in the overstory, is generally similar to that described by Martin (1989) but probably represents a somewhat earlier seral stage. 
Closed Picea sitchensis/Oplopanax horridum-Rubus pedatus/Dryopteris dila tata-Gymnocarpium dryopteris/Mnium spp.-Rhytidiadelphus spp. (TSS *101)Stands in TSS *101 usually have closed canopies and are, perhaps, exclusively coniferous (tables 6 and 17b). In roughly half the stands, the overstory is pure Sitka spruce (table 17a). Stands dominated by mountain hemlock or Lutz spruce are also included in this community, but, as is the case with introregression between white and Lutz spruce, Lutz spruce trees in this community tend to be more like Sitka spruce in morphology. Broad-leaved species are absent or at least rare in TSS ${ }^{101}$ and reproduction is generally low. Stands included in this community represent mid to late seral stages.

Devil's club and five-leaf bramble comprise the majority of shrub cover, which averages 56.6 percent (tables 5 and 17a). Spinulose shield fern and oak-fern each occur with about 15 percent cover and account for about 60 percent of total cover within the forb layer (table 17a). Tiarella spp. are the only other species that occur with a high degree of constancy in the forb layer. In the moss-lichen layer, Hylocomium spp., Mnium spp., and Rhytidiadelphus spp. occur with high constancy and together account for almost 75 percent of the cover. Martin (1989) has described three Picea sitchensis/Oplopanax horridum communities for southeast and south-central Alaska. The Closed Picea sitchensis/Vaccinium spp./Oplopanax horridum community corresponds quite well with the present description.

Open Picea $\times$ lutzii-Populus trichocarpa/Alnus spp.-Oplopanax horridum/Dryopteris dilatata (TSS *11)-TSS *11 is a rather small, heterogeneous collection of flood-plain and riparian stands that are quite variable in structure and composition of the overstory (tables $18 \mathrm{a}$ and $18 \mathrm{~b}$ ). It is, however, the only community where black cottonwood assumes any consistant importance as a component of the overstory (tables 3 and 4). Species presence and cover are considerably more uniform in the lower vegetation layers. For example, alder species, devil's club, and red elderberry occur with 100-percent constancy in the shrub layer of this community (table 18a). These three species together constitute almost 90 percent of total shrub cover. It is also the only community in which alder species and red elderberry achieve a high degree of constancy (table 4). Spinulose shield fern averages 20 percent cover in the forb layer and is the only species in this layer with high constancy. No species in the moss-lichen layer can be considered typical of the community. In fact, no cover was recorded for this layer in plots 23 and 31 . No detailed descriptions exist for white spruce-black cottonwood or Lutz spruce-black cottonwood communities, but a general description of Open Picea glauca-Populus trichocarpa communities in the Susitna River Basin (USDA Soil Conservation Service 1986) is similar to that presented here. 


\section{Conclusions}

\section{Acknowledgments}

\section{Literature Cited}

Several forest communities described here have not been described previously, although all are compatible with the level IV classes of Viereck and Dyrness (1980). Viereck and Dyrness recently have completed a revision of the original classification system for Alaska that recognizes additional communities and includes level $\mathrm{V}$ community descriptions. ${ }^{5}$ Communities described here that include white or Lutz spruce as the principal overstory species seem to be sufficiently distinct from communities previously described in Alaska to warrant inclusion in a future revision to the vegetation classification system.

Community classification may be interesting as an end in itself, but more often interest in classification extends to developing hypotheses about the relation of community composition to environmental gradients (Grieg-Smith 1983). In addition, community classification can have important and direct implications for forest management, because community composition and the environmental factors influencing it can affect both optimum management and use of timberland. For example, Reynolds and Hard (in press) have estimated risk and hazard of spruce beetle (Dendroctonus rufipennis Kirby) attack for forest communities on the Kenai Peninsula. Numerous other applications to forest management on the peninsula could similarly be developed on the basis of community type.

This report was the result of efforts by many individuals, most notably the scientists of the Forestry Sciences Laboratory in Anchorage (Forest Inventory and Analysis Research Work Unit), who were responsible for designing and implementing the survey. In particular, I thank Gary Carroll and Bert Mead for their assistance with initial data preparation, and Jim Labau, Fred Larsen, and Ken Winterberger for technical review. I also thank Ted Dyrness, Les Viereck, and Joan Foote of the Institute of Northern Forestry, Fairbanks, and Jon Martin, Alaska Region, for their many helpful suggestions on interpreting the analysis.

Copes, Donald L.; Beckwith, Roy C. 1977. Isoenzyme identification of Picea glauca, $P$. sitchensis, and P. lutzii populations. Botanical Gazette. 138: 512-521.

Crum, H.A.; Steere, W.C.; Anderson, L.E. 1973. A new list of mosses of North America north of Mexico. Bryologist. 76: 85-130.

Gauch, Hugh G. Jr. 1982. Multivariate analysis in community ecology. New York: Cambridge University Press. 298 p.

Grieg-Smith, P. 1983. Quantitative plant ecology. Berkeley, CA: University of California Press. 359 p.

Hale, M.E., Jr.; Culberson, W.L. 1970. A fourth checklist of the lichens of the continental United States and Canada. Bryologist. 73: 499-543.

\footnotetext{
5 Personal communication, February 5, 1989, L.A. Viereck, research ecologist, and C.T. Dyrness, research soil scientist, U.S. Department of Agriculture, Forest Service, Instifute of Northern Forestry, 308 Tanana Drive, Fairbanks, Alaska 99775-5500.
} 
Hill, M.O. 1973. Reciprocal averaging: an eigenvector method of ordination. Journal of Ecology. 61: 237-249.

Hill, M.O. 1979. TWINSPAN: A FORTRAN program for arranging multivariate data in an ordered two-way table by classification of the individuals and attributes. Ithaca, NY: Cornell University. $90 \mathrm{p}$.

Hill, M.O.; Bunce, R.G.H.; Shaw, M.W. 1975. Indicator species analysis, a divisive polythetic method of classification, and its application to a survey of native pine woods in Scotland. Journal of Ecology. 63: 597-613.

Hulten, E. 1968. Flora of Alaska and neighboring territories. Stanford, CA: Stanford University Press. 1,008 p.

Martin, G.C.; Johnson, B.L.; Grant, U.S. 1915. Geology and mineral resources of Kenai Peninsula, Alaska. Washington, DC: U.S. Department of the Interior, U.S. Geological Survey. 243 p.

Martin, Jon R. 1989. Vegetation and environment in old growth forests of northern southeast Alaska: a plant association classification. Flagstaff: Arizona State University. 221 p. M.S. thesis.

Pewe, Tres L. 1975. Quaternary geology of Alaska. Prof. Paper 835. [Location of publisher unknown]: U.S. Department of the Interior, U.S. Geological Survey. 12 p.

Pojar, J.; Klinka, K.; Meidinger, D. V. 1987. Biogeoclimatic ecosystem classification in British Columbia. Forest Ecology and Management. 22: 119-154.

Reynoids, K.M.; Hard, J.S. [in press]. Risk and hazard of spruce beetle attack in unmanaged stands on the Kenai Peninsula, Alaska, under epidemic conditions. Forest Ecology and Management.

Rowe, J.S. 1972. Forest regions of Canada. Publ. 1300. [Location of publisher unknown]: Canada Department of the Environment. Canadian Forestry Service. [not paged].

Selkregg, L.L., comp. 1974. Alaska regional profiles: south-central region. [Location of the publisher unknown]: The University of Alaska, Arctic Environmental Information and Data Center. 255 p. In cooperation with: The Joint Federal-State Land Use Planning Commission for Alaska.

U.S. Department of Agriculture, Soil Conservation Service. 1986. Timber and vegetation resources of the Susitna River Basin, Alaska. Fort Richardson, AK: U.S. Army Publication Center. 224 p. In cooperation with: State of Alaska, Department of Natural Resources. 
Viereck, Leslie A. 1975. Forest ecology of the Alaska taiga. In: Proceedings of the Circumpolar Conference on Northern Ecology; 1975 September 15-18; Ottawa, ON: National Research Council of Canada; 1975: 1-1 to 1-22.

Viereck, Leslie A. 1979. Characteristics of treeline plant communities in Alaska. Holartic Ecology. 2: 228-238.

Viereck, Leslie A.; Dyrness, C.T. 1980. A preliminary classification system for vegetation of Alaska. Gen. Tech. Rep. PNW-106. Portland, OR: U.S. Department of Agriculture, Forest Service, Pacific Northwest Research Station. 38 p.

Viereck, Leslie A.; Little, Elbert L., Jr. 1972. Alaska trees and shrubs. Agric. Handb. 410. Washington, DC: U.S. Department of Agriculture. 265 p.

Yari, John. 1983. Forest community classification of the Porcupine River drainage, interior Alaska, and its application to forest management. Gen. Tech. Rep. PNW154. Portland, OR: U.S. Department of Agriculture, Forest Service, Pacific Northwest Forest and Range Experiment Station. $68 \mathrm{p}$. 


\section{Appendix}

Table 8a-Species composition of Kenai vegetation plots included in the Closed Picea mariana/Cornus canadensis-Vaccinium vitis-idaea/Peltigera spp.-Rhytidiadelphus spp. community, TWINSPAN subset *0000

\begin{tabular}{|c|c|c|c|c|c|c|c|c|c|}
\hline \multirow[b]{2}{*}{ Species } & \multicolumn{7}{|c|}{ Plots } & \multirow{2}{*}{$\begin{array}{c}\text { Average } \\
\text { cover }\end{array}$} & \multirow[b]{2}{*}{ Const ancy } \\
\hline & 30 & 38 & 40 & 42 & 56 & 129 & 135 & & \\
\hline & -- & - - & $-\quad \underline{P}$ & rcent & $\operatorname{cov}$ & $\mathrm{r}^{\mathrm{a}}-$ & - - - & $-\quad P e$ & rcent $^{b}-$ \\
\hline \multicolumn{10}{|l|}{ Overstory: } \\
\hline Betula papyrifera & $\mathrm{Tr}$ & 13 & $\operatorname{Tr}$ & $\operatorname{Tr}$ & 67 & 32 & 31 & 20.6 & 100 \\
\hline Picea glauca & 32 & - & - & 23 & 17 & 32 & - & 14.9 & 57 \\
\hline Picea mariana & 35 & 99 & 57 & 57 & 14 & 18 & 31 & 44.4 & 100 \\
\hline Picea X lutzii & - & - & 25 & - & 54 & - & 37 & 16.6 & 43 \\
\hline Popu1us tremu1oides & $\mathrm{Tr}$ & - & 48 & 8 & 31 & 30 & 15 & 18.9 & 86 \\
\hline Total & 68 & 112 & 130 & 88 & 183 & 112 & 114 & $115 \cdot 3$ & \\
\hline \multicolumn{10}{|l|}{ Reproduction: } \\
\hline Betula papyrifera & - & - & - & - & - & 3 & - & 0.4 & 14 \\
\hline Picea glauca & 4 & - & $\cdot-$ & 3 & - & - & - & 1.0 & 29 \\
\hline Picea mariana & 7 & 53 & 6 & 6 & 14 & 15 & 3 & 14.9 & 100 \\
\hline Populus tremuloides & - & - & 1 & - & - & 2 & - & 0.4 & 29 \\
\hline Total & 11 & 53 & 7 & 9 & 14 & 20 & 3 & 16.7 & \\
\hline \multicolumn{10}{|l|}{ Shrubs: } \\
\hline Betula nana & - & - & - & 12 & - & - & 4 & 2.3 & 29 \\
\hline Cornus canadensis & 5 & 1 & 8 & 5 & 2 & 3 & 2 & 3.7 & 100 \\
\hline Cornus suecica & - & - & - & - & 1 & - & - & 0.1 & 14 \\
\hline Empetrum nigrum & 11 & - & - & 18 & - & 26 & 23 & 11.1 & 57 \\
\hline Ledum groenlandicum & 6 & - & - & - & 1 & - & - & 1.0 & 29 \\
\hline Linnaea borealis & 7 & - & - & 1 & - & 16 & 2 & $3 \cdot 7$ & 57 \\
\hline Rosa acicularis & 3 & - & - & - & 5 & 1 & - & 1.3 & 43 \\
\hline Rubus spp. & - & - & - & - & - & - & 4 & 0.6 & 14 \\
\hline sa1ix spp. & - & - & 4 & 1 & - & 2 & - & 1.0 & 43 \\
\hline Spiraea spp. & - & - & - & - & 1 & - & 17 & 2.6 & 29 \\
\hline Vaccinium vitis-idaea & 19 & 22 & 39 & 28 & 43 & 27 & 6 & 26.3 & 100 \\
\hline Other Vaccinium spp. & 25 & 0 & 0 & 0 & 0 & 2 & 0 & 3.9 & 29 \\
\hline Tota1 & 76 & 23 & 51 & 65 & 53 & 77 & 58 & 57.6 & \\
\hline \multicolumn{10}{|l|}{ Forbs: } \\
\hline Geocaulon 1ividum. & 5 & - & - & 2 & - & 6 & - & 1.9 & 43 \\
\hline Epilobium spp. & 2 & - & 3 & - & - & - & - & 0.7 & 29 \\
\hline Equisetum spp. & - & - & 2 & - & - & - & - & 0.1 & 14 \\
\hline Lupinus spp. & - & - & 1 & - & - & - & - & 0.1 & 14 \\
\hline Tota 1 & 7 & - & 6 & 6 & - & 6 & - & 3.0 & \\
\hline \multicolumn{10}{|l|}{ Grasses: } \\
\hline Calamagrostis spp. & 3 & - & - & - & - & - & - & 0.4 & 14 \\
\hline Carex spp. & - & - & 1 & 1 & - & - & - & 0.3 & 29 \\
\hline \multicolumn{10}{|l|}{ Mosses and 1 ichens: } \\
\hline A1ectoria spp. & 1 & - & - & 1 & 2 & - & 3 & 1.0 & 57 \\
\hline Au1acomnium spp. & - & 12 & - & - & - & - & 3 & 1.1 & 29 \\
\hline Cladina spp. & - & 1 & - & 4 & - & - & 1 & 0.9 & 43 \\
\hline Cladonia spp. & 1 & 5 & 6 & 1 & - & 1 & 1 & 1.1 & 86 \\
\hline Dicranum spp. & - & 3 & - & - & 1 & 1 & 2 & 1.0 & 57 \\
\hline Hylocomium spp. & 5 & 8 & - & 5 & 39 & 8 & 26 & 13.0 & 86 \\
\hline Hypogmnia spp. & - & - & 1 & 1 & - & - & 1 & 0.4 & 43 \\
\hline Other 1 ichen species & 4 & - & - & - & - & - & - & 0.6 & 14 \\
\hline Lobaria spp. & - & - & 1 & - & - & - & - & 0.1 & 14 \\
\hline Other moss species & 7 & 3 & 1 & 2 & 1 & 2 & - & $2 \cdot 3$ & 86 \\
\hline Nephroma spp. & - & - & - & - & - & - & 2 & 0.3 & 14 \\
\hline
\end{tabular}

See footnotes at end of table. 


\begin{tabular}{|c|c|c|c|c|c|c|c|c|c|}
\hline \multirow[b]{2}{*}{ Species } & \multicolumn{7}{|c|}{ Plots } & \multirow{2}{*}{$\begin{array}{l}\text { Average } \\
\text { cover }\end{array}$} & \multirow[b]{2}{*}{ Constancy } \\
\hline & 30 & 38 & 40 & 42 & 56 & 129 & 135 & & \\
\hline & - - & - - & -1 & rcen & $\operatorname{cov}$ & $e r^{a}-$ & $-\ldots$ & $-\quad P e$ & rcent $^{b}$ - - \\
\hline \multicolumn{10}{|l|}{ Mosses and lichens: } \\
\hline Peltigera spp. & 2 & 5 & 6 & 5 & 4 & 2 & 4 & 4.0 & 100 \\
\hline Pleurozium schreberi & - & 30 & - & 60 & 29 & - & 20 & 19.9 & 57 \\
\hline Polytrichum spp. & 4 & - & 8 & 1 & 4 & 4 & 3 & 3.4 & 86 \\
\hline Ptilium spp. & - & - & 3 & - & 5 & 5 & 3 & 2.3 & 57 \\
\hline Rhytidiadelphus spp. & 58 & 3 & 41 & 8 & - & 52 & 1 & $23 \cdot 3$ & 86 \\
\hline Sphagnum spp. & - & - & - & - & 4 & - & 20 & 3.4 & 29 \\
\hline Total & 82 & 70 & 67 & 88 & 89 & 75 & 90 & $\overline{80.1}$ & \\
\hline
\end{tabular}

a $\mathrm{Tr}$ indicates that the cover of a species within a plot was < 1 percent cover. A dash indicates that the species was absent.

b Tr indicates that the average cover of a species was $<0.1$ of 1 percent.

\section{Table $8 \mathrm{~b}-$ Site characteristics of Kenai vegetation plots belonging to the Closed Picea mariana Naccinium vitis-idaea/Cornus canadensis/Peltigera spp.-Rhytidiadelphus spp. community, TWINSPAN subset *0000}

\begin{tabular}{|c|c|c|c|c|c|c|c|}
\hline Plot & Elevation & $\begin{array}{l}\text { Principal } \\
\text { cover }\end{array}$ & Closure ${ }^{b}$ & $\begin{array}{l}\text { Stand } \\
\text { age }\end{array}$ & $\begin{array}{l}\text { Slope } \\
\text { position }\end{array}$ & Slope & Aspect \\
\hline & Meters & & & Years & & Percent & \\
\hline 30 & 182.9 & Conifer & Open & 133 & Mid & 23.0 & SW \\
\hline 38 & 121.9 & Conifer & Closed & 25 & Rolling & 2.6 & None \\
\hline 40 & 61.0 & Mixed & Open & $\mathrm{NA}$ & Rolling & 8.0 & None \\
\hline 42 & 30.5 & Conifer & Closed & 60 & Rolling & 1.0 & None \\
\hline 56 & 91.4 & Hardwood & Closed & 112 & Low & 4.8 & $N W$ \\
\hline 129 & 152.4 & Hardwood & Closed & 80 & Mid & 32.2 & SE \\
\hline 135 & 121.9 & Conifer & Open & 108 & Mid & 4.8 & $\mathrm{NW}$ \\
\hline
\end{tabular}

a A stand was classified as conifer if coniferous overstory trees contributed at least 75 percent of tree cover, and similarly for hardwoods. A stand was classified as mixed if neither overstory conifers nor hardwoods contributed at least 75 percent of tree cover.

b A stand was classified as closed, open, or woodland if overstory tree cover was at least 60,25 , or 10 percent, respectively. Stands with $<10$ percent cover were considered to be nonforest 1 and.

c Stand age was calculated as the average of as many as 6 coniferous site trees. Site trees were individuals that had maintained a dominant or codominant canopy position for most of their lives. When possible, site trees were selected from those trees included in the variable-radius plots. If an insufficient number of site trees was obtained from the variable-radius plots, then additional neighboring trees meeting the site tree criterion were selected if possible.

d Possible values for slope (topographic) position were flat, low(er slope), mid(slope). upper (slope), and rolling (terrain).

e Possible values for aspect are the cardinal compass directions (N, S, E, and $W$ ) or combinations (for example, NW, SE) 
Table $8 \mathrm{c}$-Soil characteristics of Kenai vegetation plots belonging to the Closed Picea mariana/Naccinium vitis-idaea/Cornus canadensis/Peltigera spp.-Rhytidiadelphus spp. community, TWINSPAN subset *0000

\begin{tabular}{|c|c|c|c|c|c|c|c|c|c|}
\hline \multirow[b]{2}{*}{ Plot } & \multicolumn{6}{|c|}{ Depth of: $a$} & \multicolumn{3}{|c|}{ Top mineral horizon } \\
\hline & $\begin{array}{l}\text { Impervious } \\
\text { layer }\end{array}$ & $\begin{array}{l}\text { Saturated } \\
\text { soilb }\end{array}$ & $\begin{array}{l}\text { Root } \\
\text { depth }\end{array}$ & $\begin{array}{l}\text { Moss } \\
\text { layer }\end{array}$ & $\begin{array}{l}\text { Fibrous } \\
\text { organic }\end{array}$ & $\begin{array}{l}\text { Decomposed } \\
\text { organic }\end{array}$ & Texture ${ }^{c}$ & $\begin{array}{l}\text { Coarse } \\
\text { fragments }\end{array}$ & Deptha \\
\hline & ---- & ---- & - Cent & imeters & ---- & ----- & & & $\mathrm{Cm}$ \\
\hline 30 & 85 & - & 12 & 4 & 7 & 11 & SiL-SL & $V L-L$ & 24 \\
\hline 38 & - & - & 14 & 2 & 5 & 8 & SL & VL & 28 \\
\hline 40 & - & - & 13 & 2 & 5 & 9 & SiL-L & VL & 31 \\
\hline 42 & - & - & 14 & 5 & 8 & 11 & SL & $V L-L$ & 39 \\
\hline 56 & - & - & 27 & 6 & 10 & 13 & $\mathrm{SiL}$ & VL & 29 \\
\hline 129 & - & - & 21 & 4 & 8 & 12 & SiL-SL & VL & 32 \\
\hline 135 & - & - & 11 & 4 & 8 & 10 & SiL & VL & 42 \\
\hline
\end{tabular}

a All depths were relative to the top of the moss layer on the soil surface.

b A dash indicates that a specific type of soil feature was not observed within the first 50 centimeters below the soil surface.

c Soil texture was determined for each of the 5 subplots. Texture classes were cL = clay loam. SiL = silt loam, L = loam, $S L=$ sandy loam, and LS = loamy sand (or sand). For each plot, if the same texture class was recorded on at least 4 of the subplots, then that texture class is reported for the plot, otherwise a range of texture classes is indicated.

d The mineral fraction > $2 \mathrm{~mm}$ diameter was classed as coarse fragments. Coarse fragment content was recorded as very low (VL < 15 percent), low (15 percent < L < 30 percent), moderate ( 30 percent < $4<60$ percent), or high (H>60 percent). 


\begin{tabular}{|c|c|c|c|c|c|c|c|c|c|c|}
\hline \multirow[b]{2}{*}{ Species } & \multicolumn{8}{|c|}{ P1ots } & \multirow{2}{*}{$\begin{array}{c}\text { Average } \\
\text { cover }\end{array}$} & \multirow[b]{2}{*}{ Constancy } \\
\hline & 22 & 24 & 25 & 27 & 29 & 79 & 133 & 142 & & \\
\hline & -- & -- & $-\underline{-P \epsilon}$ & rcent & $\operatorname{cov}$ & $e^{a}-$ & -- & -- & ---1 & ercent $^{\mathrm{b}}-$ \\
\hline \multicolumn{11}{|l|}{ Overstory: } \\
\hline Betula papyrifera & 9 & 31 & - & 10 & - & 28 & 53 & 11 & $17 \cdot 7$ & 75 \\
\hline Picea glauca & 68 & 64 & - & - & 61 & 64 & 36 & 7 & $37 \cdot 5$ & 75 \\
\hline Picea mariana & 49 & 4 & 100 & 74 & 48 & 39 & - & 40 & 44.2 & 87 \\
\hline Populus tremuloides & - & 10 & - & - & $\operatorname{Tr}$ & - & - & - & $1 \cdot 3$ & 25 \\
\hline Total & 116 & 109 & 100 & 84 & 109 & 131 & 89 & 58 & 99.5 & \\
\hline \multicolumn{11}{|l|}{ Reproduction: } \\
\hline Betula papyrifera & - & 1 & - & 3 & - & - & - & - & 0.5 & 25 \\
\hline Picea glauca & 2 & - & - & - & 3 & 1 & - & - & 0.7 & 37 \\
\hline Picea mariana & - & 3 & 14 & 8 & 17 & - & - & 8 & 6.2 & 62 \\
\hline Total & 2 & 4 & 14 & 11 & 20 & 1 & 0 & 8 & $7 \cdot 5$ & \\
\hline \multicolumn{11}{|l|}{ Shrubs: } \\
\hline Alnus spp. & - & - & - & - & - & - & - & 5 & 0.6 & 12 \\
\hline Arctostaphylos uva-ursi & - & - & - & - & - & - & - & 2 & 0.2 & 12 \\
\hline Betula nana & 8 & - & - & - & - & - & - & 1 & 1.1 & 25 \\
\hline Cornus canadensis & 10 & 8 & 6 & 1 & 1 & 4 & 8 & 7 & 5.6 & 100 \\
\hline Cornus suecica & 3 & - & - & - & 1 & - & - & 7 & 1.4 & 37 \\
\hline Empetrum nigrum & 14 & 12 & - & 10 & 7 & 21 & 10 & 15 & 11.1 & 87 \\
\hline Ledum groenlandicum & - & - & - & 1 & - & - & - & 4 & 0.6 & 25 \\
\hline Ledum palustre decumbens & 11 & - & 1 & - & 9 & - & - & 6 & 3.4 & 50 \\
\hline Linnaea borealis & 4 & 1 & - & 1 & 1 & 9 & 7 & - & 2.9 & 75 \\
\hline Menziesia ferruginea & - & 1 & - & 29 & - & - & 55 & - & 10.6 & 37 \\
\hline Ribes spp. & 1 & - & - & - & - & - & - & 5 & 0.7 & 25 \\
\hline Rosa acicularis & - & - & - & - & - & - & 1 & 8 & 1.1 & 25 \\
\hline Rubus spp. & 15 & 3 & - & - & - & - & 2 & - & 2.5 & 37 \\
\hline Salix spp. & 3 & 7 & 1 & 1 & 12 & 1 & - & 11 & 4.5 & 87 \\
\hline Spiraea spp. & 7 & 8 & - & - & 1 & - & - & - & 2.0 & 37 \\
\hline Vaccinium vitis-idaea & 6 & 16 & 18 & 7 & 22 & 42 & 27 & 2 & $17 \cdot 5$ & 100 \\
\hline Other Vaccinium spp. & 16 & 0 & 0 & 0 & 18 & 0 & 0 & 9 & 5.4 & 37 \\
\hline Total & 98 & 56 & 26 & 50 & 72 & 77 & 110 & 82 & 71.4 & \\
\hline \multicolumn{11}{|l|}{ Forbs: } \\
\hline Epilobium spp. & 2 & 1 & 1 & - & 2 & - & - & - & 0.7 & 50 \\
\hline Equisetum spp. & - & 1 & - & - & - & - & - & 19 & 2.5 & 25 \\
\hline Geocaulon lividum & - & 2 & - & 2 & 6 & 6 & 6 & - & 2.7 & 62 \\
\hline Gymnocarpium dryopteris & - & 8 & - & - & - & - & 1 & - & 1.1 & 25 \\
\hline Lupinus spp. & - & - & - & - & - & 3 & - & - & 0.4 & 12 \\
\hline Potentilla spp. & - & - & - & - & - & - & - & 2 & 0.2 & 12 \\
\hline Sanguisorba spp. & 4 & - & - & - & - & - & - & 2 & 0.7 & 25 \\
\hline Total & 6 & 12 & 1 & 2 & 8 & 9 & 7 & 23 & 5.0 & \\
\hline \multicolumn{11}{|l|}{ Grasses: } \\
\hline Calamagrostis spp. & 6 & 1 & - & - & - & - & - & 4 & 1.4 & 37 \\
\hline \multicolumn{11}{|l|}{ Mosses and 1ichens: } \\
\hline Alectoria spp. & - & 1 & - & - & - & - & - & - & 0.1 & 12 \\
\hline Cladina spp. & - & - & 23 & 2 & 5 & - & - & 1 & 3.9 & 50 \\
\hline Cladonia spp. & - & - & - & - & - & - & 1 & - & 0.1 & 12 \\
\hline Dicranum spp. & - & - & - & 1 & 1 & - & - & - & 0.2 & 25 \\
\hline Hylocomium spp. & 7 & 19 & 2 & 27 & 28 & 34 & 17 & 10 & 18.0 & 100 \\
\hline Hypogmnia spp. & 1 & - & 1 & 1 & - & - & - & - & 0.4 & 37 \\
\hline Lycopodium spp. & 5 & 7 & - & - & 1 & 13 & 5 & - & 3.9 & 62 \\
\hline Mnium spp. & - & - & - & - & - & - & - & 1 & 0.1 & 12 \\
\hline
\end{tabular}

See footnotes at end of table. 


\begin{tabular}{|c|c|c|c|c|c|c|c|c|c|c|}
\hline \multirow[b]{2}{*}{ Species } & \multicolumn{8}{|c|}{ Plots } & \multirow{2}{*}{$\begin{array}{l}\text { Average } \\
\text { cover }\end{array}$} & \multirow[b]{2}{*}{ Constancy } \\
\hline & 22 & 24 & 25 & 27 & 29 & 79 & 133 & 142 & & \\
\hline & -- & - - & $-\underline{P E}$ & cent & cove & $\mathrm{r}^{\mathrm{a}}-$ & - - & - & --1 & ercent $^{b}$ - - \\
\hline \multicolumn{11}{|l|}{ Mosses and lichens: } \\
\hline Other moss species & 2 & - & - & - & - & - & 1 & 1 & 0.5 & 37 \\
\hline Nephroma spp. & - & - & 29 & 3 & 3 & - & - & 1 & 4.5 & 50 \\
\hline Parmelia spp. & - & - & 2 & - & - & - & - & - & 0.2 & 12 \\
\hline Peltigera spp. & 1 & 2 & 4 & 5 & 2 & 3 & 2 & - & 2.4 & 87 \\
\hline Pleurozium schreberi & 38 & 26 & 30 & 30 & 40 & 31 & 50 & 4 & 31.1 & 100 \\
\hline Polytrichum spp. & 1 & 1 & 2 & 1 & 3 & - & - & - & 1.0 & 62 \\
\hline Ptilium spp. & - & 1 & - & - & - & - & - & - & 0.1 & 12 \\
\hline Sphagnum spp. & 40 & 30 & - & 20 & - & - & - & 70 & 20.0 & 50 \\
\hline Total & 95 & 87 & 93 & 90 & 83 & 81 & 76 & 88 & 86.6 & \\
\hline
\end{tabular}

a $\mathrm{Tr}$ indicates that the cover of a species within a plot was $<1$ percent cover. A dash indicates that the species was absent.

b $\mathrm{Tr}$ indicates that the average cover of a species was $<0.1$ of 1 percent.

\section{Table $9 \mathrm{~b}-$ Site characteristics of Kenai vegetation plots belonging to the Open Picea glauca-Picea mariana/Empetrum nigrum-Vaccinium vitis-idaea/Peltigera spp.-Pleurozium spp. community, TWINSPAN subset *0001}

\begin{tabular}{|c|c|c|c|c|c|c|c|}
\hline Plot & Elevation & $\begin{array}{l}\text { Principal } \\
\text { cover }\end{array}$ & Closure ${ }^{b}$ & $\begin{array}{l}\text { St and } \\
\text { age }\end{array}$ & $\begin{array}{l}\text { Slope } \\
\text { position }\end{array}$ & Slope & Aspect \\
\hline & Meters & & & Years & & Percent & \\
\hline 22 & 274.3 & Conifer & Open & 100 & Rolling & 13.0 & None \\
\hline 24 & 61.0 & Conifer & Open & 132 & Flat & 1.0 & $\mathrm{NW}$ \\
\hline 25 & 61.0 & Conifer & Open & 55 & Flat & 1.0 & $\mathrm{NW}$ \\
\hline 27 & 152.4 & Conifer & Open & 61 & Upper & 26.8 & NW \\
\hline 29 & 213.4 & Conifer & Open & 42 & Flat & 3.8 & $\mathrm{NW}$ \\
\hline 79 & 213.4 & Conifer & Open & 155 & Low & 11.8 & NW \\
\hline 133 & 61.0 & Mixed & Open & 139 & Rolling & 9.0 & None \\
\hline 142 & 243.8 & Conifer & Open & 141 & Mid & 6.2 & SW \\
\hline
\end{tabular}

a A stand was classified as conifer if coniferous overstory trees contributed at least 75 percent of tree cover, and similarly for hardwoods. A stand was classified as mixed if neither overstory conifers nor hardwoods contributed at least 75 percent of tree cover.

b A stand was classified as closed, open, or woodland if overstory tree cover was at least 60,25 , or 10 percent, respectively. Stands with < 10 percent cover were considered to be nonforest land.

c Stand age was calculated as the average of as many as 6 coniferous site trees. Site trees were individuals that had maintained a dominant or codominant canopy position for most of their lives. When possible, site trees were selected from those trees included in the variable-radius plots. If an insufficient number of site trees was obtained from the variable-radius plots, then additional neighboring trees meeting the site tree criterion were selected if possible.

d Possible values for slope (topographic) position were flat, low(er slope), mid(slope). upper (slope), and rolling (terrain).

e Possible values for aspect are the cardinal compass directions (N, S, E, and $W$ ) or combinations (for example, NW, SE). 
Table $9 \mathrm{c}$-Soil characteristics of Kenai vegetation plots belonging to the Open Picea glauca-Picea mariana/Empetrum nigrum-Vaccinium vitis-idaea/Peltigera spp.-Pleurozium spp. community, TWINSPAN subset *0001

\begin{tabular}{|c|c|c|c|c|c|c|c|c|c|}
\hline \multirow[b]{2}{*}{ Plot } & \multicolumn{6}{|c|}{ Depth of ${ }^{a}$} & \multicolumn{3}{|c|}{ Top mineral horizon } \\
\hline & $\begin{array}{l}\text { Impervious } \\
\text { layerb }\end{array}$ & $\begin{array}{l}\text { Saturated } \\
\text { soilb }\end{array}$ & $\begin{array}{l}\text { Root } \\
\text { depth }\end{array}$ & $\begin{array}{l}\text { Moss } \\
\text { layer }\end{array}$ & $\begin{array}{l}\text { Fibrous } \\
\text { organic }\end{array}$ & $\begin{array}{l}\text { Decomposed } \\
\text { organic }\end{array}$ & Texture ${ }^{c}$ & $\begin{array}{l}\text { Coarse } \\
\text { fragments }\end{array}$ & Depthe \\
\hline & ---- & $-\cdots$ & - Cent & imeters & $--\cdots$ & $-\cdots-$ & & & $\underline{\mathrm{Cm}}$ \\
\hline 22 & - & - & 20 & 6 & 11 & 15 & SL & VL & 43 \\
\hline 24 & - & - & 17 & 4 & 12 & 16 & SL & VL & 29 \\
\hline 25 & - & - & 10 & 3 & 6 & 9 & SL & VL & 28 \\
\hline 27 & - & - & 19 & 4 & 13 & 17 & SiL-SI & VL & 42 \\
\hline 29 & - & - & 16 & 4 & 8 & 15 & $\mathrm{~L}$ & VL & 33 \\
\hline 79 & - & - & 16 & 3 & 7 & 11 & $\mathrm{~L}$ & VL & 17 \\
\hline 133 & - & - & 22 & 3 & 6 & 10 & SiL-SL & VL & 31 \\
\hline 142 & 63 & 37 & 20 & 6 & 13 & 22 & $\mathrm{CL}$ & VL & 35 \\
\hline
\end{tabular}

a All depths were relative to the top of the moss layer on the soil surface.

b A dash indicates that a specific type of soil feature was not observed within the first 50 centimeters below the soil surface.

c soil texture was determined for each of the 5 subplots. Texture classes were $\mathrm{CL}=\mathrm{clay}$ loam,

SiL = silt loam, L = loam, $S L=$ sandy loam, and LS = loamy sand (or sand). For each plot, if the same texture class was recorded on at least 4 of the subplots, then that texture class is reported for the plot, otherwise a range of texture classes is indicated.

d The mineral fraction $>2 \mathrm{~mm}$ diameter was classed as coarse fragments. Coarse fragment content was recorded as very 10 (VL \& 15 percent), 10w (15 percent < L < 30 percent), moderate ( 30 percent < 460 percent), or high ( $H>60$ percent). 
Table $10 \mathrm{~b}$-Site characteristics of Kenai vegetation plots belonging to the Closed Picea glauca-Betula papyrifera/Vaccinium vitis-idaea/Cornus canadensis/Pleurozium spp. community, TWINSPAN subset *001

\begin{tabular}{|c|c|c|c|c|c|c|c|}
\hline Plot & Elevation & $\begin{array}{l}\text { Principal } \\
\text { cover }\end{array}$ & Closure & $\begin{array}{l}\text { Stand } \\
\text { age }\end{array}$ & $\begin{array}{l}\text { Slope } \\
\text { position }\end{array}$ & Slope & Aspec \\
\hline & Meters & & & Years & & Percent & \\
\hline 21 & 152.4 & Mixed & Open & 137 & Low & 3.4 & NW \\
\hline 28 & 182.9 & Mixed & Open & 57 & Low & 2.0 & $\mathrm{NW}$ \\
\hline 33 & 121.9 & Conifer & Closed & 151 & Low & 11.6 & SW \\
\hline 35 & 152.4 & Mixed & Closed & 97 & Mid & 11.8 & $\mathrm{NW}$ \\
\hline 36 & 121.9 & Mixed & Open & 84 & Mid & 15.4 & SW \\
\hline 37 & 121.9 & Mixed & Open & 140 & Low & 12.4 & $\mathrm{NW}$ \\
\hline 39 & 91.4 & Mixed & Closed & 97 & Flat & 1.0 & NW \\
\hline 43 & 30.5 & Conifer & Open & 122 & Rolling & 1.0 & None \\
\hline 45 & 61.0 & Mixed & Closed & 126 & Mid & 5.8 & $\mathrm{SE}$ \\
\hline 48 & 61.0 & Mixed & Closed & 47 & Low & 3.2 & $N W$ \\
\hline 49 & 91.4 & Hardwood & Open & 78 & Mid & 10.0 & SW \\
\hline 58 & 91.4 & Hardwood & Open & 124 & Mid & 7.0 & $\mathrm{SE}$ \\
\hline 64 & 152.4 & Mixed & Closed & 65 & Flat & 1.4 & None \\
\hline 66 & 121.9 & Mixed & Closed & 113 & Mid & 9.4 & $\mathrm{SE}$ \\
\hline 68 & 61.0 & Mixed & Closed & 54 & Flat & 1.0 & None \\
\hline 69 & 30.5 & Conifer & Closed & 126 & Low & 10.4 & $N W$ \\
\hline 81 & 91.4 & Mixed & Closed & 104 & Mid & $16.0=$ & SW \\
\hline 82 & 121.9 & Mixed & Open & 105 & Flat & 2.8 & None \\
\hline 115 & 91.4 & Mixed & Closed & 100 & Flat & 1.0 & None \\
\hline 119 & 121.9 & Mixed & Closed & 85 & Mid & 13.4 & SW \\
\hline 130 & 121.9 & Mixed & Closed & 81 & Rolling & 3.6 & None \\
\hline 132 & 30.5 & Mixed & Closed & 84 & Flat & 1.4 & None \\
\hline 134 & 182.9 & Conifer & Open & 75 & Mid & 2.4 & $\mathrm{NW}$ \\
\hline 138 & 152.4 & Conifer & Closed & 47 & Low & 2.4 & SW \\
\hline
\end{tabular}

a A stand was classified as conifer if coniferous overstory trees contributed at least 75 percent of tree cover, and similarly for hardwoods. A stand was classified as mixed if neither overstory conifers nor hardwoods contributed at least 75 percent of tree cover.

b A stand was classified as closed, open, or woodland if overstory tree cover was at least 60,25 , or 10 percent, respectively. Stands with < 10 percent cover were considered to be nonforest land.

c Stand age was calculated as the average of as many as 6 coniferous site trees. Site trees were individuals that had maintained a dominant or codominant canopy position for most of their lives. When possible, site trees were selected from those trees included in the variable-radius plots. If an insufficient number of site trees was obtained from the variable-radius plots, then additional neighboring trees meeting the site tree criterion were selected if possible.

d Possible values for slope (topographic) position were flat, low(er slope), mid(slope), upper (slope), and rolling (terrain).

e Possible values for aspect are the cardinal compass directions (N, S, E, and W) or combinations (for example, NW, SE). 


\begin{tabular}{|c|c|c|c|c|c|c|c|c|c|}
\hline \multirow[b]{2}{*}{ Plot } & \multicolumn{6}{|c|}{ Depth of: ${ }^{a}$} & \multicolumn{3}{|c|}{ Top mineral horizon } \\
\hline & $\begin{array}{l}\text { lmpervious } \\
\text { layerb }\end{array}$ & $\begin{array}{l}\text { Saturated } \\
\text { soilb }\end{array}$ & $\begin{array}{l}\text { Root } \\
\text { depth }\end{array}$ & $\begin{array}{l}\text { Moss } \\
\text { layer }\end{array}$ & $\begin{array}{l}\text { Fibrous } \\
\text { organic }\end{array}$ & $\begin{array}{l}\text { Decomposed } \\
\text { organic }\end{array}$ & Texture ${ }^{c}$ & $\begin{array}{l}\text { Coarse } \\
\text { fragments }\end{array}$ & Deptha \\
\hline & ----- & $--\cdots$ & - Cent & imeters & ---- & ----- & & & $\underline{\mathrm{Cm}}$ \\
\hline 21 & - & - & 15 & 3 & 8 & 12 & $\mathrm{SiL}$ & VI & 23 \\
\hline 28 & - & - & 14 & 1 & 7 & 9 & SiL & VL & 19 \\
\hline 33 & 86 & 72 & 22 & 7 & 16 & 27 & SiL-L & $V L-M$ & 34 \\
\hline 35 & - & - & 21 & 1 & 7 & 9 & SiL-L & VL & 16 \\
\hline 36 & - & - & 12 & 2 & 9 & 11 & SiL & VL & 31 \\
\hline 37 & - & - & 18 & 3 & 9 & 12 & SL-LS & VL & 39 \\
\hline 39 & - & - & 15 & 4 & 8 & 11 & SL & VI & 19 \\
\hline 43 & - & - & 13 & 3 & 8 & 12 & SiL & VI & 42 \\
\hline 45 & - & - & 23 & 4 & 6 & 8 & SiL-SL & VL & 28 \\
\hline 48 & - & - & 17 & 1 & 4 & 7 & $\mathrm{SL}$ & VL & 18 \\
\hline 49 & - & - & 17 & 1 & 4 & 6 & SiL & VL & 17 \\
\hline 58 & - & - & 15 & 3 & 7 & 11 & SI & VL & 28 \\
\hline 64 & - & 83 & 12 & 1 & 5 & 7 & SiL-SL & $V L$ & 31 \\
\hline 66 & - & - & 20 & 4 & 7 & 10 & SL-IS & VL & 41 \\
\hline 68 & - & - & 15 & 1 & 3 & 5 & SiL & VL & 29 \\
\hline 69 & - & 75 & 30 & 2 & 8 & 12 & SiL & VL & 29 \\
\hline 81 & - & - & 14 & 5 & 10 & 14 & SiL-SL & VL & 39 \\
\hline 82 & - & - & 17 & 3 & 6 & 9 & SiL-SL & VL & 15 \\
\hline 115 & - & - & 17 & 3 & 9 & 13 & SiL-SL & VL & 39 \\
\hline 119 & 67 & - & 19 & 6 & 13 & 18 & SiL-SL & $V L-M$ & 22 \\
\hline 130 & - & - & 13 & 4 & 8 & 12 & L & VL & 34 \\
\hline 132 & - & - & 19 & 2 & 6 & 10 & SL & VL & 16 \\
\hline 134 & - & - & 16 & 3 & 7 & 11 & SiL-SL & VL & 17 \\
\hline 138 & - & - & 16 & 2 & 6 & 10 & SiL-SL & VL & 30 \\
\hline
\end{tabular}

a All depths were relative to the top of the moss layer on the soil surface.

b A dash indicates that a specific type of soil feature was not observed within the first 50 centimeters below the soil surface.

c Soil texture was determined for each of the 5 subplots. Texture classes were $\mathrm{CL}=\mathrm{clay}$ loam, SiL = silt loam, $L=$ loam, $S L=$ sandy loam, and $L S=$ loamy sand (or sand). For each plot, if the same texture class was recorded on at least 4 of the subplots, then that texture class is reported for the plot, otherwise a range of texture classes is indicated.

d The mineral fraction $>2 \mathrm{~mm}$ diameter was classed as coarse fragments. Coarse fragment content was recorded as very low (VL < 15 percent), low (15 percent \& L \& 30 percent), moderate ( 30 percent < $M$ < 60 percent), or high ( $\mathrm{H}>60$ percent). 


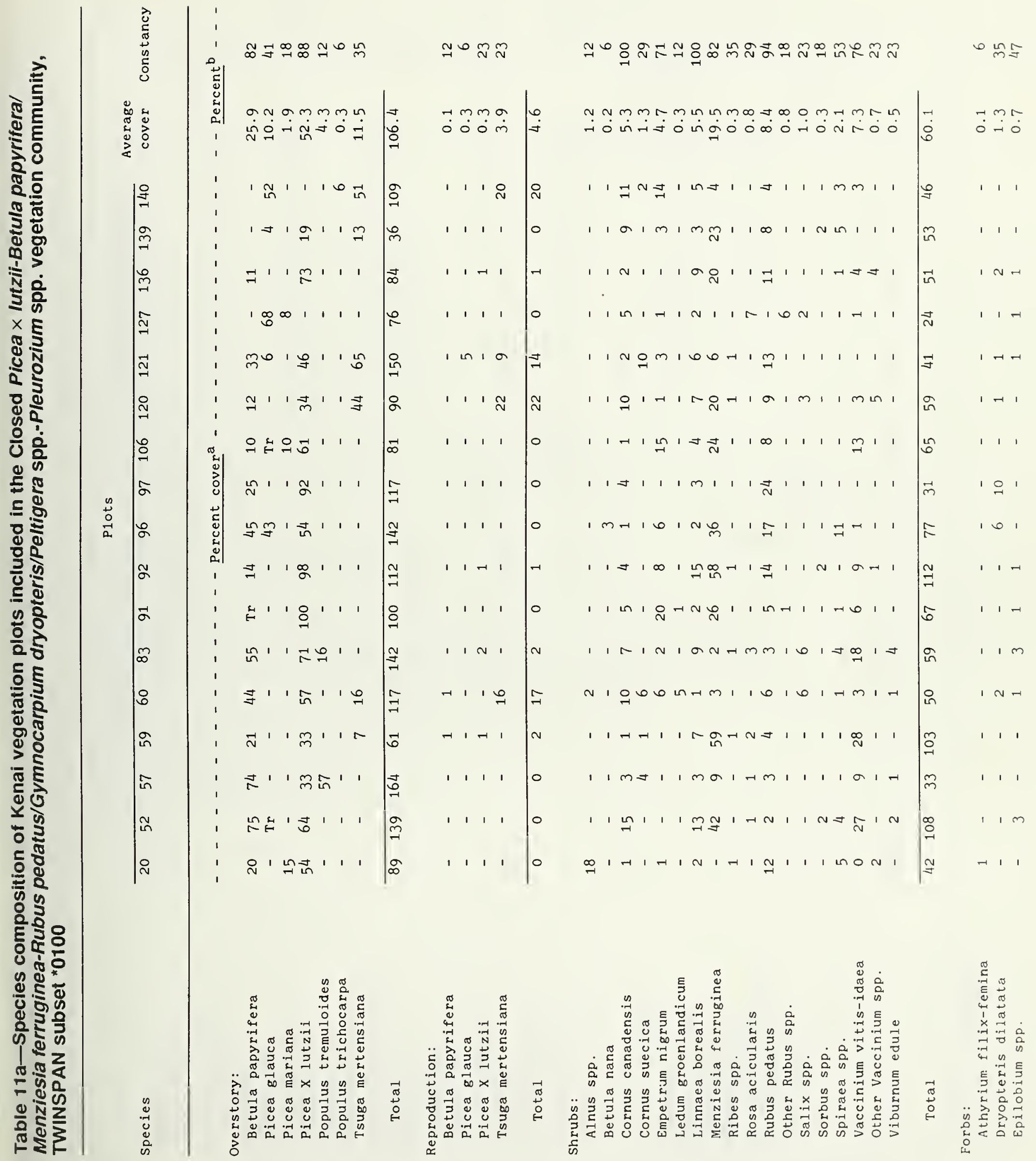




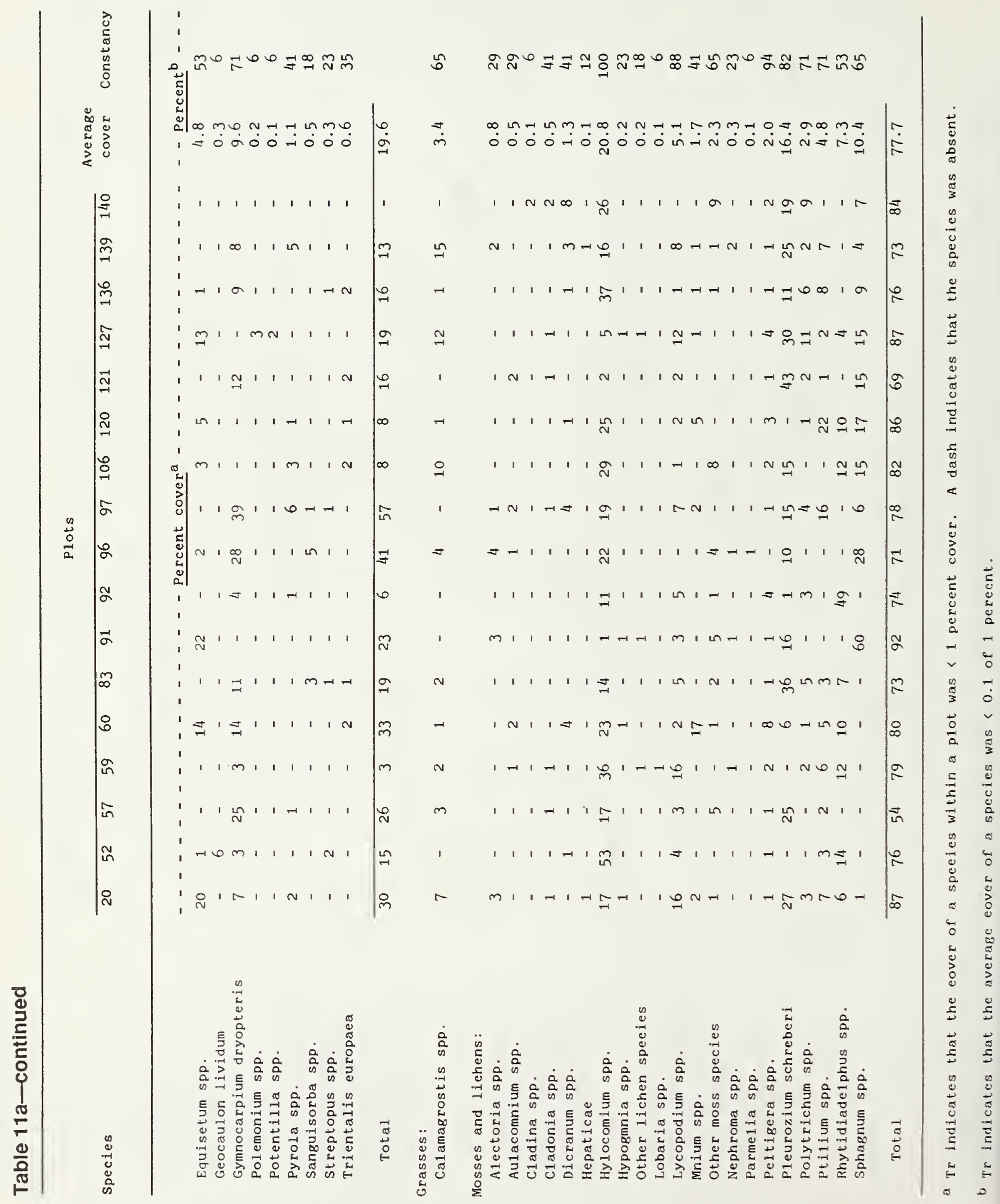


Table 11b-Site characteristics of Kenai vegetation plots belonging to the Closed Picea $\times$ lutzil-Betula papyrifera/Menziesia ferruginosaRubus pedatus/Cornus canadensis-Gymnocarpium dryopteris/ Peltigera spp.-Pleurozium spp. community, TWINSPAN subset *0100

\begin{tabular}{rrllrlrl}
\hline Plot & Elevation & $\begin{array}{l}\text { Principal } \\
\text { covera }\end{array}$ & Closure & $\begin{array}{l}\text { Stand } \\
\text { age }\end{array}$ & $\begin{array}{l}\text { Slope } \\
\text { position }\end{array}$ & Slope & Aspect \\
\hline & Meters & & & Years & & Percent & \\
& & & & & & & \\
20 & 213.4 & Conifer & Open & 125 & Low & 5.4 & NW \\
52 & 61.0 & Mixed & Open & 164 & Low & 2.4 & SW \\
57 & 91.4 & Mixed & Closed & 112 & Rolling & 7.6 & None \\
59 & 152.4 & Mixed & Open & 152 & Mid & 16.0 & SW \\
60 & 182.9 & Mixed & Closed & 102 & Mid & 42.0 & SE \\
83 & 91.4 & Mixed & Open & 84 & Mid & 6.2 & SW \\
91 & 243.8 & Conifer & Closed & 112 & Mid & 5.2 & NE \\
92 & 304.8 & Conifer & Open & 119 & Mid & 8.6 & SE \\
96 & 91.4 & Conifer & Closed & 131 & Low & 1.4 & NW \\
97 & 91.4 & Conifer & Closed & 118 & Flat & 4.4 & None \\
106 & 61.0 & Conifer & Closed & 150 & Mid & 9.6 & NW \\
120 & 152.4 & Conifer & Closed & 72 & Mid & 18.8 & SW \\
121 & 213.4 & Mixed & Closed & 61 & Mid & 21.8 & SE \\
127 & 243.8 & Conifer & Closed & 107 & Flat & 1.0 & None \\
136 & 61.0 & Conifer & Closed & 150 & Flat & 1.8 & None \\
139 & 274.3 & Conifer & Closed & 110 & Mid & 4.8 & NW \\
140 & 426.7 & Conifer & Closed & 116 & Mid & 19.2 & SW \\
\hline
\end{tabular}

a A stand was classified as conifer if coniferous overstory trees contributed at least 75 percent of tree cover, and similarly for hardwoods. A stand was classified as mixed if neither overstory conifers nor hardwoods contributed at least 75 percent of tree cover.

b A stand was classified as closed, open, or woodland if overstory tree cover was at least 60,25 , or 10 percent, respectively. Stands with< 10 percent cover were considered to be nonforest land.

c stand age was calculated as the average of as many as 6 coniferous site trees. Site trees were individuals that had maintained a dominant or codominant canopy position for most of their lives. When possible, site trees were selected from those trees included in the variable-radius plots. If an insufficient number of site trees was obtained from the variable-radius plots, then additional neighboring trees meeting the site tree criterion were selected if possible.

d Possible values for slope (topographic) position were flat, low(er slope), mid(slope), upper (slope), and rolling (terrain).

e Possible values for aspect are the cardinal compass directions (N, S, E, and W) or combinations (for example, NW, SE). 
Table 11c-Soil characteristics of Kenai vegetation plots belonging to the Closed Picea $\times$ lutzii-Betula papyrifera/Menziesia ferruginosa-Rubus pedatus/Cornus canadensis-Gymnocarpium dryopteris/Peltigera spp.-Pleurozium spp. community, TWINSPAN subset "0100

\begin{tabular}{|c|c|c|c|c|c|c|c|c|c|}
\hline \multirow[b]{2}{*}{ Plot } & \multicolumn{6}{|c|}{ Depth of: ${ }^{a}$} & \multicolumn{3}{|c|}{ Top mineral horizon } \\
\hline & $\begin{array}{l}\text { Impervious } \\
\text { layerb }\end{array}$ & $\begin{array}{l}\text { Saturated } \\
\text { soilb }\end{array}$ & $\begin{array}{l}\text { Root } \\
\text { depth }\end{array}$ & $\begin{array}{l}\text { Moss } \\
\text { layer }\end{array}$ & $\begin{array}{l}\text { Fibrous } \\
\text { organic }\end{array}$ & $\begin{array}{l}\text { Decomposed } \\
\text { organic }\end{array}$ & Texture ${ }^{c}$ & $\begin{array}{l}\text { Coarse } \\
\text { fragments }\end{array}$ & Depth ${ }^{a}$ \\
\hline & $-\cdots$ & ---- & - Cent & imeters & --- & ---- & & & $\underline{\mathrm{Cm}}$ \\
\hline 20 & - & - & 17 & 3 & 11 & 15 & SiL & VL & 41 \\
\hline 52 & - & - & 13 & 2 & 5 & 7 & $\mathbf{L}$ & VL & 12 \\
\hline 57 & - & - & 12 & 2 & 5 & 8 & SiL & VL & 30 \\
\hline 59 & - & - & 21 & 3 & 17 & 22 & $\mathrm{SL}$ & VL & 50 \\
\hline 60 & - & - & 22 & 4 & 11 & 17 & $\mathbf{L}-\mathbf{S L}$ & $\mathrm{VL}-\mathrm{M}$ & 34 \\
\hline 83 & - & - & 14 & 3 & 6 & 8 & SiL-SL & VL & 32 \\
\hline 91 & - & - & 15 & 7 & 14 & 20 & $C L-L$ & $\mathrm{VL}-\mathrm{M}$ & 42 \\
\hline 92 & - & - & 13 & 2 & 6 & 7 & SiL-L & VL & 19 \\
\hline 96 & - & - & 28 & 8 & 11 & 13 & SiL & VL & 24 \\
\hline 97 & - & - & 12 & 3 & 9 & 13 & SL & VL & 35 \\
\hline 106 & 87 & - & 19 & 6 & 13 & 17 & SiL-SL & VL & 43 \\
\hline 120 & - & 83 & 15 & 4 & 9 & 14 & CL-L & VL-M & 28 \\
\hline 121 & 81 & 88 & 17 & 2 & 6 & 11 & SL & $\mathrm{VL}-\mathrm{M}$ & 34 \\
\hline 127 & - & 89 & 21 & 5 & 13 & 18 & $\mathrm{~L}$ & VL & 42 \\
\hline 136 & - & - & 15 & 5 & 12 & 15 & SiL & VL & 27 \\
\hline 139 & - & - & 19 & 3 & 7 & 10 & SiL & $\mathrm{VL}-\mathrm{M}$ & 32 \\
\hline 140 & - & - & 18 & 2 & 4 & 7 & SiL & VL-L & 17 \\
\hline
\end{tabular}

a Al depths were relative to the top of the moss layer on the soil surface.

b A dash indicates that a specific type of soil feature was not observed within the first 50 centimeters below the soil surface.

C Soil texture was determined for each of the 5 subplots. Texture classes were CL $=$ clay loam,

SiL = silt loam, $L=$ loam, and $S L=$ sandy loam (or sand). For each plot, if the same texture class was recorded on at least 4 of the subplots, then that texture class is reported for the plot, otherwise a range of texture classes is indicated.

d The mineral fraction > $2 \mathrm{~mm}$ diameter was classed as coarse fragments. Coarse fragment content was recorded as very low (VL < 15 percent), low (15 percent< $L$ < 30 percent), moderate ( 30 percent < M 60 percent), or high (H>60 percent). 


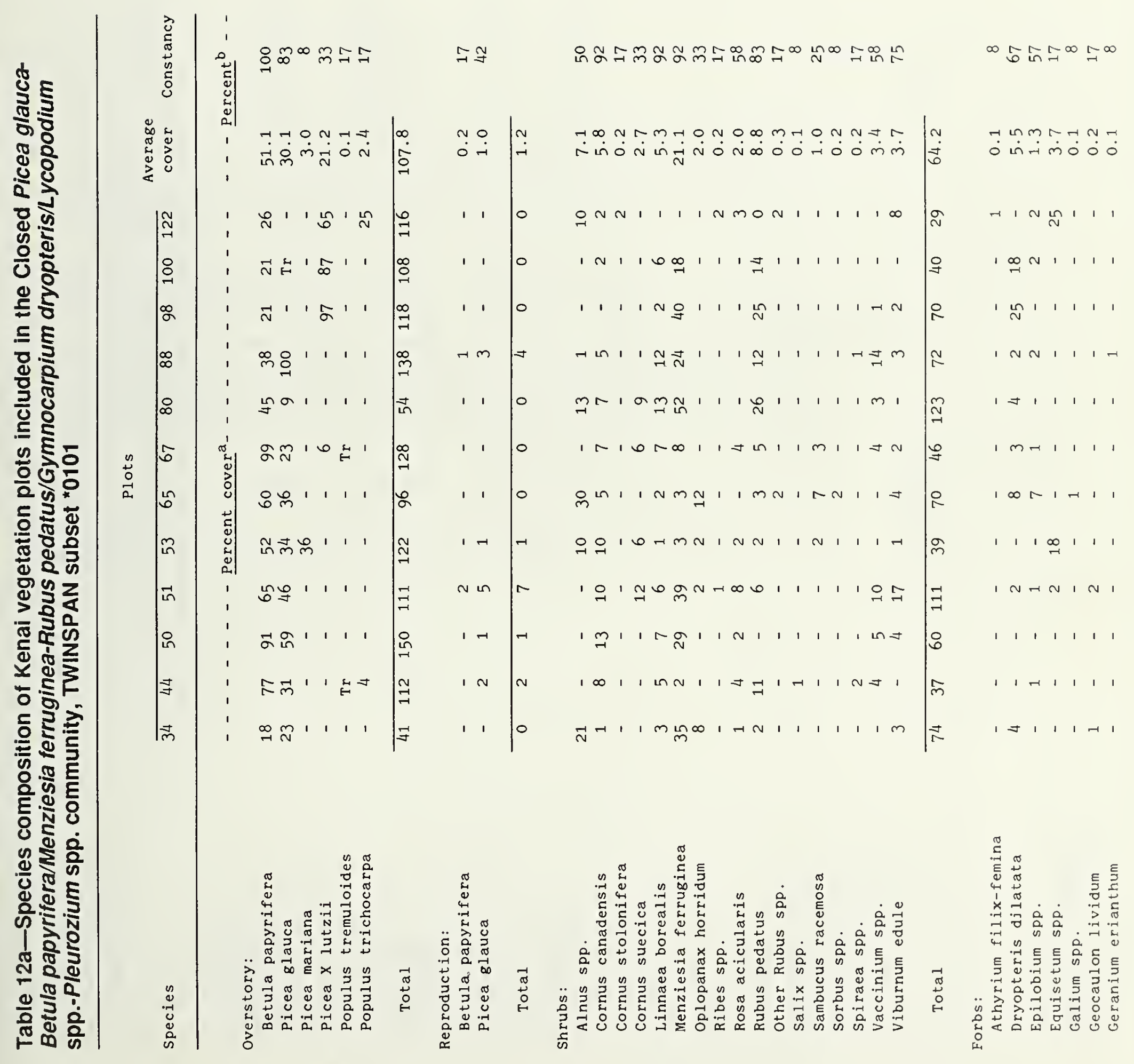




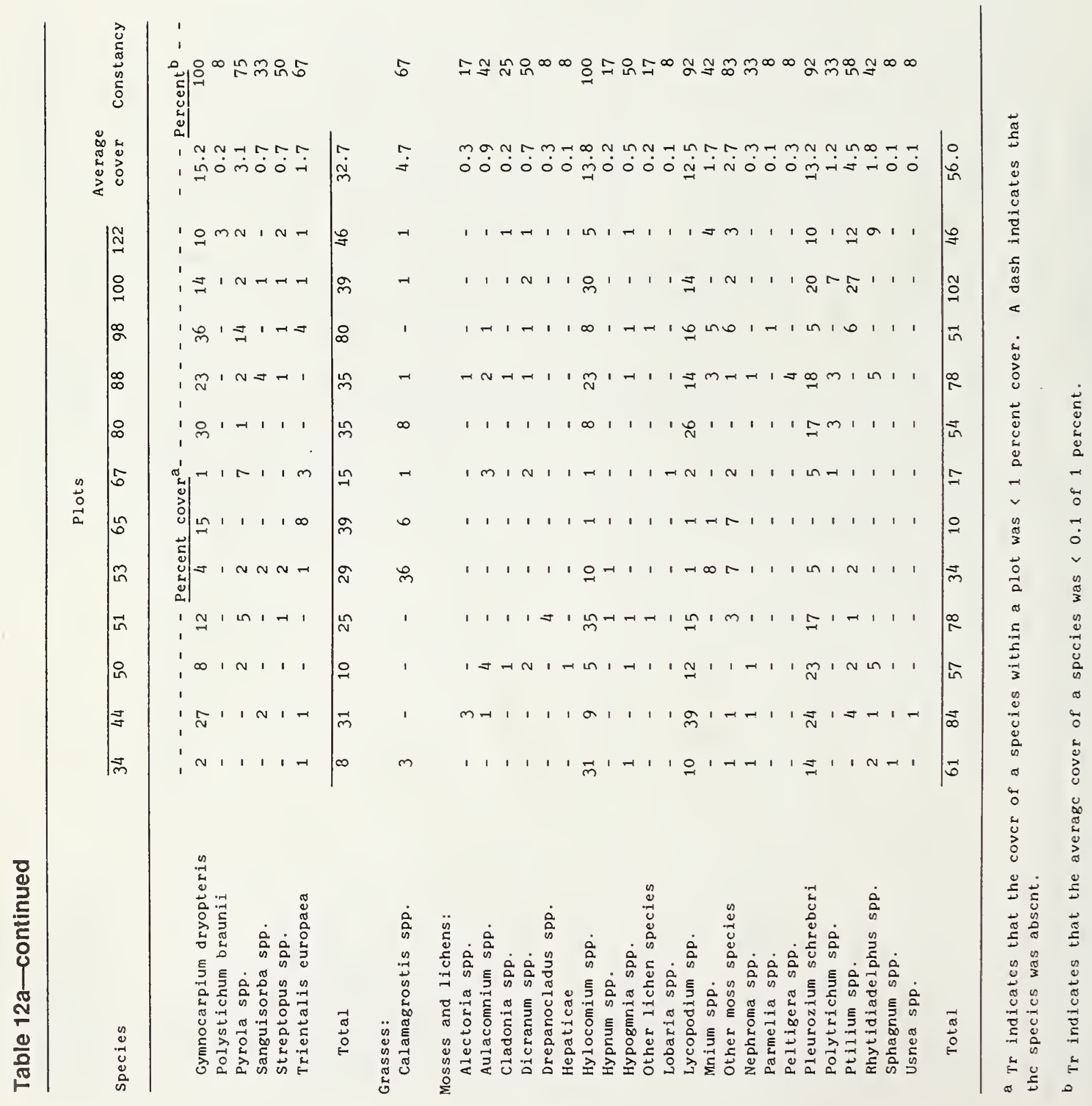


Table $12 \mathrm{~b}$-Site characteristics of Kenai vegetation plots belonging to the Closed Picea glauca-Betula papyrifera/Menziesia ferruginea-Rubus pedatus/Gymnocarpium dryopteris/Lycopodium spp.-Pleurozium spp. community, TWINSPAN subset *0101

\begin{tabular}{|c|c|c|c|c|c|c|c|}
\hline Plot & Elevation & $\begin{array}{l}\text { Principal } \\
\text { cover }{ }^{\mathrm{a}}\end{array}$ & Closure & $\begin{array}{l}\text { Stand } \\
\text { age }\end{array}$ & $\begin{array}{l}\text { Slope } \\
\text { position }\end{array}$ & Slope & Aspect \\
\hline & Meters & & & Years & & Percent & \\
\hline 34 & 243.8 & Conifer & Closed & 119 & Mid & 48.8 & $\mathrm{SE}$ \\
\hline 44 & 30.5 & Mixed & Closed & 100 & Rolling & 1.0 & None \\
\hline 50 & 61.0 & Hardwood & Closed & 81 & Rolling & 3.4 & None \\
\hline 51 & 61.0 & Mixed & Open & 138 & Low & 3.2 & SW \\
\hline 53 & 61.0 & Mixed & Open & 104 & Flat & 1.0 & None \\
\hline 65 & 121.9 & Mixed & Open & 118 & Mid & 14.6 & SW \\
\hline 67 & 121.9 & Hardwood & Closed & 60 & Mid & 12.4 & $\mathrm{SE}$ \\
\hline 80 & 182.9 & Mixed & Open & $\mathrm{NA}$ & Mid & 25.0 & SW \\
\hline 88 & 152.4 & Mixed & Closed & 87 & Mid & 14.4 & $\mathrm{NW}$ \\
\hline 98 & 91.4 & Conifer & Closed & 112 & Low & 6.0 & $\mathrm{NW}$ \\
\hline 100 & 61.0 & Conifer & Closed & 125 & Low & 13.0 & SW \\
\hline 122 & 152.4 & Mixed & Closed & 92 & Flat & 1.0 & None \\
\hline
\end{tabular}

a A stand was classified as conifer if coniferous overstory trees contributed at least 75 percent of tree cover, and similarly for hardwoods. A stand was classified as mixed if neither overstory conifers nor hardwoods contributed at least 75 percent of tree cover.

b A stand was classified as closed, open, or woodland if overstory tree cover was at least 60,25 , or 10 percent, respectively. Stands with \& 10 percent cover were considered to be nonforest 1 and.

c Stand age was calculated as the average of as many as 6 coniferous site trees. Site trees were individuals that had maintained a dominant or codominant canopy position for most of their lives. When possible, site trees were selected from those trees included in the variable-radius plots. If an insufficient number of site trees was obtained from the variable-radius plots, then additional neighboring trees meeting the site tree criterion were selected if possible.

d Possible values for slope (topographic) position were flat, low(er slope), mid(slope). upper (slope), and rolling (terrain).

e Possible values for aspect are the cardinal compass directions (N, S, E, and W) or combinations (for example. NW. SE). 
Table 12c-Soil characteristics of Kenai vegetation plots belonging to the Closed Picea glauca-Betula papyrifera/Menziesia ferruginea-Rubus pedatus/Gymnocarpium dryopteris/ Lycopodium spp.-Pleurozium spp. community, TWINSPAN subset *0101

\begin{tabular}{|c|c|c|c|c|c|c|c|c|c|}
\hline \multirow[b]{2}{*}{ Plot } & \multicolumn{6}{|c|}{ Depth of: ${ }^{a}$} & \multicolumn{3}{|c|}{ Top mineral horizon } \\
\hline & $\begin{array}{l}\text { Impervious } \\
\text { layerb }\end{array}$ & $\begin{array}{l}\text { Saturated } \\
\text { soil b }\end{array}$ & $\begin{array}{l}\text { Root } \\
\text { depth }\end{array}$ & $\begin{array}{l}\text { Moss } \\
\text { layer }\end{array}$ & $\begin{array}{l}\text { Fibrous } \\
\text { organic }\end{array}$ & $\begin{array}{l}\text { Decomposed } \\
\text { organic }\end{array}$ & Texture ${ }^{c}$ & $\begin{array}{l}\text { Coarse } \\
\text { fragments }\end{array}$ & Depth \\
\hline & $-\ldots--$ & ---- & - Cen & imeters & ---- & ----- & & & $\underline{\mathrm{Cm}}$ \\
\hline 34 & 52 & - & 22 & 4 & 10 & 15 & SL & $\mathrm{VL}-\mathrm{H}$ & 38 \\
\hline 44 & - & - & 12 & 2 & 7 & 13 & $\mathrm{CL}-\mathrm{SL}$ & VL & 31 \\
\hline 50 & - & - & 12 & 3 & 6 & 9 & SL & VL & 41 \\
\hline 51 & - & - & 17 & 2 & 7 & 10 & SL & VL & 37 \\
\hline 53 & - & 31 & 13 & 4 & 15 & 20 & $C L-L$ & VL-L & 31 \\
\hline 65 & - & - & 20 & 1 & 7 & 11 & SL-LS & VL & 33 \\
\hline 67 & - & - & 24 & 1 & 6 & 9 & SL & VL & 40 \\
\hline 80 & - & - & 18 & 3 & 11 & 15 & SL & VL & 27 \\
\hline 88 & - & - & 17 & 3 & 8 & 12 & SiL-SL & VL & 40 \\
\hline 98 & - & 89 & 15 & 4 & 13 & 14 & SL & VL & 43 \\
\hline 100 & - & - & 14 & 2 & 4 & 9 & SL & VL & 36 \\
\hline 122 & - & - & 21 & 3 & 5 & 8 & SiL-LS & VL & 15 \\
\hline
\end{tabular}

a All depths were relative to the top of the moss layer on the soil surface.

b A dash indicates that a specific type of soil feature was not observed within the first 50 centimeters below the soil surface.

c Soil texture was determined for each of the 5 subplots. Texture classes were CL = clay loam, SiL = silt loam, $L=$ loam, SL = sandy loam, and LS = loamy sand (or sand). For each plot, if the same texture class was recorded on at least 4 of the subplots, then that texture class is reported for the plot, otherwise a range of texture classes is indicated.

d The mineral fraction > $2 \mathrm{~mm}$ diameter was classed as coarse fragments. Coarse fragment content was recorded as very low (VL < 15 percent), low (15 percent < L < 30 percent), moderate ( 30 percent < < 60 percent), or high (H>60 percent). 


\begin{tabular}{|c|c|c|c|c|c|c|c|c|c|c|c|}
\hline \multirow[b]{2}{*}{ Species } & \multicolumn{9}{|c|}{ Plots } & \multirow{2}{*}{$\begin{array}{c}\text { Average } \\
\text { cover }\end{array}$} & \multirow[b]{2}{*}{ Constancy } \\
\hline & 18 & 19 & 26 & 70 & 84 & 85 & 87 & 94 & 102 & & \\
\hline & - & -- & - & Per & ent & cover & $a_{-}-$ & - - & - - & - $-\operatorname{Perc}$ & ent ${ }^{b}--$ \\
\hline \multicolumn{12}{|l|}{ Overstory: } \\
\hline Betula papyrifera & 80 & 11 & $\mathrm{Tr}$ & 8 & 3 & 14 & 89 & 10 & 21 & 26.2 & 100 \\
\hline Picea glauca & - & - & 100 & 55 & 59 & 96 & - & - & - & 34.4 & 44 \\
\hline Picea sitchensis & - & - & - & - & - & - & - & 74 & - & 8.2 & 11 \\
\hline Picea X lutzii & 51 & 98 & $\operatorname{Tr}$ & - & 36 & - & 37 & - & 95 & $35 \cdot 3$ & 67 \\
\hline Populus tremuloides & - & - & 36 & 5 & - & - & - & - & - & 4.5 & 22 \\
\hline Total & 131 & 109 & 137 & 68 & 98 & 110 & 126 & 84 & 116 & 108.8 & \\
\hline \multicolumn{12}{|l|}{ Reproduction: } \\
\hline Betula papyrifera & - & - & - & 11 & 3 & - & - & - & 1 & 1.7 & 33 \\
\hline Picea glauca & - & - & - & 4 & - & - & - & - & - & 0.4 & 11 \\
\hline Picea X lutzii & - & 1 & - & - & 5 & - & 1 & - & 1 & 0.9 & 44 \\
\hline Total & 0 & 1 & 0 & 15 & 8 & 0 & 1 & 0 & 2 & 3.0 & \\
\hline \multicolumn{12}{|l|}{ Shrubs: } \\
\hline Betula nana & - & - & - & 1 & 6 & - & - & - & - & 0.8 & 22 \\
\hline Cornus canadensis & 3 & 6 & 2 & 8 & 8 & - & 4 & - & 4 & 3.9 & 78 \\
\hline Cornus suecica & - & - & 3 & 2 & - & - & 2 & - & - & 0.8 & 33 \\
\hline Empet rum nigrum & - & - & 1 & 3 & 14 & - & - & - & - & 2.0 & 33 \\
\hline Linnaea borealis & 6 & 15 & 9 & 10 & 6 & 5 & 4 & 1 & 16 & 8.0 & 100 \\
\hline Menziesia ferruginea & - & - & 6 & - & - & - & - & - & - & 0.7 & 11 \\
\hline Ribes spp. & - & 4 & - & 4 & - & 1 & - & 1 & 2 & $1 \cdot 3$ & 55 \\
\hline Rubus pedatus & 26 & 17 & 6 & 10 & 8 & 30 & 16 & 4 & 28 & 16.1 & 100 \\
\hline Other Rubus spp. & - & - & 1 & - & 5 & - & - & 3 & 1 & 1.1 & 44 \\
\hline Salix spp. & - & - & 2 & 8 & 28 & - & - & - & - & 4.2 & 33 \\
\hline Sambucus racemosa & - & - & 1 & - & - & - & - & - & - & 0.1 & 11 \\
\hline Spiraea spp. & 1 & 1 & 1 & 9 & 10 & - & - & - & 3 & 2.8 & 67 \\
\hline Vaccinium spp. & - & 5 & 5 & 8 & 14 & - & - & - & 3 & 3.9 & 55 \\
\hline Viburnum edule & - & - & - & - & - & 6 & 2 & - & - & 0.9 & 22 \\
\hline Total & 36 & 48 & 37 & 63 & 99 & 42 & 28 & 9 & 57 & 46.6 & \\
\hline \multicolumn{12}{|l|}{ Forbs: } \\
\hline Achillea spp. & - & - & 1 & - & - & - & - & - & - & 0.1 & 11 \\
\hline Athyrium filix-femina & - & 2 & - & - & - & - & - & - & - & 0.2 & 11 \\
\hline Dryopteris dilatata & 1 & 8 & - & - & - & 13 & 9 & 17 & 7 & 6.1 & 67 \\
\hline Epilobium spp. & 3 & 5 & 1 & 4 & 4 & 1 & 2 & 2 & 4 & 2.9 & 100 \\
\hline Equisetum spp. & 1 & 1 & - & 1 & - & 1 & 6 & 3 & 2 & 1.7 & 78 \\
\hline Geocaulon lividum & - & 1 & - & - & - & - & - & - & - & 0.1 & 11 \\
\hline Geranium erianthum & 1 & 2 & 1 & - & - & 1 & - & 1 & 4 & 1.1 & 67 \\
\hline Gymnocarpium dryopteris & 49 & 12 & 6 & 3 & 12 & 26 & 18 & 19 & 10 & 17.2 & 100 \\
\hline Lupinus spp. & - & - & - & - & - & - & - & 1 & - & $\Rightarrow \quad 0.1$ & 11 \\
\hline Pyrola spp. & 2 & - & 1 & - & 1 & 3 & 7 & - & 2 & 1.7 & 67 \\
\hline Sanguisorba spp. & 3 & 2 & 11 & 3 & 2 & 4 & 6 & 19 & 15 & 7.2 & 100 \\
\hline Streptopus spp. & - & 2 & - & - & - & 4 & 5 & 1 & 4 & 1.8 & 55 \\
\hline Trientalis europaea & 1 & - & 1 & - & - & 1 & - & - & - & 0.3 & 33 \\
\hline Total & 61 & 35 & 22 & 11 & 21 & 54 & 51 & 63 & 48 & 40.7 & \\
\hline \multicolumn{12}{|l|}{ Grasses: } \\
\hline Calamagrostis spp. & 7 & 3 & 10 & 37 & 3 & 7 & 11 & 8 & 1 & 9.7 & 100 \\
\hline \multicolumn{12}{|l|}{ Mosses and Iichens: } \\
\hline Alectoria spp. & - & 1 & - & 2 & - & 1 & 1 & - & - & 0.5 & 44 \\
\hline Aulacomnium spp. & 2 & - & 1 & - & - & - & 1 & 1 & - & 0.5 & 44 \\
\hline Cladonia spp. & - & 1 & - & - & - & - & 1 & - & 1 & 0.3 & 11 \\
\hline
\end{tabular}




\begin{tabular}{|c|c|c|c|c|c|c|c|c|c|c|c|}
\hline \multirow[b]{2}{*}{ Species } & \multicolumn{9}{|c|}{ Plots } & \multirow{2}{*}{$\begin{array}{c}\text { Average } \\
\text { cover }\end{array}$} & \multirow[b]{2}{*}{ Constancy } \\
\hline & 18 & 19 & 26 & 70 & 84 & 85 & 87 & 94 & 102 & & \\
\hline & -- & - & - & - Per & ent & cover & - & -- & -- & - Per & ent $^{b}--$ \\
\hline \multicolumn{12}{|l|}{ Mosses and lichens: } \\
\hline Dicranum spp. & - & 1 & - & - & 2 & 1 & 2 & 2 & 1 & 1.0 & 67 \\
\hline Hepaticae & - & - & - & - & - & - & 1 & 1 & - & 0.2 & 22 \\
\hline Hylocomium spp. & 10 & 40 & 30 & 8 & 7 & 21 & 4 & 20 & 22 & 18.0 & 100 \\
\hline Hypnum spp. & - & - & - & - & - & - & 3 & 5 & - & 0.9 & 22 \\
\hline Hypogmnia spp. & - & - & 1 & 3 & - & 1 & - & 1 & - & 0.7 & 44 \\
\hline Other lichen species & - & - & - & - & - & 1 & - & - & - & 0.1 & 11 \\
\hline Lobaria spp. & 1 & - & - & - & - & - & - & - & - & 0.1 & 11 \\
\hline Lycopodium spp. & 26 & 18 & 2 & 25 & 1 & 8 & 23 & - & 4 & 11.9 & 89 \\
\hline Mnium spp. & - & 1 & 3 & 4 & - & 9 & 1 & 9 & 2 & 3.2 & 78 \\
\hline Other moss species & 2 & - & 2 & - & - & 2 & - & - & - & 0.7 & 33 \\
\hline Nephroma spp. & - & - & 2 & - & 1 & 1 & - & - & - & 0.4 & 33 \\
\hline Peltigera spp. & - & 1 & - & - & 1 & 1 & - & 1 & 1 & 0.5 & 55 \\
\hline Pleurozium schreberi & 10 & - & 22 & 15 & 39 & 8 & 7 & 37 & - & $15 \cdot 3$ & 78 \\
\hline Polytrichum spp. & 5 & 1 & 10 & 4 & 25 & - & - & - & 1 & 5.1 & 67 \\
\hline Ptilium spp. & 1 & 8 & 3 & 22 & 6 & 8 & 4 & 1 & 4 & 6.3 & 100 \\
\hline Rhytidiadelphus spp. & - & 6 & 12 & - & - & 4 & 4 & 6 & 29 & 6.8 & 67 \\
\hline Sphagnum spp. & - & - & - & - & - & - & - & - & 11 & 1.2 & 11 \\
\hline Total & 57 & 78 & 88 & 83 & 82 & 66 & 52 & 84 & 76 & 74.0 & \\
\hline
\end{tabular}

a Tr indicates that the cover of a species within a plot was 1 percent cover. A dash indicates that the species was absent.

b $\operatorname{Tr}$ indicates that the average cover of a species was $<0.1$ of 1 percent. 
Table 13b-Site characteristics of Kenai vegetation plots belonging to the Closed Picea glauca-Picea $\times$ lutzii/Linnea borealis-Rubus pedatus/ Sanguisorba spp.-Calamagrostis spp./Lycopodium spp.-Ptilium spp. community, TWINSPAN subset *0110

\begin{tabular}{|c|c|c|c|c|c|c|c|}
\hline Plot & Elevation & $\begin{array}{l}\text { Principal } \\
\text { cover }^{\mathrm{a}}\end{array}$ & Closure $\mathrm{b}^{\mathrm{b}}$ & $\begin{array}{l}\text { Stand } \\
\text { age }\end{array}$ & $\begin{array}{l}\text { Slope } \\
\text { position }\end{array}$ & Slope & Aspect \\
\hline & Meters & & & Years & & $\underline{\text { Percent }}$ & \\
\hline 18 & 91.4 & Mixed & Closed & 86 & Flat & 1.2 & None \\
\hline 19 & 243.8 & Mixed & Open & 93 & Low & 3.2 & $N W$ \\
\hline 26 & 152.4 & Mixed & Closed & 63 & Mid & 16.0 & SW \\
\hline 70 & 30.5 & Conifer & Open & 93 & Flat & 1.0 & None \\
\hline 84 & 61.0 & Conifer & Open & 112 & Low & 4.0 & NW \\
\hline 85 & 121.9 & Mixed & Open & 107 & Mid & 4.4 & $\mathrm{SE}$ \\
\hline 87 & 121.9 & Mixed & Open & 137 & Mid & 7.0 & NW \\
\hline 94 & 243.8 & Conifer & Open & 84 & Mid & 37.2 & $\mathrm{SE}$ \\
\hline 102 & 274.3 & Conifer & Open & 116 & Flat & 1.4 & None \\
\hline
\end{tabular}

a A stand was classified as conifer if coniferous overstory trees contributed at least 75 percent of tree cover, and similarly for hardwoods. A stand was classified as mixed if neither overstory conifers nor hardwoods contributed at 1 east 75 percent of tree cover.

b A stand was classified as closed, open, or woodland if overstory tree cover was at least 60,25 , or 10 percent, respectively. Stands with < 10 percent cover were considered to be nonforest land.

C Stand age was calculated as the average of as many as 6 coniferous site trees. Site trees were individuals that had maintained a dominant or codominant canopy position for most of their lives. When possible, site trees were selected from those trees included in the variable-radius plots. If an insufficient number of site trees was obtained from the variable-radius plots, then additional neighboring trees meeting the site tree criterion were selected if possible.

d Possible values for slope (topographic) position were flat, low(er slope), mid(slope), upper (slope), and rolling (terrain).

e Possible values for aspect are the cardinal compass directions (N, S, E, and W) or combinations (for example, NW, SE). 
Table 13c-Soil characteristics of Kenai vegetation plots belonging to the Closed Picea glauca-Picea $\times$ Iutzii/Linnea borealis-Rubus pedatus/Sanguisorba spp.-Calamagrostis spp./Lycopodium spp.-Ptilium spp. community, TWINSPAN subset *0110

\begin{tabular}{|c|c|c|c|c|c|c|c|c|c|}
\hline \multirow[b]{2}{*}{ Plot } & \multicolumn{6}{|c|}{ Depth of: ${ }^{a}$} & \multicolumn{3}{|c|}{ Top mineral horizon } \\
\hline & $\begin{array}{l}\text { Impervious } \\
\text { layerb }\end{array}$ & $\begin{array}{l}\text { Saturated } \\
\text { soil }\end{array}$ & $\begin{array}{l}\text { Root } \\
\text { depth }\end{array}$ & $\begin{array}{l}\text { Moss } \\
\text { layer }\end{array}$ & $\begin{array}{l}\text { Fibrous } \\
\text { organic }\end{array}$ & $\begin{array}{l}\text { Decomposed } \\
\text { organic }\end{array}$ & Texture ${ }^{c}$ & $\begin{array}{l}\text { Coarse } \\
\text { fragments }\end{array}$ & Depth ${ }^{a}$ \\
\hline & ----- & $---\cdot$ & - Cent & imeters & --- & ----- & & & $\mathrm{Cm}$ \\
\hline 18 & - & - & 11 & 1 & 5 & 7 & SiL-SL & vL & 19 \\
\hline 19 & - & - & 15 & 3 & 6 & 9 & SiL & VL & 16 \\
\hline 26 & - & - & 22 & 3 & 8 & 11 & SL & VL & 43 \\
\hline 70 & - & - & 14 & 4 & 12 & 13 & SiL-SL & VL & 40 \\
\hline 84 & - & - & 18 & 4 & 12 & 10 & SiL-SL & VL & 39 \\
\hline 85 & - & - & 17 & 2 & 5 & 10 & SL & VL & 41 \\
\hline 87 & - & - & 12 & 2 & 6 & 10 & SiL-L & VI & 40 \\
\hline 94 & - & - & 16 & 1 & 5 & 8 & $\mathrm{CL}-\mathrm{SL}$ & vL & 35 \\
\hline 102 & - & - & 9 & 2 & 5 & 8 & $\mathrm{CL}$ & VL & 34 \\
\hline
\end{tabular}

a Al depths were relative to the top of the moss layer on the soil surface.

b A dash indicates that a specific type of soil feature was not observed within the first 50 centimeters below the soil surface.

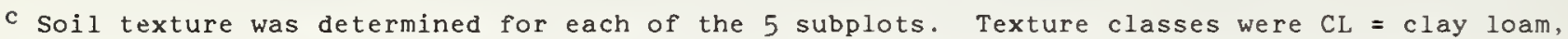

SiL = silt loam, L = loam. SL = sandy loam, and LS = loamy sand (or sand). For each plot, if the same texture class was recorded on at least 4 of the subplots, then that texture class is reported for the plot, otherwise a range of texture classes is indicated.

d The mineral fraction > $2 \mathrm{~mm}$ diameter was classed as coarse fragments. Coarse fragment content was recorded as very low (VL < 15 percent), low (15 percent< $L$ < 30 percent), moderate ( 30 percent < 3 < 60 percent), or high ( $H>60$ percent). 


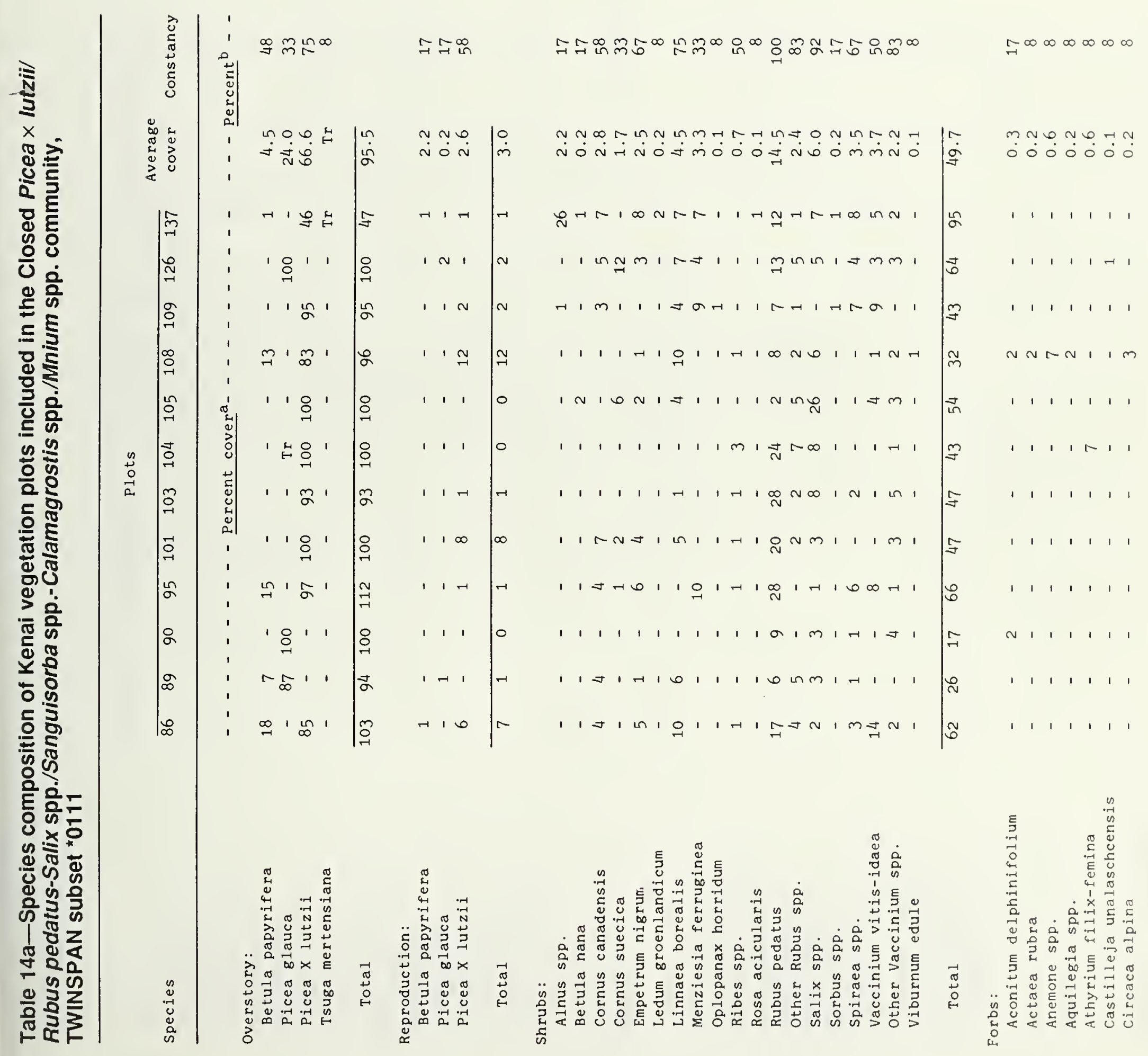




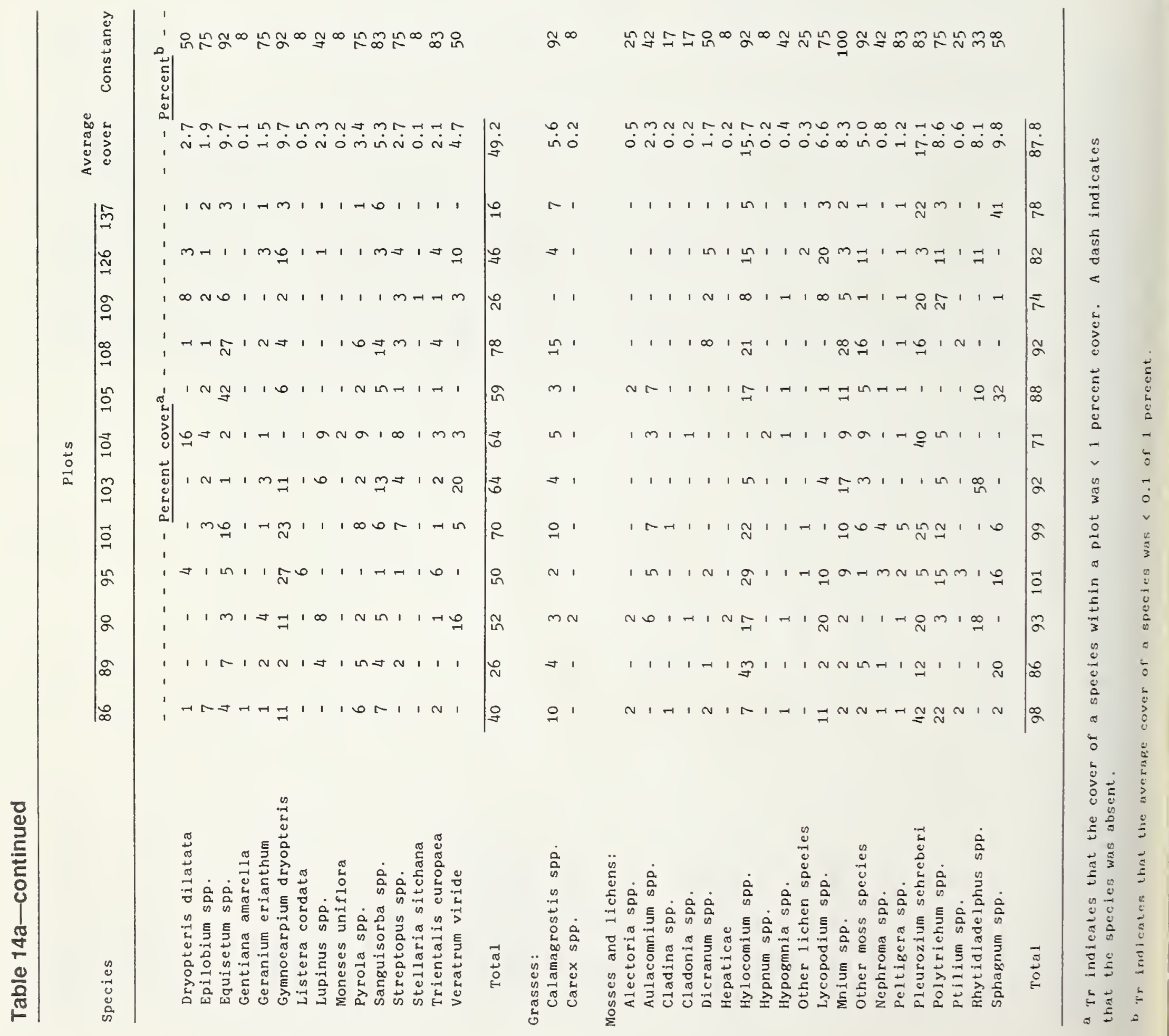


Table $14 \mathrm{~b}-$ Site characteristics of Kenai vegetation plots belonging to the Closed Picea $\times$ Iutzii/Rubus pedatus-Salix spp./Sanguisorba spp.Calamagrostis spp./Mnium spp. community, TWINSPAN subset *0111

\begin{tabular}{|c|c|c|c|c|c|c|c|}
\hline Plot & Elevation & $\begin{array}{l}\text { Principal } \\
\text { cover }\end{array}$ & $C l o s u r e^{b}$ & $\begin{array}{l}\text { Stand } \\
\text { age }\end{array}$ & $\begin{array}{l}\text { Slope } \\
\text { position }\end{array}$ & Slope & Aspect \\
\hline & Meters & & & Years & & Percent & \\
\hline 86 & 152.4 & Conifer & Open & 108 & Flat & 4.8 & None \\
\hline 89 & 365.8 & Cunifer & Closed & 144 & Mid & 39.6 & SW \\
\hline 90 & 457.2 & Conifer & Open & 99 & Flat & 1.0 & None \\
\hline 95 & 182.9 & Conifer & Closed & 107 & Mid & 32.0 & NW \\
\hline 101 & 365.8 & Conifer & Open & 108 & Flat & 4.8 & None \\
\hline 103 & 487.7 & Conifer & Open & 114 & Mid & 6.0 & NE \\
\hline 104 & 457.2 & Conifer & Closed & 94 & Mid & 6.2 & SW \\
\hline 105 & 396.2 & Conifer & Closed & 119 & Mid & 4.6 & SW \\
\hline 108 & 213.4 & Mixed & Closed & 90 & Mid & 8.2 & SW \\
\hline 109 & 304.8 & Conifer & Closed & 118 & Flat & 2.8 & None \\
\hline 126 & 457.2 & Conifer & Open & 87 & Mid & 15.0 & NW \\
\hline 137 & 335.3 & Conifer & Open & 120 & Mid & 8.6 & SW \\
\hline
\end{tabular}

a A stand was classified as conifer if coniferous overstory trees contributed at least 75 percent of tree cover, and similarly for hardwoods. A stand was classified as mixed if neither overstory conifers nor hardwoods contributed at least 75 percent of tree cover.

b A stand was classified as closed, open, or woodland if overstory tree cover was at least 60,25 , or 10 percent, respectively. Stands with < 10 percent cover were considered to be nonforest land.

c stand age was calculated as the average of as many as 6 coniferous site trees. Site trees were individuals that had maintained a dominant or codominant canopy position for most of their lives. When possible, site trees were selected from those trees included in the variable-radius plots. If an insufficient number of site trees was obtained from the variable-radius plots, then additional neighboring trees meeting the site tree criterion were selected if possible.

d Possible values for slope (topographic) position were flat, low(er slope), mid(slope), upper (slope), and rolling (terrain).

e Possible values for aspect are the cardinal compass directions (N, S, E, and W) or combinations (for example, NW, SE). 
Table 14c-Soil characteristics of Kenai vegetation plots belonging to the Closed

Picea $\times$ Iutzii/Rubus pedatus-Salix spp./Sanguisorba spp.-Calamagrostis spp./

Mnium spp. community, TWINSPAN subset *0111

\begin{tabular}{|c|c|c|c|c|c|c|c|c|c|}
\hline \multirow[b]{2}{*}{ Plot } & \multicolumn{6}{|c|}{ Depth of $:^{a}$} & \multicolumn{3}{|c|}{ Top mineral horizon } \\
\hline & $\begin{array}{l}\text { Impervious } \\
\text { layer b }\end{array}$ & $\begin{array}{l}\text { Saturated } \\
\text { soilb }\end{array}$ & $\begin{array}{l}\text { Root } \\
\text { depth }\end{array}$ & $\begin{array}{l}\text { Moss } \\
\text { layer }\end{array}$ & $\begin{array}{l}\text { Fibrous } \\
\text { organic }\end{array}$ & $\begin{array}{l}\text { Decomposed } \\
\text { organic }\end{array}$ & Texture ${ }^{c}$ & $\begin{array}{l}\text { Coarse } \\
\text { fragments }\end{array}$ & Deptha \\
\hline & $---\cdot-$ & ---- & - Cent & meters & --- & $-\cdots--$ & & & $\underline{\mathrm{Cm}}$ \\
\hline 86 & - & - & 19 & 6 & 9 & 12 & SiL-SL & VL & 22 \\
\hline 89 & - & - & 18 & 5 & 7 & 11 & SiL-SL & VL & 38 \\
\hline 90 & - & - & 11 & 3 & 6 & 10 & SiL & VL & 45 \\
\hline 95 & - & - & 25 & 7 & 12 & 18 & SiL & VL & 28 \\
\hline 101 & - & - & 14 & 3 & 5 & 9 & CL-SiL & VL & 19 \\
\hline 103 & - & - & 16 & 2 & 4 & 5 & SiL-L & VL & 25 \\
\hline 104 & - & - & 12 & 4 & 6 & 10 & SiL-SL & VL & 42 \\
\hline 105 & 55 & 49 & 15 & 2 & 5 & 8 & SiL-L & VL & 25 \\
\hline 108 & - & - & 17 & 2 & 6 & 11 & $\mathrm{CL}-\mathrm{SL}$ & $V L-M$ & 37 \\
\hline 109 & - & - & 18 & 3 & 5 & 7 & SiL & VL & 14 \\
\hline 126 & - & - & 17 & 2 & 5 & 8 & SiL-SL & VL & 21 \\
\hline 137 & 81 & 86 & 15 & 1 & 7 & 9 & $\mathrm{SiL}$ & VL & 24 \\
\hline
\end{tabular}

a A11 depths were relative to the top of the moss layer on the soil surface.

b A dash indicates that a specific type of soil feature was not observed within the first 50 centimeters below the soil surface.

c Soil texture was determined for each of the 5 subplots. Texture classes were CL $=c 1 a y 10 a m$, SiL $=$ silt loam, $L=10 a m$, and $S L=$ sandy loam (or sand). For each plot, if the same texture class was recorded on at least 4 of the subplots, then that texture class is reported for the plot, otherwise a range of texture classes is indicated.

d The mineral fraction $>2 \mathrm{~mm}$ diameter was classed as coarse fragments. Coarse fragment content was recorded as very $10 w$ (VL < 15 percent). low (15 percent < L < 30 percent). moderate ( 30 percent < $\mathrm{M}<60$ percent), or high (H>60 percent). 


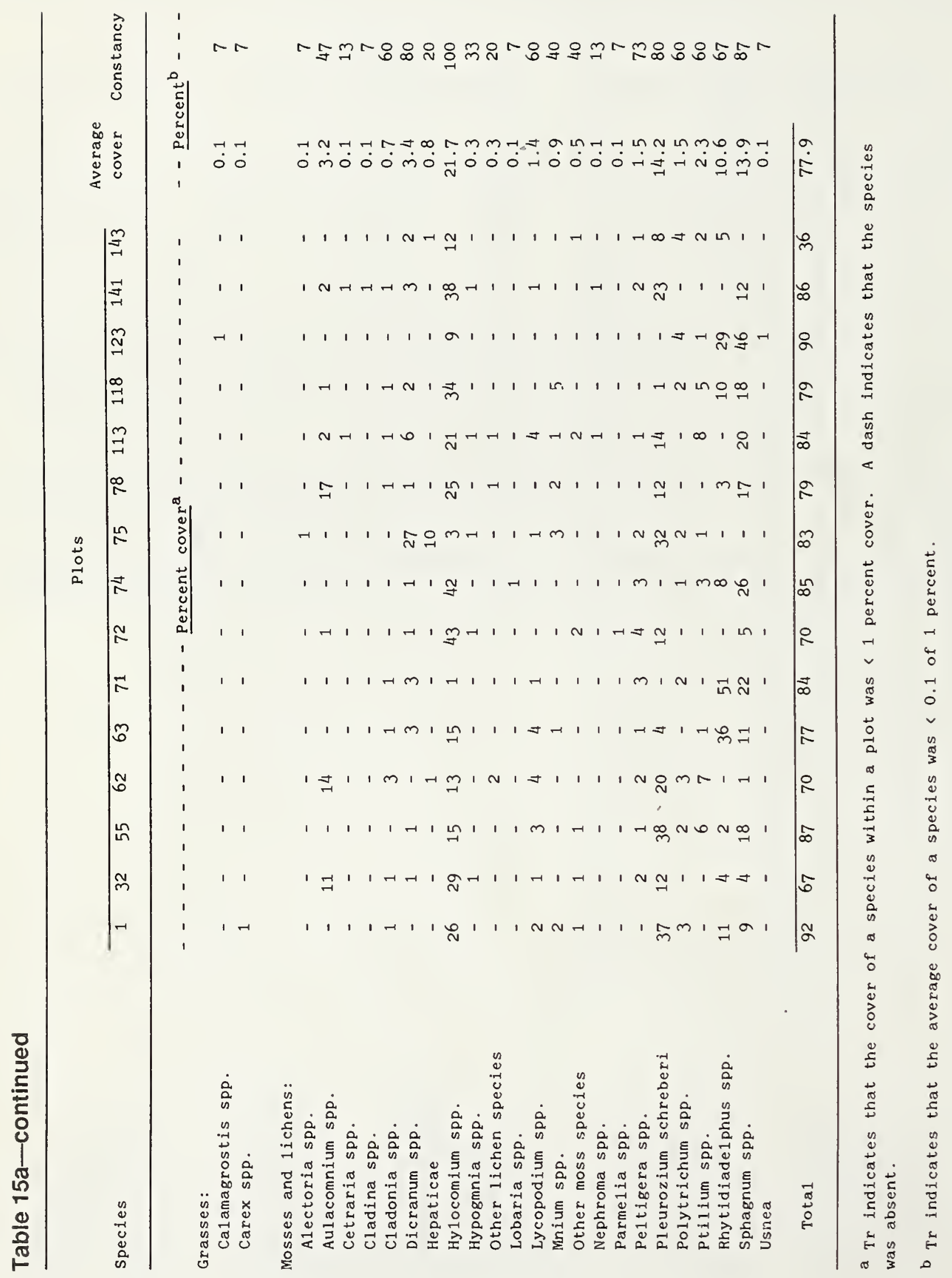


Table 15b-Site characteristics of Kenai vegetation plots belonging to the Closed Picea $\times$ Iutzii-Tsuga mertensiana/Menziesia ferruginea/Cornus canadensis/Sphagnum spp. TWINSPAN subset ${ }^{*} 1000$

\begin{tabular}{|c|c|c|c|c|c|c|c|}
\hline Plot & Elevation & $\begin{array}{l}\text { Principal } \\
\text { covera }\end{array}$ & Closure $\mathrm{b}^{\mathrm{b}}$ & $\begin{array}{l}\text { Stand } \\
\text { age }\end{array}$ & $\begin{array}{l}\text { Slope } \\
\text { position }\end{array}$ & Slope & Aspect \\
\hline & Meters & & & Years & & Percent & \\
\hline 1 & 213.4 & Conifer & Closed & 138 & Mid & 66.0 & $\mathrm{NW}$ \\
\hline 32 & 213.4 & Mixed & Closed & 63 & Mid & 68.4 & NE \\
\hline 55 & 182.9 & Conifer & Closed & 108 & Mid & 18.2 & NW \\
\hline 62 & 274.3 & Conifer & Closed & 47 & Mid & 33.0 & NE \\
\hline 63 & 213.4 & Conifer & Closed & 150 & Mid & 8.2 & SW \\
\hline 71 & 274.3 & Conifer & Closed & 95 & Mid & 43.0 & NW \\
\hline 72 & 213.4 & Conifer & Closed & 97 & Mid & 34.4 & $\mathrm{SE}$ \\
\hline 74 & $335 \cdot 3$ & Conifer & Closed & 155 & Mid & 19.8 & $\mathrm{SE}$ \\
\hline 75 & 457.2 & Conifer & Open & 105 & Mid & 20.6 & $\mathrm{NW}$ \\
\hline 78 & 304.8 & Conifer & Closed & 225 & Mid & 29.6 & $\mathrm{NE}$ \\
\hline 113 & 121.9 & Conifer & Closed & 113 & Mid & 38.8 & $\mathrm{NW}$ \\
\hline 118 & 213.4 & Conifer & Closed & 238 & Mid & 45.0 & $\mathrm{NW}$ \\
\hline 123 & 213.4 & Conifer & Closed & 188 & Mid & 14.4 & $\mathrm{NW}$ \\
\hline 141 & 243.8 & Conifer & Closed & 124 & Mid & 5.2 & NW \\
\hline 143 & 61.0 & Hardwood & Closed & 49 & Mid & 11.2 & SW \\
\hline
\end{tabular}

a A stand was classified as conifer if coniferous overstory trees contributed at least 75 percent of tree cover, and similarly for hardwoods. A stand was classified as mixed if neither overstory conifers nor hardwoods contributed at 1 east 75 percent of tree cover.

b A stand was classified as closed, open, or woodland if overstory tree cover was at least 60,25 , or 10 percent, respectively. Stands with< 10 percent cover were considered to be nonforest land.

c Stand age was calculated as the average of as many as 6 coniferous site trees. Site trees were individuals that had maintained a dominant or codominant canopy position for most of their lives. When possible, site trees were selected from those trees included in the variable-radius plots. If an insufficient number of site trees was obtained from the variable-radius plots, then additional neighboring trees meeting the site tree criterion were selected if possible.

d Possible values for slope (topographic) position were flat, low(er slope), mid(slope), upper (slope), and rolling (terrain).

e Possible values for aspect are the cardinal compass directions (N, S, E, and W) or combinations (for example, NW, SE). 
Table $15 \mathrm{c}$-Soil characteristics of Kenai vegetation plots belonging to the Closed Picea $\times$ Iutzii-Tsuga mertensiana/Menziesia ferruginea/Cornus canadensis/Sphagnum spp. TWINSPAN subset *1000

\begin{tabular}{|c|c|c|c|c|c|c|c|c|c|}
\hline \multirow[b]{2}{*}{ Plot } & \multicolumn{6}{|c|}{ Depth of: ${ }^{a}$} & \multicolumn{3}{|c|}{ Top mineral horizon } \\
\hline & $\begin{array}{l}\text { Impervious } \\
\text { layerb }\end{array}$ & $\begin{array}{l}\text { Saturated } \\
\text { soilb }\end{array}$ & $\begin{array}{l}\text { Root } \\
\text { depth }\end{array}$ & $\begin{array}{l}\text { Moss } \\
\text { layer }\end{array}$ & $\begin{array}{l}\text { Fibrous } \\
\text { organic }\end{array}$ & $\begin{array}{l}\text { Decomposed } \\
\text { organic }\end{array}$ & Texture ${ }^{c}$ & $\begin{array}{l}\text { Coarse } \\
\text { fragments }\end{array}$ & Deptha \\
\hline & $-\ldots-\cdots$ & $-\ldots-\cdots$ & - Cent & imeters & $-\cdots-$ & $-\cdots-\cdots$ & & & $\underline{\mathrm{Cm}}$ \\
\hline 1 & 51 & - & 26 & 10 & 31 & 42 & SiL-L & VL & 47 \\
\hline 32 & - & - & 30 & 2 & 8 & 15 & SiL-L & $\mathrm{VL}-\mathrm{H}$ & 40 \\
\hline 55 & - & - & 21 & 2 & 6 & 9 & SiL & $V L-L$ & 25 \\
\hline 62 & - & - & 16 & 2 & 6 & 19 & SiL-SL & $\mathrm{M}-\mathrm{H}$ & 28 \\
\hline 63 & 73 & 68 & 22 & 6 & 13 & 20 & SiL & VL & 34 \\
\hline 71 & - & - & 21 & 3 & 13 & 17 & CL-SiL & VL & 29 \\
\hline 72 & - & - & 26 & 5 & 14 & 19 & SiL & VL & 30 \\
\hline 74 & 87 & - & 20 & 5 & 10 & 20 & SiL-SL & VL & 34 \\
\hline 75 & - & - & 23 & 2 & 5 & 13 & SL & VL-L & 42 \\
\hline 78 & - & - & 26 & 3 & 9 & 15 & SiL & VL & 40 \\
\hline 113 & 84 & - & 26 & 4 & 19 & 25 & SiL & VL & 40 \\
\hline 118 & 40 & 82 & 22 & 2 & 7 & 10 & SiL & VL & 30 \\
\hline 123 & 86 & - & 32 & 9 & 15 & 20 & SiL & VL & 37 \\
\hline 141 & - & - & 19 & 4 & 12 & 17 & SiL-SL & VL & 49 \\
\hline 143 & - & - & 14 & 1 & 4 & 8 & SL & VL & 20 \\
\hline
\end{tabular}

a Al depths were relative to the top of the moss layer on the soil surface.

b A dash indicates that a specific type of soil feature was not observed within the first 50 centimeters below the soil surface.

c Soil texture was determined for each of the 5 subplots. Texture classes were CL = clay loam, SiL = silt loam, $L=$ loam, $S L=$ sandy loam, and LS= loamy sand (or sand). For each plot, if the same texture class was recorded on at least 4 of the subplots, then that texture class is reported for the plot, otherwise a range of texture classes is indicated.

d The mineral fraction > $2 \mathrm{~mm}$ diameter was classed as coarse fragments. Coarse fragment content was recorded as very low (VL < 15 percent), low (15 percent < $\mathrm{L}<30$ percent), moderate ( 30 percent \& 360 percent), or high ( $\mathrm{H}>60$ percent). 


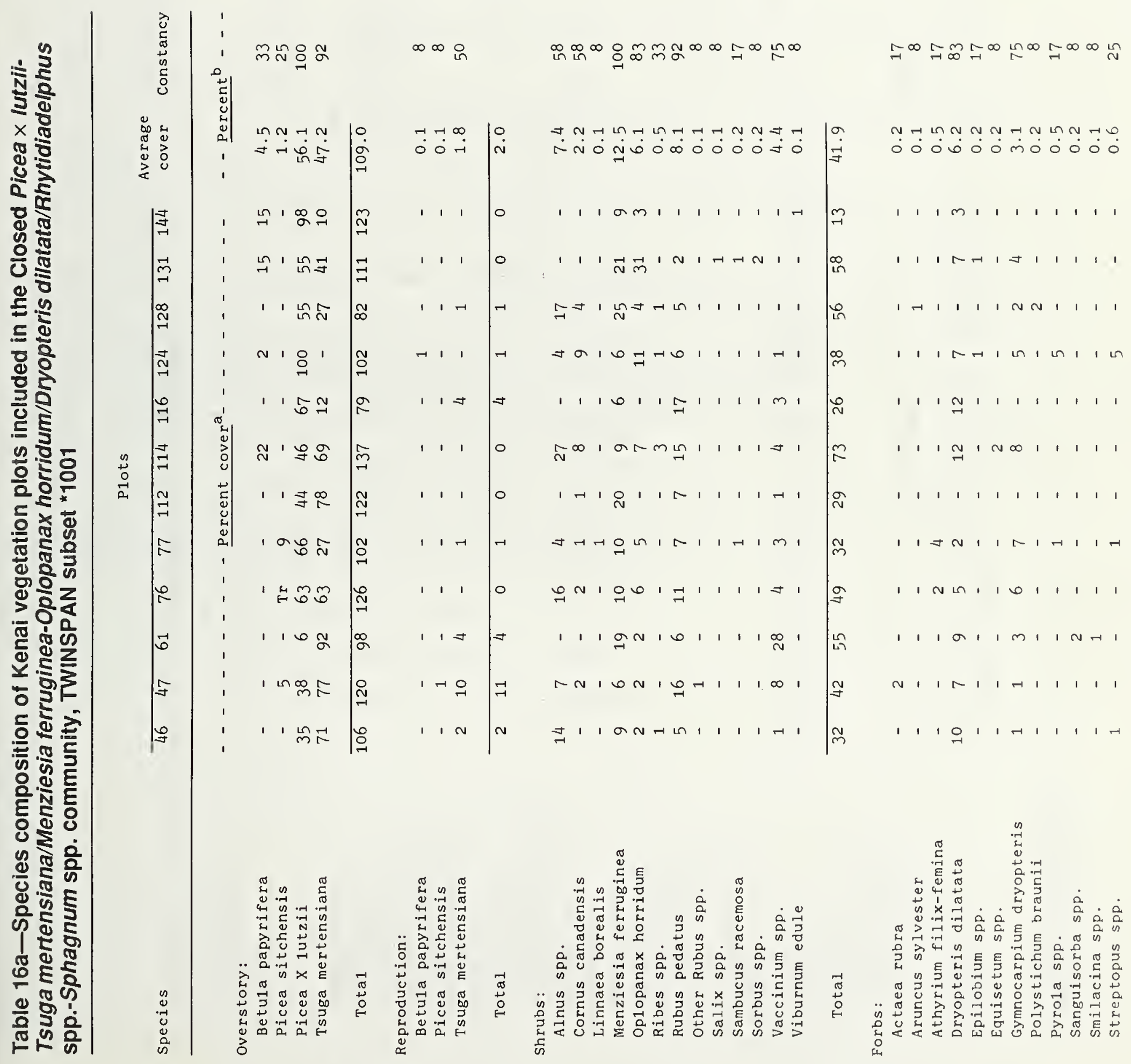




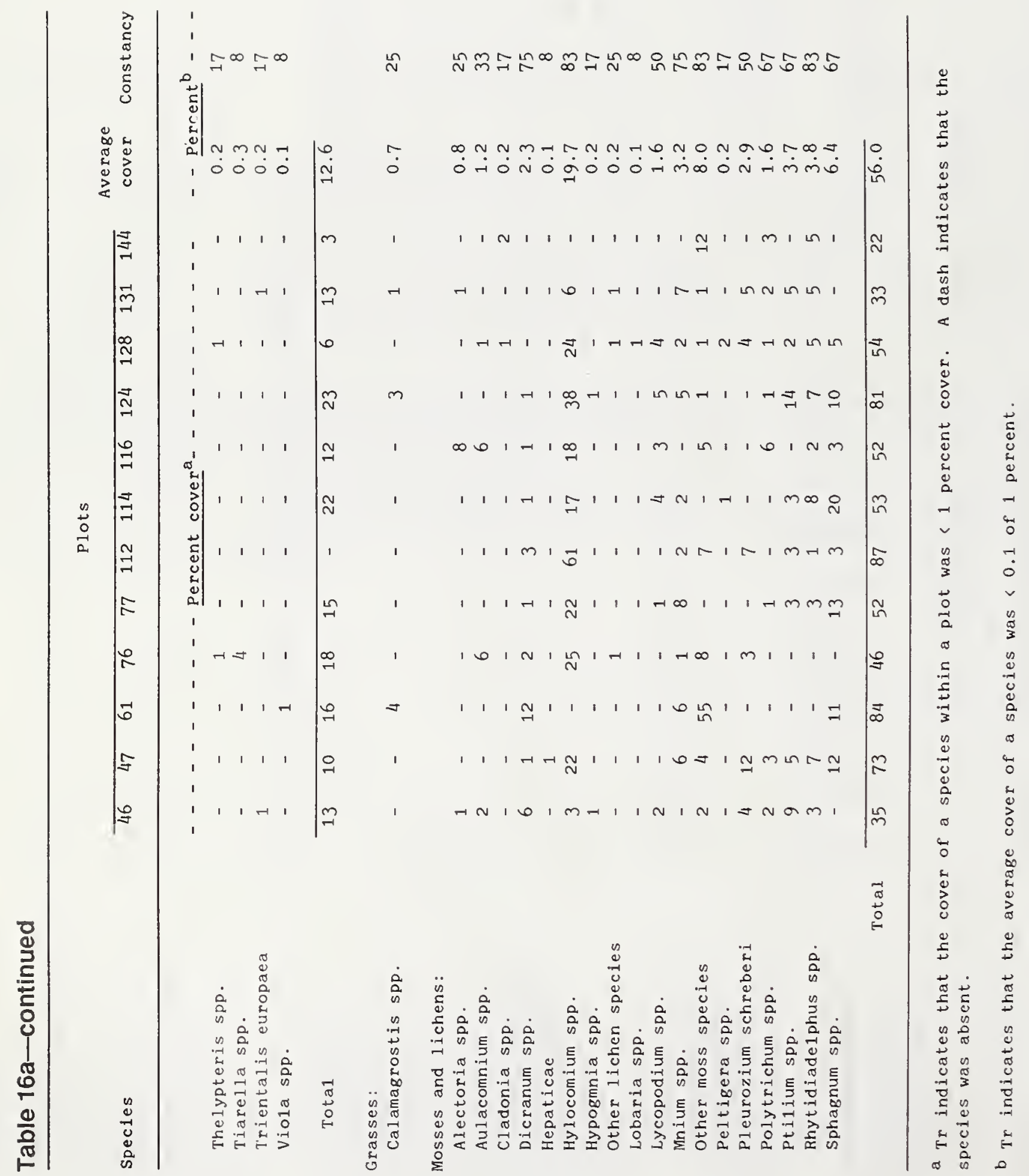


Table $16 \mathrm{~b}-$ Site characteristics of Kenai vegetation plots belonging to the Closed Picea $\times$ lutzii-Tsuga mertensiana/Menziesia ferrugineaOplopanax horridum/Dryopteris dilatata/Rhytidiadelphus spp.Sphagnum spp. community, TWINSPAN subset *1001

\begin{tabular}{|c|c|c|c|c|c|c|c|}
\hline Plot & Elevation & $\begin{array}{l}\text { Principal } \\
\text { cover }\end{array}$ & Closure ${ }^{b}$ & $\begin{array}{l}\text { Stand } \\
\text { age }\end{array}$ & $\begin{array}{l}\text { Slope } \\
\text { position }\end{array}$ & Slope & Asp \\
\hline & Meters & & & Years & & Percent & \\
\hline 46 & 426.7 & Conifer & Closed & 102 & Mid & 33.4 & SW \\
\hline 47 & 182.9 & Conifer & Closed & 227 & Mid & 44.0 & SE \\
\hline 61 & 213.4 & Conifer & Closed & 185 & Mid & 28.6 & SE \\
\hline 76 & 304.8 & Conifer & Closed & 158 & Mid & 32.2 & SW \\
\hline 77 & 213.4 & Conifer & Closed & 114 & Mid & 22.6 & SW \\
\hline 112 & 152.4 & Conifer & Closed & 230 & Mid & 54.6 & SE \\
\hline 114 & 243.8 & Conifer & Closed & 184 & Mid & 12.6 & NW \\
\hline 116 & 304.8 & Conifer & Closed & 127 & Mid & 86.8 & $N W$ \\
\hline 124 & 152.4 & Conifer & Closed & 128 & Low & 3.2 & NW \\
\hline 128 & 274.3 & Conifer & Closed & 128 & Mid & 60.2 & $\mathrm{SE}$ \\
\hline 131 & 304.8 & Conifer & Open & 55 & Mid & 44.2 & NE \\
\hline 144 & 91.4 & Conifer & Closed & 131 & Mid & 60.0 & $\mathrm{SE}$ \\
\hline
\end{tabular}

a A stand was classified as conifer if coniferous overstory trees contributed at least 75 percent of tree cover, and similarly for hardwoods. A stand was classified as mixed if neither overstory conifers nor hardwoods contributed at 1 east 75 percent of tree cover.

b A stand was classified as closed, open, or woodland if overstory tree cover was at least 60,25 , or 10 percent, respectively. Stands with < 10 percent cover were considered to be nonforest 1 and.

c Stand age was calculated as the average of as many as 6 coniferous site trees. Site trees were individuals that had maintained a dominant or codominant canopy position for most of their lives. When possible, site trees were selected from those trees included in the variable-radius plots. If an insufficient number of site trees was obtained from the variable-radius plots, then additional neighboring trees meeting the site tree criterion were selected if possible.

d Possible values for slope (topographic) position were flat, low(er slope), mid(slope), upper (slope), and rolling (terrain).

e Possible values for aspect are the cardinal compass directions (N, $S, E$, and $W$ ) or combinations (for example, NW, SE). 
Table 16c-Soil characteristics of Kenai vegetation plots belonging to the Closed Picea x lutzii-Tsuga mertensiana/Menziesia ferruginea-Oplopanax horridum/ Dryopteris dilatata/Rhytidiadelphus spp.-Sphagnum spp. community, TWINSPAN subset *1001

\begin{tabular}{|c|c|c|c|c|c|c|c|c|c|}
\hline \multirow[b]{2}{*}{ Plot } & \multicolumn{6}{|c|}{ Depth of: ${ }^{a}$} & \multicolumn{3}{|c|}{ Top mineral horizon } \\
\hline & $\begin{array}{l}\text { Impervious } \\
\text { layer }\end{array}$ & $\begin{array}{l}\text { Saturated } \\
\text { soil b }\end{array}$ & $\begin{array}{l}\text { Root } \\
\text { depth }\end{array}$ & $\begin{array}{l}\text { Moss } \\
\text { layer }\end{array}$ & $\begin{array}{l}\text { Fibrous } \\
\text { organic }\end{array}$ & $\begin{array}{l}\text { Decomposed } \\
\text { organic }\end{array}$ & Texture ${ }^{c}$ & $\begin{array}{l}\text { Coarse } \\
\text { fragments }\end{array}$ & Deptha \\
\hline & $-\cdots-\cdots$ & $-\ldots$ & - Cent & imeters & --- & $-\ldots$ & & & $\underline{\mathrm{Cm}}$ \\
\hline 46 & - & - & 24 & 3 & 9 & 16 & SiL-SL & $\mathrm{VL}-\mathrm{H}$ & 39 \\
\hline 47 & - & - & 23 & 5 & 8 & 10 & SiL & $V L-M$ & 22 \\
\hline 61 & - & 84 & 18 & 2 & 6 & 11 & SiL-L & VL & 23 \\
\hline 76 & 85 & - & 26 & 4 & 9 & 12 & SiL-L & VL & 29 \\
\hline 77 & - & - & 25 & 10 & 18 & 23 & SiL & $V L-M$ & 39 \\
\hline 112 & - & - & 20 & 4 & 8 & 13 & SiL & VL & 31 \\
\hline 114 & - & 75 & 23 & 2 & 9 & 22 & SiL-LS & VL-M & 36 \\
\hline 116 & 23 & - & 18 & 1 & 7 & 18 & $\mathrm{CL}$ & VL & 23 \\
\hline 124 & - & - & 14 & 7 & 11 & 14 & LS & $\mathrm{L}-\mathrm{H}$ & 28 \\
\hline 128 & - & - & 18 & 4 & 15 & 26 & $S i L-L$ & VL & 44 \\
\hline 131 & 43 & - & 21 & 2 & 13 & 16 & SL & VL & 20 \\
\hline 144 & 87 & - & 32 & 3 & 11 & 19 & SiL & $\mathrm{VL}-\mathrm{H}$ & 40 \\
\hline
\end{tabular}

a All depths were relative to the top of the moss layer on the soil surface.

b A dash indicates that a specific type of soil feature was not observed within the first 50 centimeters below the soil surface.

c Soil texture was determined for each of the 5 subplots. Texture classes were CL $=$ clay loam, SiL = silt loam, L = loam, SL = sandy loam, and LS = loamy sand (or sand). For each plot, if the same texture class was recorded on at least 4 of the subplots, then that texture class is reported for the plot, otherwise a range of texture classes is indicated.

d The mineral fraction $>2 \mathrm{~mm}$ diameter was classed as coarse fragments. Coarse fragment content was recorded as very low (VL < 15 percent), low ( 15 percent < L 30 percent), moderate i 30 percent< $M<60$ percent), or high (H $>60$ percent). 
Table 17a-Species composition of Kenai vegetation plots included in the Closed Picea sitchensis/Oplopanax horridum-Rubus pedatus/Dryopteris dilatata-Gymnocarpium dryopteris/Mnium spp.-Rhytidiadelphus spp. community, TWINSPAN subset ${ }^{*} 101$

P1ots

$\begin{array}{llllllllll}\text { Species } & 2 & 3 & 4 & 93 & 107 & 110 & 111 & 125 & \text { Average cover Constancy }\end{array}$

Overstory:

Picea glauca

Picea sitchensis

Picea X 1utzii

Tsuga mertensiana

Total

\begin{tabular}{|c|c|c|c|c|c|c|c|c|c|}
\hline - & - & - & - & - & $\mathrm{Tr}$ & - & - & $\mathrm{Tr}$ & 12 \\
\hline 100 & 100 & $\mathrm{Tr}$ & - & 18 & 100 & 100 & - & 52.3 & 75 \\
\hline - & - & 100 & 100 & 8 & - & - & 95 & 25.4 & 50 \\
\hline - & - & - & - & 70 & - & - & 15 & 10.6 & 25 \\
\hline
\end{tabular}

Reproduction:

Picea sitchensis

Picea X lutzii

Tsuga mertensiana

Total

\begin{tabular}{lllllllll}
\hline 100 & 100 & 100 & 100 & 96 & 100 & 100 & 110 & 100.7
\end{tabular}

Shrubs:

A1nus spp.

Cornus canadensis

Cornus suecica

Linnaea borea1is

Menziesia ferruginea

Oplopanax horridum

Rubus pedatus

Other Rubus species

Sambucus racemosa

Vaccinium spp.

Viburnum edu1e

Total

Forbs:

Athyrium filix-femina

Caltha spp.

Dryopteris dilatata

Equisetum spp.

Gymnocarpium dryopteris

Listera cordata

Moneses unif 1 ora

Pyrola spp.

Streptopus spp.

The1ypteris spp.

Tiare11a spp.

Tota1

\begin{tabular}{llllllllll}
- & 3 & - & - & - & - & 2 & - & 0.6 & 25 \\
- & - & - & - & 4 & - & - & 1 & 0.6 & 25 \\
- & - & - & - & 9 & - & - & - & 1.1 & 12 \\
\hline 0 & 3 & 0 & 0 & 13 & 0 & 2 & 1 & 2.4
\end{tabular}

$\begin{array}{rrrrrrrrrr}- & - & - & 3 & - & - & 4 & 3 & 1.2 & 37 \\ - & - & - & - & 3 & 3 & 2 & 3 & 1.4 & 50 \\ - & - & - & - & - & 1 & - & - & 0.1 & 12 \\ 1 & - & - & - & - & - & - & - & 0.1 & 12 \\ 1 & 2 & - & 1 & 3 & 11 & - & - & 2.2 & 62 \\ 16 & 36 & 28 & 5 & 3 & 16 & 3 & 29 & 17.0 & 100 \\ 12 & 42 & 10 & 18 & 7 & 20 & 24 & 15 & 18.5 & 100 \\ - & 2 & - & - & 5 & - & 1 & - & 0.7 & 37 \\ - & - & 1 & - & - & - & - & - & 0.1 & 12 \\ 2 & 7 & 7 & - & 17 & 20 & 64 & 1 & 14.7 & 87 \\ - & - & 1 & - & - & - & - & - & 0.1 & 12\end{array}$

\begin{tabular}{lllllllll}
\hline 32 & 89 & 47 & 27 & 38 & 71 & 98 & 51 & 56.6
\end{tabular}

Grasses :

Ca1 amagrostis spp.

$\begin{array}{rrrrrrrrrr}20 & - & - & - & - & - & 1 & - & 2.6 & 25 \\ - & - & - & - & 1 & - & - & - & 0.1 & 12 \\ 4 & 13 & 31 & - & 22 & 40 & - & 12 & 15.2 & 75 \\ - & - & - & - & - & 1 & - & - & 0.1 & 12 \\ 31 & 30 & 21 & 2 & - & 17 & 9 & 16 & 15.7 & 87 \\ 1 & 2 & - & - & 4 & - & - & - & 0.9 & 37 \\ 1 & 3 & - & 5 & - & - & - & - & 1.1 & 37 \\ - & - & - & - & 1 & - & - & - & 0.1 & 12 \\ - & - & 2 & - & 2 & 1 & - & 2 & 0.9 & 50 \\ - & - & - & 49 & - & - & - & - & 6.1 & 12 \\ 7 & 16 & 6 & - & 11 & - & 1 & 1 & 5.2 & 75\end{array}$

Mosses and 1 ichens:

Au1acomnium spp.

Cladina spp.

C1adonia spp.

Dicranum spp.

Hepaticae

Hylocomium spp.

Hypogmnia spp.

Other 1 ichen species

Lobaria spp.

\begin{tabular}{lllllllll}
\hline 64 & 64 & 60 & 56 & 41 & 59 & 11 & 31 & 48.2
\end{tabular}

See footnotes at and of tab1e. 


\begin{tabular}{|c|c|c|c|c|c|c|c|c|c|c|}
\hline \multirow[b]{2}{*}{ Species } & \multicolumn{8}{|c|}{ P1ots } & \multirow{2}{*}{$\begin{array}{l}\text { Average } \\
\text { cover }\end{array}$} & \multirow[b]{2}{*}{ Constancy } \\
\hline & 2 & 3 & 4 & 93 & 107 & 110 & 111 & 125 & & \\
\hline & -- & -- & -- & erce & nt $c o$ & ver $^{a}$ & $-\cdots$ & -- & $--\underline{P e}$ & cent $^{b}--$ \\
\hline \multicolumn{11}{|l|}{ Mosses and 1ichens: } \\
\hline Lycopodium spp. & 1 & 8 & 5 & - & - & 8 & 1 & 1 & 3.0 & 75 \\
\hline Mnium spp. & 45 & 10 & 22 & 25 & 5 & 9 & - & 20 & 17.0 & 87 \\
\hline Other moss species & 6 & 3 & 1 & 17 & 2 & 9 & 5 & 1 & 5.5 & 100 \\
\hline P1eurozium schreberi & 3 & - & 7 & 5 & - & 1 & - & 19 & 4.4 & 62 \\
\hline Po1ytrichum spp. & - & - & 4 & - & 1 & 2 & - & - & 0.9 & 37 \\
\hline Ptilium spp. & - & - & - & - & - & 4 & - & - & 0.5 & 12 \\
\hline Rhytidiade1phus spp. & 15 & 57 & 35 & 4 & 40 & - & 68 & 22 & 30.0 & 87 \\
\hline Sphagnum spp. & - & - & - & - & 5 & 12 & - & - & 2.1 & 25 \\
\hline Usnea spp. & - & - & - & - & - & - & 1 & - & 0.1 & 12 \\
\hline Tota1 & 94 & 103 & 88 & 68 & 76 & 74 & 91 & 78 & 84.0 & \\
\hline
\end{tabular}

a $\mathrm{Tr}$ indicates that the cover of a species within a plot was $<1$ percent cover.

A dash indicates that the species was absent.

b $\mathrm{Tr}$ indicates that the average cover of a species was $<0.1$ of 1 percent. 
Table 17b-Site characteristics of Kenai vegetation plots belonging to the Closed Picea sitchensis/Oplopanax horridum-Rubus pedatus/Dryopteris dilatata-Gymnocarpium dryopteris/Mnium spp.-Rhytidiadelphus spp. community, TWINSPAN subset *101

\begin{tabular}{|c|c|c|c|c|c|c|c|}
\hline Plot & Elevation & $\begin{array}{l}\text { Principal } \\
\text { cover }^{\mathrm{a}}\end{array}$ & Closure ${ }^{b}$ & $\begin{array}{l}\text { Stand } \\
\text { age }\end{array}$ & $\begin{array}{l}\text { Slope } \\
\text { position }\end{array}$ & Slope & Aspect \\
\hline & Meters & & & Years & & Percent & \\
\hline 2 & 213.4 & Conifer & Closed & 137 & Mid & 40.0 & NW \\
\hline 3 & 30.5 & Conifer & Open & 137 & Mid & 18.2 & SW \\
\hline 4 & 30.5 & Conifer & Closed & 89 & Mid & 4.8 & SW \\
\hline 93 & 243.8 & Conifer & Closed & 130 & Mid & 42.2 & NW \\
\hline 107 & 91.4 & Conifer & Open & 215 & Mid & 48.0 & NE \\
\hline 110 & 61.0 & Conifer & Closed & 143 & Mid & 41.2 & SW \\
\hline 111 & 30.5 & Conifer & Closed & 139 & Flat & 2.4 & None \\
\hline 125 & 182.9 & Conifer & Closed & 153 & Low & 3.2 & $\mathrm{NW}$ \\
\hline
\end{tabular}

a A stand was classified as conifer if coniferous overstory trees contributed at least 75 percent of tree cover, and similarly for hardwoods. A stand was classified as mixed if neither overstory conifers nor hardwoods contributed at 1 east 75 percent of tree cover.

b A stand was classified as closed, open, or woodland if overstory tree cover was at least 60,25 , or 10 percent, respectively. Stands with < 10 percent cover were considered to be nonforest land.

c stand age was calculated as the average of as many as 6 coniferous site trees. Site trees were individuals that had maintained a dominant or codominant canopy position for most of their lives. When possible, site trees were selected from those trees included in the variable-radius plots. If an insufficient number of site trees was obtained from the variable-radius plots, then additional neighboring trees meeting the site tree criterion were selected if possible.

d Possible values for slope (topographic) position were flat, low(er slope), mid(slope), upper (slope), and rolling (terrain).

e Possible values for aspect are the cardinal compass directions (N, S, E, and W) or combinations (for example, NW, SE). 
Table 17c-Soil characteristics of Kenai vegetation plots belonging to the Closed Picea sitchensis/Oplopanax horridum-Rubus pedatus/Dryopteris dilatata-Gymnocarpium dryopteris/Mnium spp.-Rhytidiadelphus spp. community, TWINSPAN subset *101

\begin{tabular}{|c|c|c|c|c|c|c|c|c|c|}
\hline \multirow[b]{2}{*}{ Plot } & \multicolumn{6}{|c|}{ Depth of : $a$} & \multicolumn{3}{|c|}{ Top mineral horizon } \\
\hline & $\begin{array}{l}\text { Impervious } \\
\text { layerb }\end{array}$ & $\begin{array}{l}\text { Saturated } \\
\text { soil b }\end{array}$ & $\begin{array}{l}\text { Root } \\
\text { depth }\end{array}$ & $\begin{array}{l}\text { Moss } \\
\text { layer }\end{array}$ & $\begin{array}{l}\text { Fibrous } \\
\text { organic }\end{array}$ & $\begin{array}{l}\text { Decomposed } \\
\text { organic }\end{array}$ & Texture ${ }^{c}$ & $\begin{array}{l}\text { Coarse } \\
\text { fragments }\end{array}$ & Depth ${ }^{2}$ \\
\hline & ----- & ---- & - Cen & imeters & ---- & ----- & & & $\underline{\mathrm{Cm}}$ \\
\hline 2 & - & - & 18 & 1 & 2 & 4 & SiL & VL & 29 \\
\hline 3 & - & 83 & 21 & 2 & 6 & 11 & SiL & VL & 20 \\
\hline 4 & - & - & 26 & 6 & 9 & 11 & $\mathrm{SiL}$ & VL & 22 \\
\hline 93 & 71 & - & 16 & 2 & 6 & 11 & SiL & VL & 32 \\
\hline 107 & 84 & - & 22 & 2 & 5 & 10 & $\mathrm{~L}$ & $\mathrm{VL}-\mathrm{M}$ & 37 \\
\hline 110 & - & - & 17 & 2 & 11 & 19 & $\mathrm{~L}-\mathrm{LS}$ & VL & 38 \\
\hline 111 & - & - & 11 & 2 & 6 & 8 & SiL-LS & VL & 15 \\
\hline 125 & - & - & 14 & 2 & 5 & 8 & SL-LS & $\mathrm{VL}-\mathrm{M}$ & 20 \\
\hline
\end{tabular}

a All depths were relative to the top of the moss layer on the soil surface.

b A dash indicates that a specific type of soil feature was not observed within the first 50 centimeters below the soil surface.

C Soil texture was determined for each of the 5 subplots. Texture classes were CL = clay loam, $\mathrm{SiL}=$ silt loam, $\mathrm{L}=$ loam, $\mathrm{SL}=$ sandy loam, and LS = loamy sand (or sand). For each plot, if the same texture class was recorded on at least 4 of the subplots, then that texture class is reported for the plot, otherwise a range of texture classes is indicated.

d The mineral fraction > $2 \mathrm{~mm}$ diameter was classed as coarse fragments. Coarse fragment content was recorded as very low (VL < 15 percent), low (15 percent < $L$ < 30 percent), moderate ( 30 percent < $M$ < 60 percent), or high $(H>60$ percent $)$. 
Table 18a-Species composition of Kenai vegetation plots included in the Open Picea $\times$ Iutzii-Populus trichocarpa/Alnus spp.-Oplopanax horridum/Dryopteris dilatata community, TWINSPAN subset *11

\begin{tabular}{|c|c|c|c|c|c|c|c|}
\hline \multirow[b]{2}{*}{ SPECIES } & \multicolumn{5}{|c|}{ Plots } & \multirow{2}{*}{$\begin{array}{l}\text { Average } \\
\text { cover }\end{array}$} & \multirow[b]{2}{*}{ Constancy } \\
\hline & 23 & 31 & 54 & 73 & 99 & & \\
\hline & - & Perc & ent $c$ & ver ${ }^{\mathrm{a}}$ & -- & - - Per & $\operatorname{cent}^{b_{-}}-$ \\
\hline \multicolumn{8}{|l|}{ Overstory: } \\
\hline Betula papyrifera & - & - & - & - & 6 & 1.2 & 20 \\
\hline Picea glauca & - & 55 & - & $\operatorname{Tr}$ & - & 11.1 & 40 \\
\hline Picea sitchensis & - & - & 16 & - & - & 3.2 & 20 \\
\hline Picea X lutzii & 33 & - & - & 34 & 99 & 33.2 & 60 \\
\hline Populus trichocarpa & 6 & 5 & 82 & - & - & 18.6 & 60 \\
\hline Tsuga mertensiana & - & - & - & 34 & - & 6.8 & 20 \\
\hline Total & 39 & 60 & 98 & 68 & 105 & 74.0 & \\
\hline \multicolumn{8}{|l|}{ Shrubs : } \\
\hline Alnus spp. & 10 & 59 & 61 & 6 & 10 & 29.2 & 100 \\
\hline Linnaea borealis & - & - & - & - & 4 & 0.8 & 20 \\
\hline Menziesia ferruginea & - & - & - & 1 & - & 0.2 & 20 \\
\hline Oplopanax horridum & 10 & 12 & 46 & 18 & 11 & 19.4 & 100 \\
\hline Ribes spp. & - & 3 & - & 5 & - & 1.6 & 40 \\
\hline Rubus pedatus & - & - & - & 9 & 13 & 4.4 & 40 \\
\hline Sambucus racemosa & 1 & 2 & 1 & 5 & 3 & 2.4 & 100 \\
\hline Total & 21 & 76 & 108 & 44 & 41 & 58.0 & \\
\hline \multicolumn{8}{|l|}{ Forbs : } \\
\hline Athyrium filix-femina & - & - & 5 & - & 1 & 1.2 & 40 \\
\hline Dryopteris dilatata & - & 22 & 5 & 38 & 37 & 20.4 & 80 \\
\hline Epilobium spp. & - & - & - & - & 3 & 0.6 & 20 \\
\hline Equisetum spp. & - & - & - & - & 16 & 3.2 & 20 \\
\hline Galium spp. & - & 1 & 1 & - & - & 0.4 & 40 \\
\hline Gymnocarpium dryopteris & - & 18 & 10 & - & 18 & 9.2 & 60 \\
\hline Sanguisorba spp. & - & - & - & - & 2 & 0.4 & 20 \\
\hline Streptopus spp. & - & - & - & 1 & - & 0.2 & 20 \\
\hline Trientalis europaea & - & 1 & - & 5 & - & 1.2 & 40 \\
\hline Total & 0 & 42 & 21 & 44 & 77 & 36.8 & \\
\hline \multicolumn{8}{|l|}{ Grasses: } \\
\hline Calamagrostis spp. & - & - & - & - & 14 & 2.8 & 20 \\
\hline \multicolumn{8}{|l|}{ Mosses and lichens: } \\
\hline Aulacomnium spp. & - & - & - & 10 & 1 & 2.2 & 40 \\
\hline Dicranum spp. & - & - & - & - & 1 & 0.2 & 20 \\
\hline Hylocomium spp. & - & - & 1 & - & - & 0.2 & 20 \\
\hline Hypnum spp. & - & - & - & - & 4 & 0.8 & 20 \\
\hline Hypogmnia spp. & - & - & - & - & 2 & 0.4 & 20 \\
\hline Other lichen species & - & - & 1 & - & 1 & 0.4 & 40 \\
\hline Lycopodium spp. & - & - & - & 2 & 5 & 1.4 & 40 \\
\hline Mnium spp. & - & - & 2 & - & 32 & 6.8 & 40 \\
\hline Other moss species & - & - & 3 & 6 & 15 & 4.8 & 60 \\
\hline Pleurozium schreberi & - & - & - & - & 1 & 0.2 & 20 \\
\hline Rhytidiadelphus spp. & - & - & 2 & - & - & 0.4 & 20 \\
\hline Total & 0 & 0 & 9 & 18 & 62 & 17.8 & \\
\hline
\end{tabular}

a $\mathrm{Tr}$ indicates that the cover of a species within a plot was $<1$ percent cover. A dash indicates that the species was absent.

b $\mathrm{Tr}$ indicates that the average cover of a species was $<1$-tenth of one percent. 
Table $18 \mathrm{~b}-$ Site characteristics of Kenai vegetation plots belonging to the Open Picea $\times$ Iutzii-Populus trichocarpa/Alnus spp.-Oplopanax horridum/Dryopteris dilatata community, TWINSPAN subset *11

\begin{tabular}{|c|c|c|c|c|c|c|c|}
\hline Plot & Elevation & $\begin{array}{l}\text { Principal } \\
\text { cover }\end{array}$ & Closure ${ }^{b}$ & $\begin{array}{l}\text { Stand } \\
\text { age }\end{array}$ & $\begin{array}{l}\text { Slope } \\
\text { position }\end{array}$ & Slope & Aspect \\
\hline & Meters & & & Years & & Percent & \\
\hline 23 & 30.5 & Conifer & Woods & 69 & Mid & 15.4 & SW \\
\hline 31 & 304.8 & Conifer & Open & 178 & Mid & 4.6 & SW \\
\hline 54 & 61.0 & Hardwood & Open & 146 & Flat & 1.0 & None \\
\hline 73 & 396.2 & Conifer & Closed & 116 & Mid & 43.4 & SW \\
\hline 99 & 152.4 & Conifer & Closed & 140 & Flat & 5.8 & None \\
\hline
\end{tabular}

a A stand was classified as conifer if coniferous overstory trees contributed at least 75 percent of tree cover, and similarly for hardwoods. A stand was classified as mixed if neither overstory conifers nor hardwoods contributed at least 75 percent of tree cover.

b A stand was classified as closed, open, or woodland if overstory tree cover was at least 60,25 , or 10 percent, respectively. Stands with < 10 percent cover were considered to be nonforest land.

c stand age was calculated as the average of as many as 6 coniferous site trees. Site trees were individuals that had maintained a dominant or codominant canopy position for most of their lives. When possible, site trees were selected from those trees included in the variable-radius plots. If an insufficient number of site trees was obtained from the variable-radius plots, then additional neighboring trees meeting the site tree criterion were selected if possible.

d Possible values for slope (topographic) position were flat, low(er slope), mid(slope), upper (slope), and rolling (terrain).

e Possible values for aspect are the cardinal compass directions (N, S, E, and W) or combinations (for example, NW, SE). 
Table 18c-Soil characteristics of Kenai vegetation plots belonging to the Open Picea $\times$ Iutzii-Populus trichocarpa/Alnus spp.-Oplopanax horridum/Dryopteris dilatata community, TWINSPAN subset *11

\begin{tabular}{|c|c|c|c|c|c|c|c|c|c|}
\hline \multirow[b]{2}{*}{ P1ot } & \multicolumn{6}{|c|}{ Depth of : ${ }^{a}$} & \multicolumn{3}{|c|}{ Top mineral horizon } \\
\hline & $\begin{array}{l}\text { Impervious } \\
\text { layerb }\end{array}$ & $\begin{array}{l}\text { Saturated } \\
\text { soil b }\end{array}$ & $\begin{array}{l}\text { Root } \\
\text { depth }\end{array}$ & $\begin{array}{l}\text { Moss } \\
\text { layer }\end{array}$ & $\begin{array}{l}\text { Fibrous } \\
\text { organic }\end{array}$ & $\begin{array}{l}\text { Decomposed } \\
\text { organic }\end{array}$ & Texture ${ }^{c}$ & $\begin{array}{l}\text { Coarse } \\
\text { fragments }\end{array}$ & Deptha \\
\hline & $-\ldots$ & $-\ldots$ & - Cent & imeterś & --- & $-\cdots-$ & & & $\underline{\mathrm{Cm}}$ \\
\hline 23 & - & 83 & 54 & 0 & 10 & 18 & LS & $\mathrm{L}-\mathrm{M}$ & 47 \\
\hline 31 & - & 80 & 16 & 2 & 8 & 11 & SL-LS & VL-H & 30 \\
\hline 54 & - & - & 17 & 0 & 4 & 7 & CL-SiL & VL & 14 \\
\hline 73 & 59 & - & 17 & 2 & 7 & 14 & $\mathrm{CL}-\mathrm{L}$ & VL-M & 36 \\
\hline 99 & - & - & 14 & 3 & 8 & 12 & SiL & VL & 28 \\
\hline
\end{tabular}

a All depths were relative to the top of the moss layer on the soil surface.

b A dash indicates that a specific type of soil feature was not observed within the first 50 centimeters below the soil surface.

c Soil texture was determined for each of the 5 subplots. Texture classes were CL $=c l a y ~ l o a m$, SiL = silt loam, L = loam, SL = sandy loam, and LS = loamy sand (or sand). For each plot, if the same texture class was recorded on at least 4 of the subplots, then that texture class is reported for the plot, otherwise a range of texture classes is indicated.

d The mineral fraction $>2 \mathrm{~mm}$ diameter was classed as coarse fragments. Coarse fragment content was recorded as very low (VL < 15 percent), low (15 percent < $\mathrm{L}<30$ percent), moderate ( 30 percent < $\mathrm{M}<60$ percent), or high (H>60 percent). 
Reynolds, K.M. 1990. Preliminary classification of forest vegetation of the Kenai Peninsula, Alaska. Res. Pap. PNW-RP-424. Portland, OR: U.S. Department of Agriculture, Forest Service, Pacific Northwest Research Station. 67 p.

A total of 5,597 photo points was systematically located on 1:60,000-scale highaltitude photographs of the Kenai Peninsula. Alaska; photo interpretation was used to classify the vegetation at each grid position. Of the total grid points, 12.3 percent were classified as timberland; 129 photo points within the timberland class were randomly selected for field survey. The number of sample points visited in each of three forest cover types (conifer, broadleaf, and mixed conifer-broadleaf) was proportional to the frequency of the cover type in the photo sample. Two-way indicator species analysis (TWINSPAN) was used to develop a hierarchical classification of the forest communities observed on the peninsula. Brief descriptions are presented for the 11 recognized communities with a discussion of their relation to basic physiographic and edaphic characteristics.

Keywords: Vegetation classification, Kenai Peninsula, Alaska.

The Forest Service of the U.S. Department of Agriculture is dedicated to the principle of multiple use management of the Nation's forest resources for sustained yields of wood, water, forage, wildlife, and recreation. Through forestry research, cooperation with the States and private forest owners, and management of the National Forests and National Grasslands, it strives - as directed by Congress - to provide increasingly greater service to a growing Nation.

The U.S. Department of Agriculture is an Equal Opportunity Employer. Applicants for all Department programs will be given equal consideration without regard to age, race, color, sex, religion, (ir national origin.

Pacific Northwest Research Station

319 S.W. Pine St.

P.O. Box 3890

Portland, OR 97208-3890 


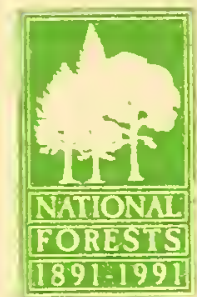

U.S. Department of Agriculture

Pacific Northwest Research Station

POSTAG.

319 S.W. Pine Street

P.O. Box 3890

USDA.FS

Portland, Oregon 97208

PERMIT NO

Official Business

Penalty for Private Use, $\$ 300$ 